(C) 2018 Elsevier B.V. . Elsevier requires authors posting their accepted manuscript to attach a noncommercial Creative Commons user license (CC-BY-NC-ND). https://www.elsevier.com/about/policies/ sharing\#definitions This manuscript version is made available under the CC-BY-NC-ND 4.0 license http:// creativecommons.org/licenses/by-nc-nd/4.0/ (Publisher journal website as of 14/4/2020)

\title{
Recent Advances in Ultraviolet and Deep-Ultraviolet Second-Order
} Nonlinear Optical Crystals

\author{
Chao Wu ${ }^{\text {a }}$, Gang Yang ${ }^{\text {a }}$, Mark G. Humphrey ${ }^{\mathrm{b}}$, Chi Zhang ${ }^{\mathrm{a} *}$ \\ ${ }^{a}$ China-Australia Joint Research Center for Functional Molecular Materials, School of Chemical Science and \\ Engineering, Tongji University, Shanghai 200092, P. R. China \\ ${ }^{b}$ Research School of Chemistry, Australian National University, Canberra, ACT 2601, Australia
}




\section{Contents}

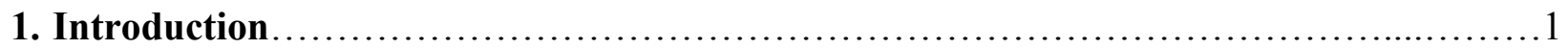

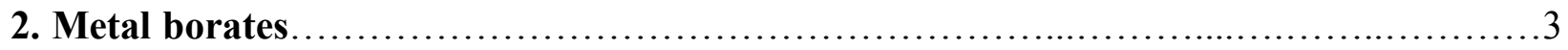

2.1 Metal borates without additional anions...................................... 4

2.2 Metal borates containing halides............................................ 10

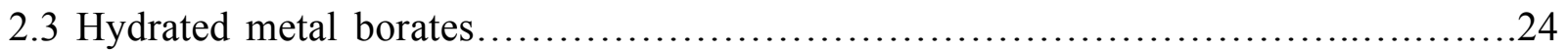

2.4 Metal borates with mixed anions........................................... 30

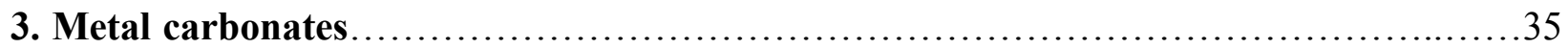

3.1 Metal carbonates without additional anions................................. 35

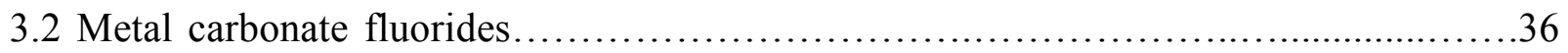

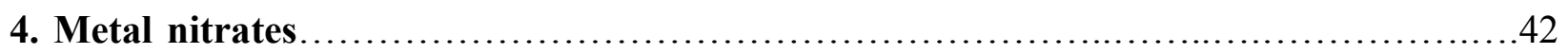

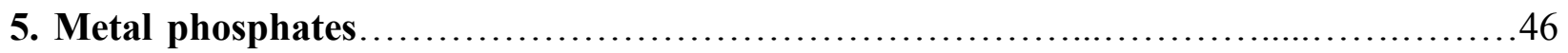

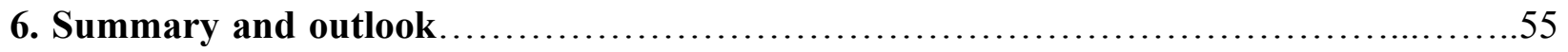

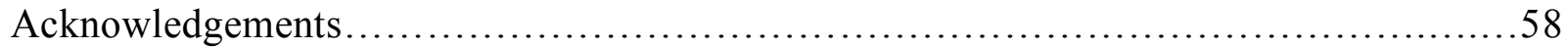

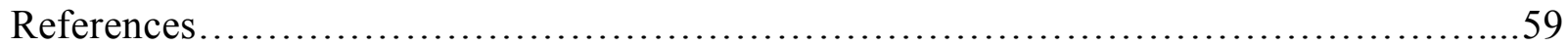


ABSTRACT: Second-order nonlinear optical (NLO) crystals functioning in the ultraviolet (UV) and deep-ultraviolet (deep-UV) regions are critically important as frequency conversion materials for all-solid-state UV laser devices. In this review, we focus on recent studies of inorganic UV and deep-UV NLO crystals with wide UV transparency and SHG efficiency. Following an introduction describing crystal-design strategies for UV and deep-UV NLO materials, the manuscript is organized according to the type of inorganic anions (borates, carbonates, nitrates and phosphates). Special attention is given to the crystal structures, second-order NLO properties, and structure-property correlations. The concluding remarks highlight future prospects in the field, with emphasis on the superiority of the different types of UV and deep-UV NLO crystals and the importance of large-size crystal growth for practical application in electro-optic devices.

Keywords: Borates, Carbonates, Nitrates, Phosphates, Crystal structure, SHG property 


\section{Introduction}

Coherent light generated by solid-state lasers is used in a wide variety of fields ranging from medical therapies to materials processing as well as information communication [1-3]. However, the wavelengths required for these applications cannot always be generated directly from a laser source, and so second-harmonic generation (SHG) from nonlinear optical (NLO) materials is an essential alternative means to afford the necessary wavelengths [4,5]. With this requirement in mind, the SHG-activity of a large number of inorganics, organics, organometallics, inorganicorganic hybrids, polymers and inorganic glasses have been investigated to date [6-10]. These second-order NLO-active materials are usually classified into four categories according to their working wavelength ranges in the spectrum: deep-ultraviolet (deep-UV, $\lambda<200 \mathrm{~nm}$ ), ultraviolet (UV, $\lambda<400 \mathrm{~nm}$ ), visible-near infrared (Vis-NIR), mid- and far-infrared (MFIR) materials. Amongst the materials under active current study, UV and deep-UV NLO crystals are attracting considerable attention for applications in, for example, semiconductor photolithography, laser micromachining, and scientific instrumentation [11-20,30]. The discovery and commercialization of second-order NLO inorganic crystals, such as $\beta$ - $\mathrm{BaB}_{2} \mathrm{O}_{4}\left(\beta\right.$-BBO) $[11,12], \mathrm{LiB}_{3} \mathrm{O}_{5}(\mathrm{LBO})$ $[13,14], \mathrm{CsLiB}_{6} \mathrm{O}_{10}(\mathrm{CLBO})[15,16], \mathrm{CsB}_{3} \mathrm{O}_{5}(\mathrm{CBO})[17,18], \mathrm{KBe}_{2} \mathrm{BO}_{3} \mathrm{~F}_{2}$ (KBBF) $[19,20]$ has progressed recently, but disadvantages have limited their practical use in optoelectronic devices. There remain great challenges to the development of new crystals that can directly generate UV or deep-UV coherent light by SHG, and the study of NLO crystals with high-performance SHG responses is therefore an important and high-profile topic in solid-state chemistry and laser technology $[21,22]$.

From the perspective of crystal structure, promising second-order NLO crystals should crystallize in noncentrosymmetric (NCS) space groups. Several strategies towards the creation of 
novel NCS crystals that contain NCS chromophores have been developed [23], such as the use of anions in $\pi$-delocalized systems, transition-metal cations with $\mathrm{d}^{0}$ electron configurations susceptible to second-order Jahn-Teller (SOJT) distortions, stereochemically-active lone-pair (SCALP) cations, and $\mathrm{d}^{10}$ transition-metal cations with polar displacements [24-28].

NLO-active crystals that can be used in the UV and deep-UV regions require a large transparency window (i.e. a wide bandgap), large SHG coefficients, moderate birefringence, chemical stability and facile growth of large single crystals $[29,30]$. The planar $\left[\mathrm{BO}_{3}\right]^{3-}$ and isoelectronic anions such as $\left[\mathrm{NO}_{3}\right]^{-}$and $\left[\mathrm{CO}_{3}\right]^{2-}$, which possess moderate birefringence and large microscopic second-order hyperpolarizabilities $\beta$, are believed to be the most favorable anionic units for UV and deep-UV candidates [31,32]. Phosphates have attracted attention as potential UV and deep-UV NLO candidates in recent years due to their wide UV transparency and the ease with which one can grow bulk crystals [33]. As far as the metal cations are concerned, alkali and alkaline-earth cations with no $\mathrm{d}-\mathrm{d}$ or $\mathrm{f}-\mathrm{f}$ electronic transitions and rare-earth cations with fullyoccupied $d\left(3 d^{10}\right)$ or half-occupied $f\left(4 f^{7}\right)$ electronic shells are commonly used in the pursuit of UV and deep-UV NLO crystals [34]. The introduction of halogens has been shown to influence crystal structure and cause a blue shift in the UV absorption spectra [35].

BBO and LBO were discovered in the 1980s [11-14]. These two crystals exhibit excellent NLO performance in both the visible and the UV regions. Nevertheless, the relatively narrow energy bandgap $\left(E_{\mathrm{g}}=6.5 \mathrm{eV}, \lambda=190 \mathrm{~nm}\right)$ in $\mathrm{BBO}$ and the small birefringence value $(\Delta n=$ $0.04 @ 400 \mathrm{~nm})$ in LBO restrict their applications in the deep-UV region. $\mathrm{KBe}_{2} \mathrm{BO}_{3} \mathrm{~F}_{2}(\mathrm{KBBF})$ $[19,20,36]$ and thereafter $\mathrm{RbBe}_{2} \mathrm{BO}_{3} \mathrm{~F}_{2}$ (RBBF) [36,37] and $\mathrm{CsBe}_{2} \mathrm{BO}_{3} \mathrm{~F}_{2}$ (CBBF) [36,38] were developed through molecular engineering design. The KBBF family possesses almost the same absorption edge $(150 \mathrm{~nm})$, moderately large SHG coefficients, and large birefringence. The 
shortest SHG phase-matching wavelength in $\mathrm{KBBF}$ is $161 \mathrm{~nm}$, while in RBBF and CBBF it redshifts to $170 \mathrm{~nm}$ and $201 \mathrm{~nm}$, respectively. However, the KBBF family of crystals exhibits a serious layering tendency during single-crystal growth due to their weak interlayer bonding, while the need for highly toxic beryllium oxide powders in the synthesis and crystal growth remains a major obstacle to their broader technological application. Further study directed to next-generation NLO crystals with good UV (and especially deep-UV) NLO performance is urgently needed.

This review highlights recent progress in the construction of second-order NLO inorganic crystals that are active in the UV and deep-UV regions, with a particular focus on their crystal structures, SHG properties, and structure-property relationships. Well-known NLO-active crystals such as $\beta-\mathrm{BaB}_{2} \mathrm{O}_{4}(\mathrm{BBO})[11,12], \mathrm{LiB}_{3} \mathrm{O}_{5}(\mathrm{LBO})[13,14], \mathrm{CsLiB}_{6} \mathrm{O}_{10}$ (CLBO) $[15,16], \mathrm{CsB}_{3} \mathrm{O}_{5}$ (CBO) [17,18], $\mathrm{Sr}_{2} \mathrm{Be}_{2} \mathrm{~B}_{2} \mathrm{O}_{7}(\mathrm{SBBO})$ [39], and $\mathrm{KBe}_{2} \mathrm{BO}_{3} \mathrm{~F}_{2}$ (KBBF) [34] have been extensively studied and commercialized, so they are not the focus of this review [40]. For the convenience of discussion, NLO crystals functioning in the UV and deep-UV regions are classified into four categories according to the anions: (1) metal borates, (2) metal carbonates, (3) metal nitrates, and (4) metal phosphates. We conclude the review by identifying the current critical challenges that impede the progress of the different types of UV and deep-UV NLO-active crystals into practical applications.

\section{Metal borates}

Combinations of $\left[\mathrm{BO}_{3}\right]$ planar triangles and $\left[\mathrm{BO}_{4}\right]$ tetrahedra give rise to a diverse array of borate structures. These compounds possess several interesting features. The large difference in electronegativity of the boron and oxygen atoms favors transmission of short-wavelength light, while the conjugated $\pi$-orbitals and highly anisotropic electron distribution in the $\left[\mathrm{BO}_{3}\right]$ groups is 
beneficial for the generation of large microscopic second-order susceptibilities and birefringence $[41,42]$. It has also been noted that elimination of dangling bonds at the oxygens in the $\mathrm{B}-\mathrm{O}$ groups can effectively increase the energy bandgap and blue-shift the absorption edge of borate crystals [43]. SHG-active metal borates can be classified into four categories based on their chemical composition: (1) metal borates without additional anions; (2) metal borates containing halides; (3) metal hydrated borates; (4) metal borates with mixed anions.

\subsection{Metal borates without additional anions}

Metal borates that do not possess additional anions are listed in Table $1 . \mathrm{NaBeB}_{3} \mathrm{O}_{6}(\mathbf{1})$ (space group $\left.P n a 2_{1}\right), \beta-\mathrm{KBe}_{2} \mathrm{~B}_{3} \mathrm{O}_{7}(2)\left(P m n 2_{1}\right), \gamma-\mathrm{KBe}_{2} \mathrm{~B}_{3} \mathrm{O}_{7}(3)\left(P 2_{1}\right)$, and $\mathrm{RbBe}_{2} \mathrm{~B}_{3} \mathrm{O}_{7}(4)\left(P m n 2_{1}\right)$ were obtained from high-temperature solution syntheses using alkaline borates as the flux [44]. The solid-state structure of $\mathbf{1}$ contains nearly coplanar fused six-membered rings $\left[\mathrm{Be}_{2} \mathrm{~B}_{3} \mathrm{O}_{11}\right]$ connected by $\left[\mathrm{BeO}_{4}\right]$ units. $\mathbf{2}$ and $\mathbf{4}$ are isostructural and, similar to $\mathbf{3}$, contain $\left[\mathrm{Be}_{2} \mathrm{~B}_{3} \mathrm{O}_{11}\right]_{\infty}$ layers that are linked by $\mathrm{B}-\mathrm{O}$ groups (Figure 1). The strong connections in these compounds provided by the covalent bonds between the layers may reduce the tendency for growth by layering that has hindered the applications of KBBF crystals. The absorption edges are below $200 \mathrm{~nm}$ for all four compounds. The phase-matchable SHG responses of 1-4 are about 1.6, 0.75, 0.68 and $0.79 \times \mathrm{KDP}$, respectively; the small SHG responses likely stem from the significant distances between the adjacent $\left[\mathrm{Be}_{2} \mathrm{~B}_{3} \mathrm{O}_{11}\right]_{\infty}$ layers in $\mathbf{2 - 4}$ which reduce the density of $\left[\mathrm{BO}_{3}\right]$ groups.

\section{Table 1}

NLO data for metal borates without additional anions

\begin{tabular}{llllll}
\hline Compounds & $\begin{array}{l}\text { Space } \\
\text { group }\end{array}$ & Structural features & Absorption edge & $\begin{array}{l}\text { SHG intensity } \\
(@ 1064 \mathrm{~nm})\end{array}$ & Ref. \\
\hline $\mathrm{NaBeB}_{3} \mathrm{O}_{6}$ & $P n a 2_{1}$ & {$\left[\mathrm{Be}_{2} \mathrm{~B}_{3} \mathrm{O}_{11}\right]$ layer } & $<200 \mathrm{~nm}(>6.2 \mathrm{eV})$ & $1.6 \times \mathrm{KDP}$ & {$[44]$} \\
$\beta-\mathrm{KBe}_{2} \mathrm{~B}_{3} \mathrm{O}_{7}$ & $P m n 2_{1}$ & {$\left[\mathrm{Be}_{2} \mathrm{BO}_{5}\right]$ layer } & $<200 \mathrm{~nm}(>6.2 \mathrm{eV})$ & $0.75 \times \mathrm{KDP}$ & {$[44]$} \\
$\gamma-\mathrm{KBe}_{2} \mathrm{~B}_{3} \mathrm{O}_{7}$ & $P 2_{1}$ & {$\left[\mathrm{Be}_{2} \mathrm{BO}_{5}\right]$ layer } & $<200 \mathrm{~nm}(>6.2 \mathrm{eV})$ & $0.68 \times \mathrm{KDP}$ & {$[44]$} \\
$\mathrm{RbBe}_{2} \mathrm{~B}_{3} \mathrm{O}_{7}$ & $P m n 2_{1}$ & {$\left[\mathrm{Be}_{2} \mathrm{BO}_{5}\right]$ layer } & $<200 \mathrm{~nm}(>6.2 \mathrm{eV})$ & $0.79 \times \mathrm{KDP}$ & {$[44]$}
\end{tabular}




\begin{tabular}{llllll}
$\mathrm{Na}_{2} \mathrm{CsBe}_{6} \mathrm{~B}_{5} \mathrm{O}_{15}$ & $C 2$ & {$\left[\mathrm{Be}_{2} \mathrm{BO}_{5}\right]$ layer } & $<200 \mathrm{~nm}(>6.2 \mathrm{eV})$ & $1.17 \times \mathrm{KDP}$ & {$[45]$} \\
$\mathrm{Na}_{2} \mathrm{Be}_{4} \mathrm{~B}_{4} \mathrm{O}_{11}$ & $P 1$ & {$\left[\mathrm{Be}_{2} \mathrm{BO}_{5}\right]$ layer } & $171 \mathrm{~nm}(7.25 \mathrm{eV})$ & $1.3 \times \mathrm{KDP}$ & {$[46]$} \\
$\mathrm{LiNa}_{5} \mathrm{Be}_{12} \mathrm{~B}_{12} \mathrm{O}_{33}$ & $P c$ & {$\left[\mathrm{Be}_{2} \mathrm{BO}_{5}\right]$ layer } & $169 \mathrm{~nm}(7.34 \mathrm{eV})$ & $1.4 \times \mathrm{KDP}$ & {$[46]$} \\
$\mathrm{YBe}_{2} \mathrm{~B}_{5} \mathrm{O}_{11}$ & $P n a 2_{1}$ & {$\left[\mathrm{Be}_{2} \mathrm{~B}_{5} \mathrm{O}_{11}\right]$ layer } & $<200 \mathrm{~nm}(>6.2 \mathrm{eV})$ & $1.0 \times \mathrm{KDP}$ & {$[47]$} \\
$\mathrm{GdBe}_{2} \mathrm{~B}_{5} \mathrm{O}_{11}$ & $P n a 2_{1}$ & {$\left[\mathrm{Be}_{2} \mathrm{~B}_{5} \mathrm{O}_{11}\right]$ layer } & $<200 \mathrm{~nm}(>6.2 \mathrm{eV})$ & $1.0 \times \mathrm{KDP}$ & {$[47]$} \\
$\mathrm{LaBeB}_{3} \mathrm{O}_{7}$ & $P n m 2_{1}$ & {$\left[\mathrm{BO}_{4}\right]$} & $220 \mathrm{~nm}(5.63 \mathrm{eV})$ & $1.0 \sim 2.0 \times \mathrm{KDP}$ & {$[48]$} \\
$\mathrm{Cs}_{3} \mathrm{Zn}_{6} \mathrm{~B}_{9} \mathrm{O}_{21}$ & $C m c 2_{1}$ & {$\left[\mathrm{Zn}_{2} \mathrm{BO}_{3} \mathrm{O}_{2}\right]$ layer } & $<200 \mathrm{~nm}(>6.2 \mathrm{eV})$ & $3.30 \times \mathrm{KDP}$ & {$[49,50]$} \\
$\mathrm{Li}_{4} \mathrm{Sr}_{\left(\mathrm{BO}_{3}\right)_{2}}$ & $C c$ & {$\left[\mathrm{SrBO}_{3}\right]$ layer } & $186 \mathrm{~nm}(6.67 \mathrm{eV})$ & $2.0 \times \mathrm{KDP}$ & {$[51]$} \\
$\beta-\mathrm{Rb}_{2} \mathrm{Al}_{2} \mathrm{~B}_{2} \mathrm{O}_{7}$ & $P 321$ & {$\left[\mathrm{Al}_{1}\left(\mathrm{BO}_{3}\right)_{3} \mathrm{O}\right]$ layer } & $<200 \mathrm{~nm}(>6.2 \mathrm{eV})$ & $2.0 \times \mathrm{KDP}$ & {$[52]$} \\
$\mathrm{Li}_{4} \mathrm{Cs}_{3} \mathrm{~B}_{7} \mathrm{O}_{14}$ & $P 3_{12} 1$ & {$\left[\mathrm{~B}_{7} \mathrm{O}_{14}\right]$} & $<190 \mathrm{~nm}(>6.53 \mathrm{eV})$ & $0.5 \times \mathrm{KDP}$ & {$[54,55]$} \\
$\mathrm{Li}_{4} \mathrm{Rb}_{3} \mathrm{~B}_{7} \mathrm{O}_{14}$ & $P 3{ }_{1} 21$ & {$\left[\mathrm{~B}_{7} \mathrm{O}_{14}\right]$} & $<190 \mathrm{~nm}(>6.53 \mathrm{eV})$ & $0.67 \times \mathrm{KDP}$ & {$[55]$} \\
$\mathrm{Li}_{6} \mathrm{Rb}_{5} \mathrm{~B}_{11} \mathrm{O}_{22}$ & $C 2$ & {$\left[\mathrm{~B}_{11} \mathrm{O}_{12}\right]$} & $<190 \mathrm{~nm}(>6.53 \mathrm{eV})$ & $0.67 \times \mathrm{KDP}$ & {$[55,56]$} \\
$\mathrm{Li}_{3} \mathrm{Cs}_{2} \mathrm{~B}_{5} \mathrm{O}_{10}$ & $C 222_{1}$ & {$\left[\mathrm{~B}_{5} \mathrm{O}_{10}\right]$} & $175 \mathrm{~nm}(7.09 \mathrm{eV})$ & $0.5 \times \mathrm{KDP}$ & {$[53,55]$} \\
$\mathrm{Li}_{5} \mathrm{Cs}_{2} \mathrm{~B}_{7} \mathrm{O}_{14}$ & $A m a 2$ & {$\left[\mathrm{~B}_{5} \mathrm{O}_{12}\right]$} & $<200 \mathrm{~nm}(>6.2 \mathrm{eV})$ & $0.2 \times \mathrm{KDP}$ & {$[57]$} \\
$\mathrm{LiNaB}_{4} \mathrm{O}_{7}$ & $F d d 2$ & {$\left[\mathrm{~B}_{4} \mathrm{O}_{9}\right]$} & $180 \mathrm{~nm}(6.89 \mathrm{eV})$ & $0.15 \times \mathrm{KDP}$ & {$[58]$} \\
$\mathrm{NaCa}_{4} \mathrm{~B}_{3} \mathrm{O}_{9}$ & $A m a 2$ & {$\left[\mathrm{BO}_{3}\right]$} & $288 \mathrm{~nm}(4.3 \mathrm{eV})$ & $0.5 \times \mathrm{KDP}$ & {$[59]$} \\
$\mathrm{LiPbB}_{9} \mathrm{O}_{15}$ & $R 3 c$ & {$\left[\mathrm{~B}_{3} \mathrm{O}_{7}\right]$} & $261 \mathrm{~nm}(4.75 \mathrm{eV})$ & $1.0 \times \mathrm{KDP}$ & {$[60]$} \\
\hline
\end{tabular}

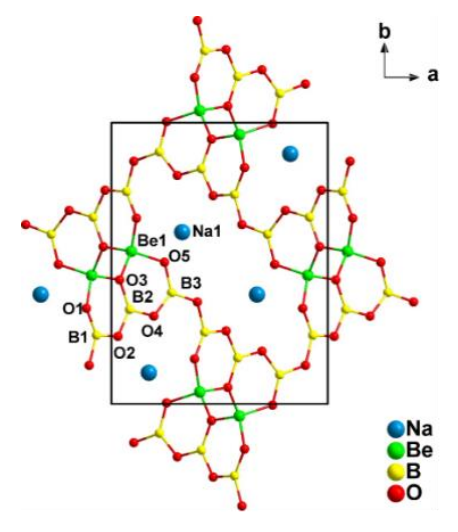

(a)

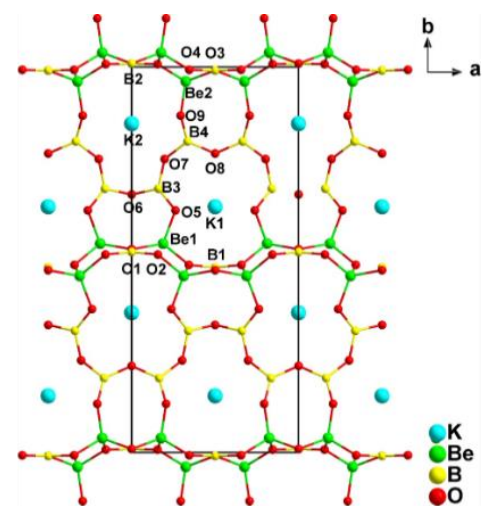

(b)

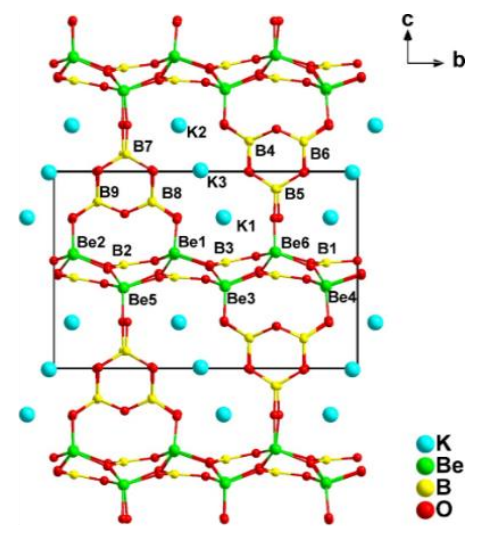

(c)

Figure 1. Crystal structures of (a) $\mathrm{NaBeB}_{3} \mathrm{O}_{6}$ (1), (b) $\beta-\mathrm{KBe}_{2} \mathrm{~B}_{3} \mathrm{O}_{7}$ (2), and (c) $\gamma-\mathrm{KBe}_{2} \mathrm{~B}_{3} \mathrm{O}_{7}$ (3) [44]. (c) 2010 American Chemical Society.

To reduce the interlayer spacing in beryllium borates and thereby increase the density of SHG-active $\left[\mathrm{BO}_{3}\right]$ groups, $\mathrm{Na}_{2} \mathrm{CsBe}_{6} \mathrm{~B}_{5} \mathrm{O}_{15}$ (5) (C2) [45], $\mathrm{Na}_{2} \mathrm{Be}_{4} \mathrm{~B}_{4} \mathrm{O}_{11}$ (6) (P1) [46], and $\mathrm{LiNa}_{5} \mathrm{Be}_{12} \mathrm{~B}_{12} \mathrm{O}_{33}(7)(P c)$ [46] were grown by spontaneous crystallization from a molten flux 
based on $\mathrm{Na}_{2} \mathrm{O}-\mathrm{Cs}_{2} \mathrm{O}-\mathrm{B}_{2} \mathrm{O}_{3}, \mathrm{Na}_{2} \mathrm{O}-\mathrm{BeO}-\mathrm{B}_{2} \mathrm{O}_{3}$ and $\mathrm{Li}_{2} \mathrm{O}-\mathrm{Na}_{2} \mathrm{O}-\mathrm{BeO}-\mathrm{B}_{2} \mathrm{O}_{3}$, respectively. Their structures also feature $\left[\mathrm{Be}_{2} \mathrm{~B}_{3} \mathrm{O}_{11}\right]_{\infty}$ layers that are bridged by $\left[\mathrm{BO}_{3}\right]$ groups in 5 and $\left[\mathrm{B}_{2} \mathrm{O}_{5}\right]$ groups in 6 and 7 (Figure 2). This strategy resulted in enhanced SHG responses, 1.17, 1.3 and $1.4 \times$ KDP for 5-7, respectively. All three materials possess an absorption edge below $200 \mathrm{~nm}$ (171 nm for 6 and $169 \mathrm{~nm}$ for 7 ).

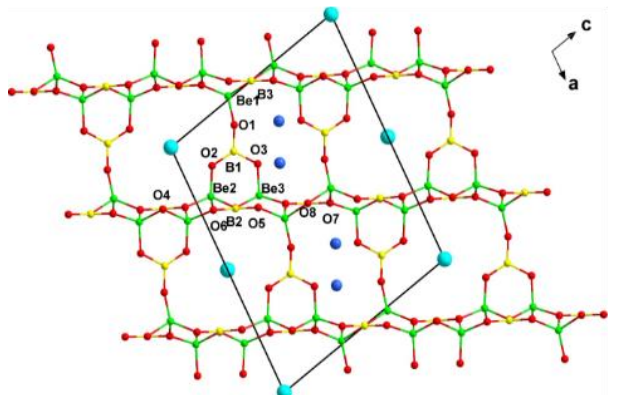

(a)

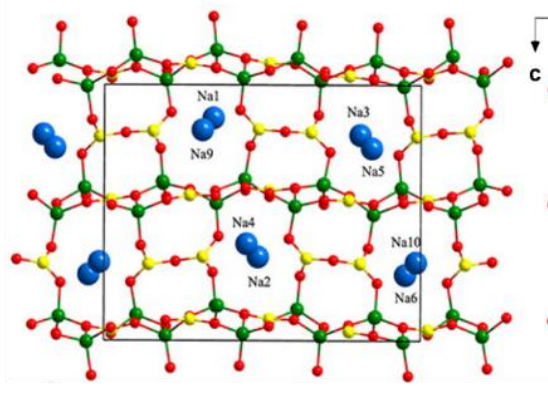

(b)

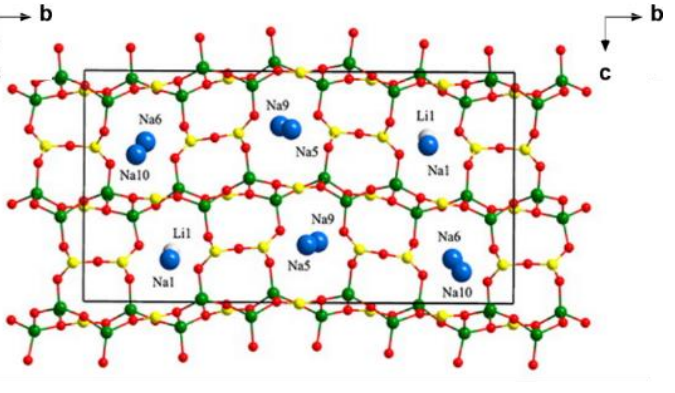

(c)

Figure 2. Crystal structures of (a) $\mathrm{Na}_{2} \mathrm{CsBe}_{6} \mathrm{~B}_{5} \mathrm{O}_{15}$ (5), (b) $\mathrm{Na}_{2} \mathrm{Be}_{4} \mathrm{~B}_{4} \mathrm{O}_{11}$ (6), and (c) $\mathrm{LiNa}_{5} \mathrm{Be}_{12} \mathrm{~B}_{12} \mathrm{O}_{33}$ (7) $[45,46]$. (c) 2010, 2013 American Chemical Society.

Rare-earth beryllium borates with layered structures have been explored as potential deepUV NLO materials. These were grown through spontaneous nucleation from the melt of a $\operatorname{Re}_{2} \mathrm{O}_{3}$ BeO- $\mathrm{B}_{2} \mathrm{O}_{3}-\mathrm{Li}_{2} \mathrm{O}$ mixture [47]. The $\mathrm{MBe}_{2} \mathrm{~B}_{5} \mathrm{O}_{11}\left(\mathrm{M}=\mathrm{Y}(\mathbf{8}), \mathrm{Gd}(\mathbf{9}) ;\left(P n a 2_{1}\right)\right)$ compounds are isostructural, containing $\left[\mathrm{Be}_{2} \mathrm{~B}_{5} \mathrm{O}_{11}\right]_{\infty}$ layers connected via rare-earth cations, and possess shortwavelength absorption edges below $200 \mathrm{~nm}$. SHG measurements reveal that 8 and 9 are phasematchable with SHG responses similar to KDP. Crystalline $\mathrm{LaBeB}_{3} \mathrm{O}_{7}(\mathbf{1 0})\left(P n a 2_{1}\right)$ was grown from a high-temperature solution by using $\mathrm{Li}_{2} \mathrm{O}-\mathrm{B}_{2} \mathrm{O}_{3}$ as the flux [48]; the structure has some boron sites substituted by beryllium atoms, resulting in corner-sharing $\left[\mathrm{BO}_{4}\right]$ and $\left[\mathrm{BeO}_{4}\right]$ tetrahedral groups. These $\left[\mathrm{XO}_{4}\right](\mathrm{X}=\mathrm{B}$ and $\mathrm{Be})$ tetrahedra align along the $c$-axis, affording relatively large SHG effects $(1 \sim 2 \times \mathrm{KDP})$; SHG measurements also reveal that 10 is phase-matchable at $1064 \mathrm{~nm}$.

$\mathrm{Cs}_{3} \mathrm{Zn}_{6} \mathrm{~B}_{9} \mathrm{O}_{21}(\mathbf{1 1})\left(C m c 2_{1}\right)[49,50]$ was prepared by a spontaneous nucleation approach from a $\mathrm{Cs}_{2} \mathrm{O}-\mathrm{ZnF}_{2}-\mathrm{B}_{2} \mathrm{O}_{3}$ flux, the structure consisting of $\left[\mathrm{Zn}_{2} \mathrm{BO}_{3} \mathrm{O}_{2}\right]_{\infty}$ layers connected by $\left[\mathrm{B}_{3} \mathrm{O}_{6}\right]$ 
groups (Figure 3). Remarkably, it exhibits a large SHG response of 3.3 times that of KDP despite a reduced $\left[\mathrm{BO}_{3}\right]$ number density. Computational studies by the density functional theory (DFT) method suggested that the enhanced SHG response originates from cooperation between the coparallel $\left[\mathrm{BO}_{3}\right]$ triangles and distorted $\left[\mathrm{ZnO}{ }_{4}\right]$ tetrahedra in the $\left[\mathrm{Zn}_{2} \mathrm{BO}_{3} \mathrm{O}_{2}\right]_{\infty}$ layers (Figure 4). The absorption edge of $\mathbf{1 1}$ is below $200 \mathrm{~nm}$.

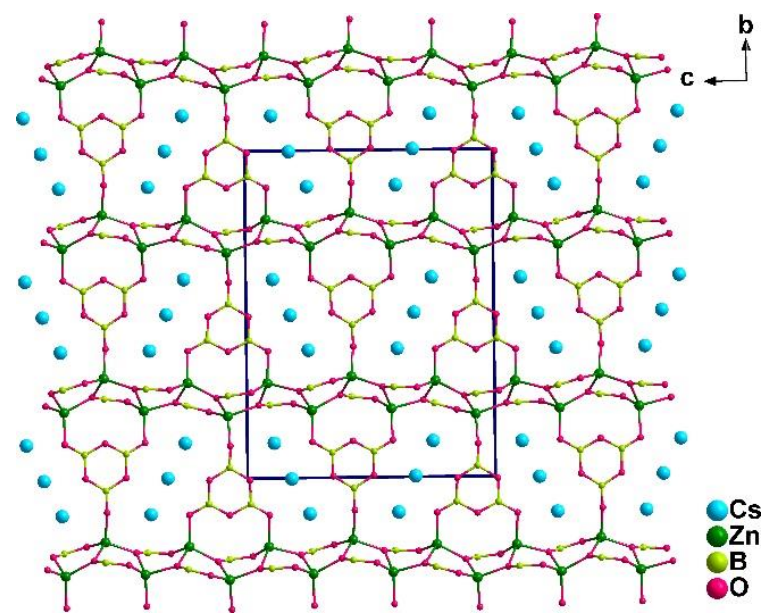

Figure 3. Crystal structure of $\mathrm{Cs}_{3} \mathrm{Zn}_{6} \mathrm{~B}_{9} \mathrm{O}_{21}$ (11) [49]. (c) 2014 American Chemical Society.

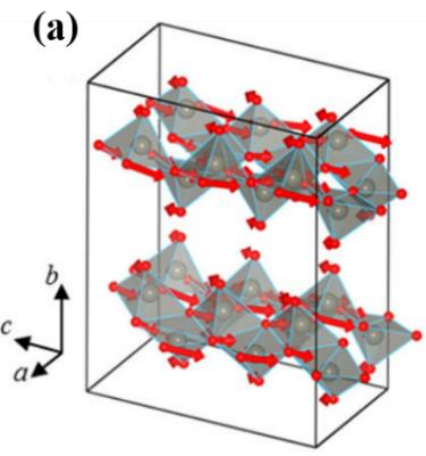

(b)

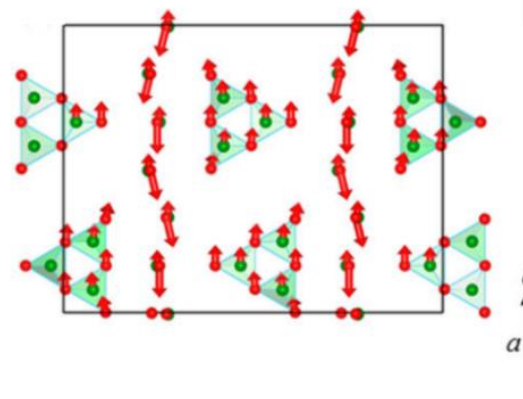

(c)

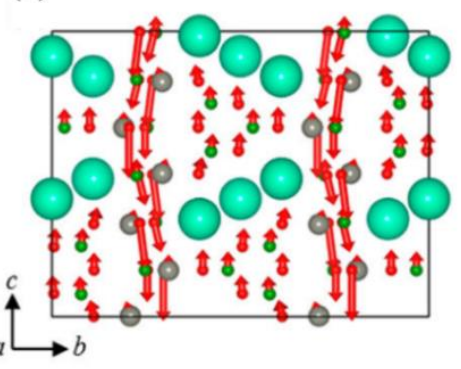

Figure 4. Atomic distortion patterns of $\mathbf{1 1}$ obtained from symmetry-mode analysis: Oxygen atom displacements belonging to (a) the $\mathrm{ZnO}_{4}$ tetrahedra, (b) the $\mathrm{BO}_{3}$ network, and (c) the complete distortion projected along the a axis [49]. () 2014 American Chemical Society.

Crystalline $\mathrm{Li}_{4} \mathrm{Sr}\left(\mathrm{BO}_{3}\right)_{2}$ (12) (Cc) [51] was grown by the top-seeded solution growth (TSSG) method from a $\mathrm{Li}_{2} \mathrm{O}-\mathrm{SrO}-\mathrm{B}_{2} \mathrm{O}_{3}$ flux. Its $3 \mathrm{D}$ network structure consists of $\left[\mathrm{SrBO}_{3}\right]$ layers separated by $\left[\mathrm{BO}_{3}\right]$ groups (Figure 5), and it possesses an absorption edge of $186 \mathrm{~nm} .12$ is phase-matchable 
not only in the visible region but also in the UV region, with a powder SHG response of $2.0 \times$ KDP at $1064 \mathrm{~nm}$. The calculated birefringence is $\Delta n=0.056 @ 532 \mathrm{~nm}$.

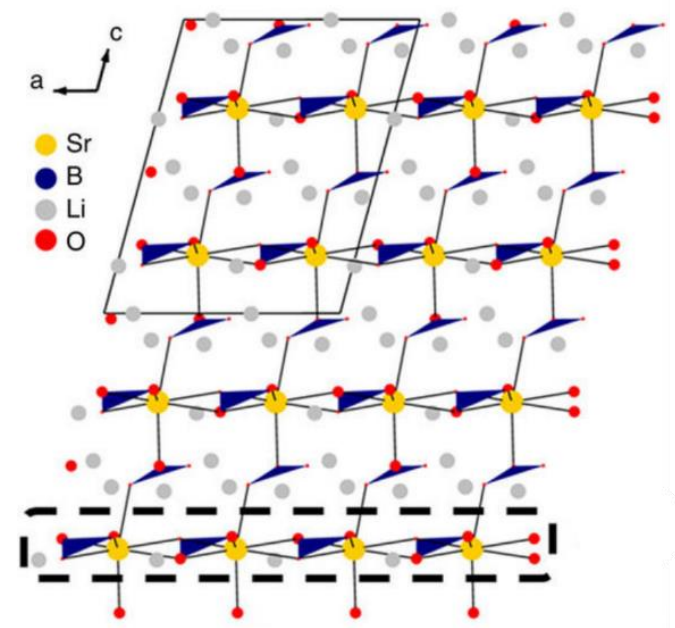

Figure 5. Crystal structure of $\mathrm{Li}_{4} \mathrm{Sr}\left(\mathrm{BO}_{3}\right)_{2}$ (12) [51]. (c) 2014 Macmillan Publishers.

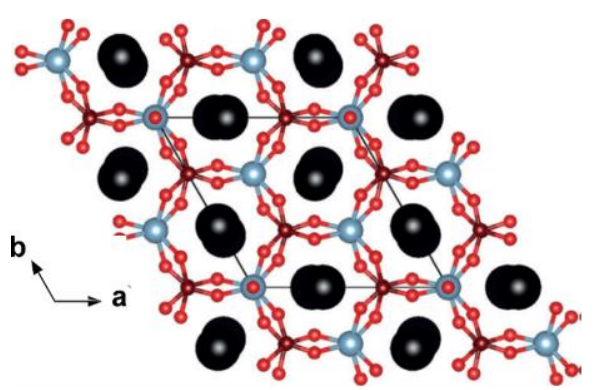

(a)

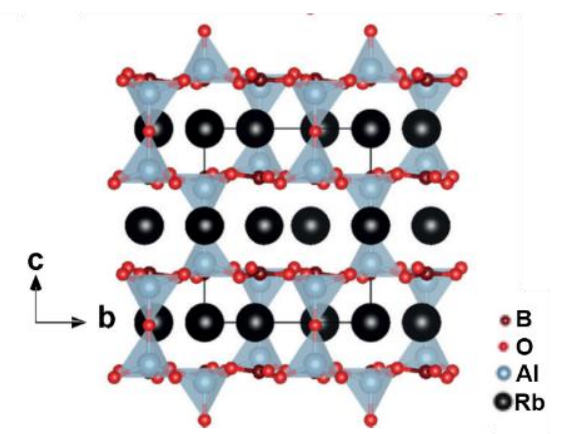

(b)

Figure 6. Crystal structure of $\beta-\mathrm{Rb}_{2} \mathrm{Al}_{2} \mathrm{~B}_{2} \mathrm{O}_{7}$ (13); (a) the $\mathrm{Rb}$ cations reside in the tunnels created by the $\mathrm{Al}\left(\mathrm{BO}_{3}\right)_{3} \mathrm{O}$ tetrahedra, and (b) the tetrahedra are connected through $\mathrm{O}$ atoms [52]. (c) 2017 WILEY-VCH.

Polycrystalline $\beta-\mathrm{Rb}_{2} \mathrm{Al}_{2} \mathrm{~B}_{2} \mathrm{O}_{7}$ (13) was synthesized by a solid-state reaction and a single crystal grown from a high-temperature solution using a $\mathrm{H}_{3} \mathrm{BO}_{3}-\mathrm{RbF}-\mathrm{PbO}$ flux. It crystallizes in the trigonal space group $P 321$ [52], the structure consisting of $\left[\mathrm{BO}_{3}\right.$ ] groups connected to $\left[\mathrm{AlO}_{4}\right]$ tetrahedra, and with the charge balance maintained by $\mathrm{Rb}^{+}$cations (Figure 6). The material shows an absorption edge below $200 \mathrm{~nm}$ while SHG measurement indicates a type I phase-matchable behavior with an efficiency of $2.0 \times \mathrm{KDP}$. 


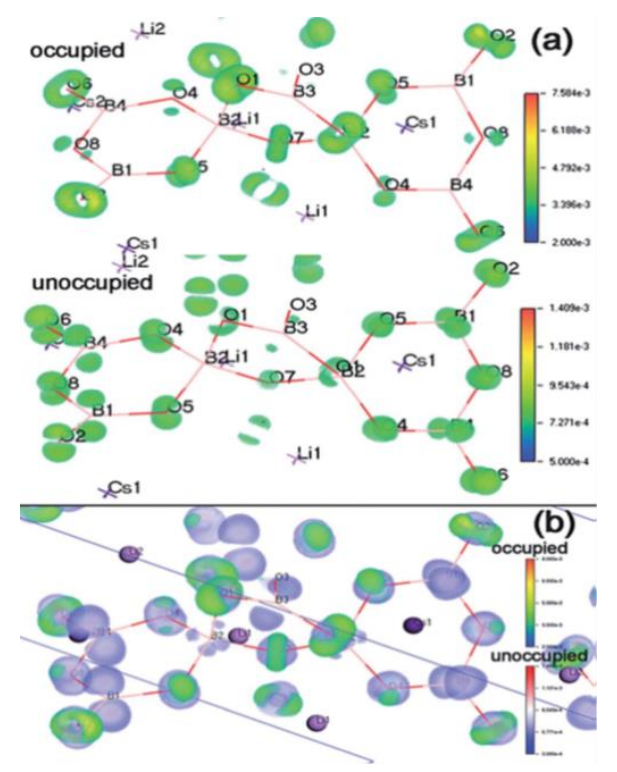

Figure 7. (a) SHG-density of occupied states and unoccupied states. (b) Charge transfer excitation from the nonbonding $2 \mathrm{p}$ occupied states of the $\mathrm{O}$ atoms (green) to the $\mathrm{p}$ unoccupied states of $\mathrm{B}$ and $\mathrm{O}$ (violet) is the key mechanism for the NLO properties of $\mathbf{1 5}$ [55]. (C) 2014 Royal Society of Chemistry.

In addition to the aforementioned metal borates with layered structures, other mixed-metal borates have been developed as NLO materials. $\mathrm{Li}_{3} \mathrm{Cs}_{2} \mathrm{~B}_{5} \mathrm{O}_{10}$ (14) $\left(C 222_{1}\right), \mathrm{Li}_{4} \mathrm{Cs}_{3} \mathrm{~B}_{7} \mathrm{O}_{14}$ (15) ( $\left.P 3_{1} 21\right), \mathrm{Li}_{4} \mathrm{Rb}_{3} \mathrm{~B}_{7} \mathrm{O}_{14}(\mathbf{1 6})\left(P 3_{1} 21\right)$ and $\mathrm{Li}_{6} \mathrm{Rb}_{5} \mathrm{~B}_{11} \mathrm{O}_{22}(\mathbf{1 7})(C 2)$ were synthesized via solid-state reactions and feature topologically similar $\mathrm{B}-\mathrm{O}$ groups $\left(\left[\mathrm{B}_{5} \mathrm{O}_{10}\right],\left[\mathrm{B}_{7} \mathrm{O}_{14}\right],\left[\mathrm{B}_{11} \mathrm{O}_{12}\right]\right)$ interconnected by $\mathrm{LiO}_{\mathrm{n}}(\mathrm{n}=4,5)$ and $\mathrm{Rb} / \mathrm{CsO}_{\mathrm{n}}(\mathrm{n}=8,9,10)[53-56]$. SHG efficiencies are $0.5,0.5,0.67$, and 0.67 $\times$ KDP for 14-17, respectively, with all four crystals exhibiting a short UV absorption edge (below $190 \mathrm{~nm}$ ). Computational studies by the SHG-density method demonstrated that "charge-transfer excitation" from the non-bonding $2 \mathrm{p}$ occupied states of the $\mathrm{O}$ atoms to the $\pi^{*}$ and $2 \mathrm{p}$ unoccupied states of the $\mathrm{BO}_{3}$ substructure is the key determinant of NLO properties of 14-17 this crystal family (Figure 7) [55]. Similar examples containing $\mathrm{Li}_{5} \mathrm{Cs}_{2} \mathrm{~B}_{7} \mathrm{O}_{14}(\mathbf{1 8})$ (Ama2) [57], $\mathrm{LiNaB}_{4} \mathrm{O}_{7}(\mathbf{1 9})(F d d 2)$ [58], $\mathrm{NaCa}_{4} \mathrm{~B}_{3} \mathrm{O}_{9}(20)$ (Ama2) [59], and $\mathrm{LiPbB}_{9} \mathrm{O}_{15}(21)$ (R3c) [60] were grown from hightemperature solutions; all four were found to be SHG-active with responses of $0.2,0.15,0.5$, and $1.0 \times \mathrm{KDP}$, respectively, with absorption edges in the UV region. 
Metal borates without additional anions are usually prepared by solid-state reaction techniques and, thus far, several KBBF-family crystals with improved layer growth have been reported. However, these crystals do not possess the optical advantages of KBBF, while their toxic Be content decreases their applicability. A few crystals exploiting nontoxic elements have been reported (e.g. $\mathrm{Cs}_{3} \mathrm{Zn}_{6} \mathrm{~B}_{9} \mathrm{O}_{21}, \mathrm{Li}_{4} \mathrm{Sr}_{(}\left(\mathrm{BO}_{3}\right)_{2}, \beta-\mathrm{Rb}_{2} \mathrm{Al}_{2} \mathrm{~B}_{2} \mathrm{O}_{7}$ ), but large optical-quality crystals are needed.

\subsection{Metal borates containing halides}

Metal borates containing halides are listed in Table 2, the majority showing structural differences to other borates. Introduction of halides into borates can significantly influence their NLO properties for the following reasons: (1) the probability of NCS compounds is increased; (2) the electronic structures of the compounds are varied; (3) large distortions and polarizabilities of the local structural units can be induced; (4) the absorption edge can be blue shifted (eg. $\mathrm{F}^{-}$anions) $[33,36,61]$.

\section{Table 2}

NLO data for metal borates containing halides

\begin{tabular}{llllll}
\hline Compounds & $\begin{array}{l}\text { Space } \\
\text { group }\end{array}$ & Structural features & Absorption edge & $\begin{array}{l}\text { SHG intensity Ref. } \\
(@ 1064 \mathrm{~nm})\end{array}$ \\
\hline $\mathrm{BaBe}_{2} \mathrm{BO}_{3} \mathrm{~F}_{3}$ & $P 6_{3}$ & {$\left[\mathrm{Be}_{2} \mathrm{BO}_{3} \mathrm{~F}_{2}\right]$ layer } & $<185 \mathrm{~nm}(>6.70 \mathrm{eV})$ & $0.1 \times \mathrm{KDP}$ & {$[62]$} \\
$\mathrm{NaCaBe}_{2} \mathrm{~B}_{2} \mathrm{O}_{6} \mathrm{~F}$ & $C c$ & {$\left[\mathrm{Be}_{3} \mathrm{~B}_{3} \mathrm{O}_{6} \mathrm{~F}_{3}\right]$ layer } & $190 \mathrm{~nm}(6.53 \mathrm{eV})$ & $0.33 \times \mathrm{KDP}$ & {$[63]$} \\
$\mathrm{K}_{3} \mathrm{Ba}_{3} \mathrm{Li}_{2} \mathrm{Al}_{4} \mathrm{~B}_{6} \mathrm{O}_{20} \mathrm{~F}$ & $P \overline{6} 2 c$ & {$\left[\mathrm{Li}_{2} \mathrm{Al}_{4} \mathrm{~B}_{6} \mathrm{O}_{20} \mathrm{~F}\right]$ layer } & $190 \mathrm{~nm}(6.53 \mathrm{eV})$ & $1.5 \times \mathrm{KDP}$ & {$[64]$} \\
$\mathrm{NaSr}_{3} \mathrm{Be}_{3} \mathrm{~B}_{3} \mathrm{O}_{9} \mathrm{~F}_{4}$ & $R 3 m$ & {$\left[\mathrm{Be}_{3} \mathrm{~B}_{3} \mathrm{O}_{12} \mathrm{~F}\right]$} & $170 \mathrm{~nm}(7.29 \mathrm{eV})$ & $3.0 \times \mathrm{KDP}$ & {$[65]$} \\
$\mathrm{Sr}_{3} \mathrm{Be}_{1.9} \mathrm{~B}_{5.1} \mathrm{O}_{12.1} \mathrm{~F}_{0.9}$ & $R 3 m$ & {$\left[\left(\mathrm{Be} / \mathrm{B}_{3} \mathrm{~B}_{3} \mathrm{O}_{10}\right]\right.$} & $<200 \mathrm{~nm}(>6.2 \mathrm{eV})$ & $2.2 \times \mathrm{KDP}$ & {$[66]$} \\
$\mathrm{Rb}_{3} \mathrm{Al}_{3} \mathrm{~B}_{3} \mathrm{O}_{10} \mathrm{~F}$ & $P 3{ }_{1} c$ & {$\left[\mathrm{Al}_{3}\left(\mathrm{BO}_{3}\right)_{3} \mathrm{OF}\right]$ layer } & $<200 \mathrm{~nm}(>6.2 \mathrm{eV})$ & $1.2 \times \mathrm{KDP}$ & {$[67]$} \\
$\mathrm{KZn}_{2} \mathrm{BO}_{3} \mathrm{Cl}_{2}$ & $R 32$ & Isolated $\left[\mathrm{BO}_{3}\right]$ & $193 \mathrm{~nm}(6.42 \mathrm{eV})^{a}$ & $3.01 \times \mathrm{KDP}$ & {$[68,69]$} \\
$\mathrm{RbZn}_{2} \mathrm{BO}_{3} \mathrm{Cl}_{2}$ & $R 32$ & Isolated $\left[\mathrm{BO}_{3}\right]$ & $198 \mathrm{~nm}(6.25 \mathrm{eV})^{a}$ & $2.85 \times \mathrm{KDP}$ & {$[68,69]$} \\
$\mathrm{KZn}_{2} \mathrm{BO}_{3} \mathrm{Br}_{2}$ & $R 32$ & Isolated $\left[\mathrm{BO}_{3}\right]$ & $206 \mathrm{~nm}(6.01 \mathrm{eV})^{a}$ & $2.68 \times \mathrm{KDP}$ & {$[68,69]$} \\
$\mathrm{RbZn}_{2} \mathrm{BO}_{3} \mathrm{Br}_{2}$ & $R 32$ & Isolated $\left[\mathrm{BO}_{3}\right]$ & $214 \mathrm{~nm}(5.79 \mathrm{eV})^{a}$ & $2.53 \times \mathrm{KDP}$ & {$[68,69]$} \\
$\mathrm{BaMgBO}_{3} \mathrm{~F}$ & $C c$ & Isolated $\left[\mathrm{BO}_{3}\right]$ & $190 \mathrm{~nm}(6.53 \mathrm{eV})$ & $0.1 \times \mathrm{KDP}$ & {$[72,73]$}
\end{tabular}




\begin{tabular}{|c|c|c|c|c|c|}
\hline$\beta-\mathrm{BaCaBO}_{3} \mathrm{~F}$ & $P \overline{6} 2 m$ & Isolated $\left[\mathrm{BO}_{3}\right]$ & $210 \mathrm{~nm}(5.90 \mathrm{eV})$ & $0.7 \times \mathrm{KDP}$ & {$[70,71]$} \\
\hline $\mathrm{BaZnBO}_{3} \mathrm{~F}$ & $P \overline{6}$ & Isolated $\left[\mathrm{BO}_{3}\right]$ & $223 \mathrm{~nm}(5.56 \mathrm{eV})$ & $2.8 \times \mathrm{KDP}$ & {$[72,74]$} \\
\hline $\mathrm{Ba}_{3} \mathrm{Sr}_{4}\left(\mathrm{BO}_{3}\right)_{3} \mathrm{~F}_{5}$ & $P 6_{3} m c$ & Isolated $\left[\mathrm{BO}_{3}\right]$ & $210 \mathrm{~nm}(5.90 \mathrm{eV})$ & $0.5 \times \mathrm{KDP}$ & {$[75]$} \\
\hline $\mathrm{Li}_{3} \mathrm{Ca}_{9}\left(\mathrm{BO}_{3}\right)_{7} \cdot 2[\mathrm{LiF}]$ & $P 1$ & Isolated $\left[\mathrm{BO}_{3}\right]$ & $230 \mathrm{~nm}(5.39 \mathrm{eV})^{a}$ & $1.0 \times \mathrm{KDP}$ & [76] \\
\hline $\mathrm{Cd}_{5}\left(\mathrm{BO}_{3}\right)_{3} \mathrm{~F}$ & $\mathrm{Cm}$ & Isolated $\left[\mathrm{BO}_{3}\right]$ & $282 \mathrm{~nm}(4.4 \mathrm{eV})$ & $3.8 \times \mathrm{KDP}$ & {$[77]$} \\
\hline $\mathrm{Pb}_{2} \mathrm{BO}_{3} \mathrm{Cl}$ & $P 321$ & Isolated $\left[\mathrm{BO}_{3}\right]$ & $300 \mathrm{~nm}(3.99 \mathrm{eV})$ & $9.0 \times \mathrm{KDP}$ & {$[78]$} \\
\hline $\mathrm{NaBa}_{4}\left(\mathrm{AlB}_{4} \mathrm{O}_{9}\right)_{2} \mathrm{Cl}_{3}$ & $\mathrm{P} 4_{2} \mathrm{~nm}$ & {$\left[\mathrm{~B}_{4} \mathrm{O}_{9}\right]$} & $315 \mathrm{~nm}(3.93 \mathrm{eV})$ & $0.9 \times \mathrm{KDP}$ & {$[79,82]$} \\
\hline $\mathrm{NaBa}_{4}\left(\mathrm{GaB}_{4} \mathrm{O}_{9}\right)_{2} \mathrm{Cl}_{3}$ & $\mathrm{P} 4_{2} \mathrm{~nm}$ & {$\left[\mathrm{~B}_{4} \mathrm{O}_{9}\right]$} & $330 \mathrm{~nm}(3.76 \mathrm{eV})$ & $1.5 \times \mathrm{KDP}$ & {$[81,83]$} \\
\hline $\mathrm{NaBa}_{4}\left(\mathrm{AlB}_{4} \mathrm{O}_{9}\right)_{2} \mathrm{Br}_{3}$ & $P 4_{2} \mathrm{~nm}$ & {$\left[\mathrm{~B}_{4} \mathrm{O}_{9}\right]$} & $314 \mathrm{~nm}(3.95 \mathrm{eV})$ & $0.8 \times \mathrm{KDP}$ & {$[80]$} \\
\hline $\mathrm{NaBa}_{4}\left(\mathrm{GaB}_{4} \mathrm{O}_{9}\right)_{2} \mathrm{Br}_{3}$ & $P 4_{2} n m$ & {$\left[\mathrm{~B}_{4} \mathrm{O}_{9}\right]$} & $334 \mathrm{~nm}(3.71 \mathrm{eV})$ & $1.1 \times \mathrm{KDP}$ & [83] \\
\hline $\mathrm{K}_{3} \mathrm{~B}_{6} \mathrm{O}_{10} \mathrm{Cl}$ & $R 3 m$ & {$\left[\mathrm{~B}_{6} \mathrm{O}_{10}\right]$} & $180 \mathrm{~nm}(6.89 \mathrm{eV})$ & $4.0 \times \mathrm{KDP}$ & {$[90,91]$} \\
\hline $\mathrm{K}_{3} \mathrm{~B}_{6} \mathrm{O}_{10} \mathrm{Br}$ & $R 3 m$ & {$\left[\mathrm{~B}_{6} \mathrm{O}_{10}\right]$} & $184 \mathrm{~nm}(6.74 \mathrm{eV})$ & $3.0 \times \mathrm{KDP}$ & [84-89] \\
\hline $\mathrm{Na}_{3} \mathrm{~B}_{6} \mathrm{O}_{10} \mathrm{Cl}$ & $P 2_{1} 2_{1} 2_{1}$ & {$\left[\mathrm{~B}_{6} \mathrm{O}_{10}\right]$} & $<190 \mathrm{~nm}(>6.53 \mathrm{eV})$ & Very small & {$[92]$} \\
\hline $\mathrm{RbNa}_{2} \mathrm{~B}_{6} \mathrm{O}_{10} \mathrm{Cl}$ & $P 2_{1} 2_{1} 2_{1}$ & {$\left[\mathrm{~B}_{6} \mathrm{O}_{10}\right]$} & $<190 \mathrm{~nm}(>6.53 \mathrm{eV})$ & Very small & {$[92]$} \\
\hline $\mathrm{K}_{2.33} \mathrm{Na}_{0.67} \mathrm{~B}_{6} \mathrm{O}_{10} \mathrm{Br}$ & $R 3 m$ & {$\left[\mathrm{~B}_{6} \mathrm{O}_{10}\right]$} & $<190 \mathrm{~nm}(>6.53 \mathrm{eV})$ & $2.8 \times \mathrm{KDP}$ & [93] \\
\hline $\mathrm{K}_{2.87} \mathrm{Na}_{0.13} \mathrm{~B}_{6} \mathrm{O}_{10} \mathrm{Br}$ & $R 3 m$ & {$\left[\mathrm{~B}_{6} \mathrm{O}_{10}\right]$} & $<190 \mathrm{~nm}(>6.53 \mathrm{eV})$ & $2.8 \times \mathrm{KDP}$ & [93] \\
\hline $\mathrm{Sr}_{3} \mathrm{~B}_{6} \mathrm{O}_{11} \mathrm{~F}_{2}$ & $P 2_{1}$ & {$\left[\mathrm{~B}_{6} \mathrm{O}_{14}\right]$} & $<190 \mathrm{~nm}(>6.53 \mathrm{eV})$ & $2.5 \times \mathrm{KDP}$ & {$[94,97]$} \\
\hline $\mathrm{Ba}_{3} \mathrm{~B}_{6} \mathrm{O}_{11} \mathrm{~F}_{2}$ & $P 2_{1}$ & {$\left[\mathrm{~B}_{6} \mathrm{O}_{14}\right]$} & $<200 \mathrm{~nm}(>6.2 \mathrm{eV})$ & $3 \times \mathrm{KDP}$ & {$[94,95]$} \\
\hline $\mathrm{Pb}_{3} \mathrm{~B}_{6} \mathrm{O}_{11} \mathrm{~F}_{2}$ & $P 2_{1}$ & {$\left[\mathrm{~B}_{6} \mathrm{O}_{14}\right]$} & $240 \mathrm{~nm}(5.17 \mathrm{eV})$ & $4 \times \mathrm{KDP}$ & {$[96]$} \\
\hline $\mathrm{Ba}_{4} \mathrm{~B}_{11} \mathrm{O}_{20} \mathrm{~F}$ & $C m c 2_{1}$ & {$\left[\mathrm{~B}_{11} \mathrm{O}_{24}\right]$} & $175 \mathrm{~nm}(7.09 \mathrm{eV})$ & $10 \times \mathrm{KDP}$ & {$[98]$} \\
\hline $\mathrm{Li}_{2} \mathrm{~B}_{6} \mathrm{O}_{9} \mathrm{~F}_{2}$ & $C c$ & {$\left[\mathrm{~B}_{6} \mathrm{O}_{9} \mathrm{~F}_{2}\right]$} & $<190 \mathrm{~nm}(>6.53 \mathrm{eV})$ & $0.9 \times \mathrm{KDP}$ & {$[99,100]$} \\
\hline $\mathrm{BaClBF}_{4}$ & $\operatorname{Pmn} 2_{1}$ & {$\left[\mathrm{BF}_{4}\right]$} & $180 \mathrm{~nm}(6.89 \mathrm{eV})$ & $0.2 \times \mathrm{KDP}$ & {$[101]$} \\
\hline
\end{tabular}

${ }^{a}$ Energy bandgap.

After the well-known deep-UV NLO crystal KBBF was reported, $\mathrm{BaBe}_{2} \mathrm{BO}_{3} \mathrm{~F}_{3}(\mathbf{2 2})\left(P 6_{3}\right)$ [62] was discovered through a molecular engineering design approach; its structure contains the unique $\left[\mathrm{Be}_{2} \mathrm{BO}_{3} \mathrm{~F}_{2}\right]_{\infty}$ layers seen in $\mathrm{KBBF}$, but they are separated by $\mathrm{Ba}^{2+}$ dications in $\mathrm{BBBF}$ (Figure 8). 22 shows a weak SHG response with an absorption edge below $185 \mathrm{~nm}$. First-principles calculations suggest that the large birefringence $(\Delta n=0.081 @ 200 \mathrm{~nm})$ and moderate refractiveindex dispersion are the keys to ensure phase-matchable SHG activity into the deep-UV region $(\sim 196 \mathrm{~nm})$. Single crystals of 22 can be grown by spontaneous crystallization from a flux of $\mathrm{BaCO}_{3}-\mathrm{BaF}_{2}-\mathrm{BeO}-\mathrm{NaF}-\mathrm{NaBF}_{4}-\mathrm{H}_{3} \mathrm{BO}_{3}$, but they suffer from a layering tendency and the highly 
toxic beryllium oxide powder used in the synthesis and crystal growth remains a major obstacle to broader technological applications.
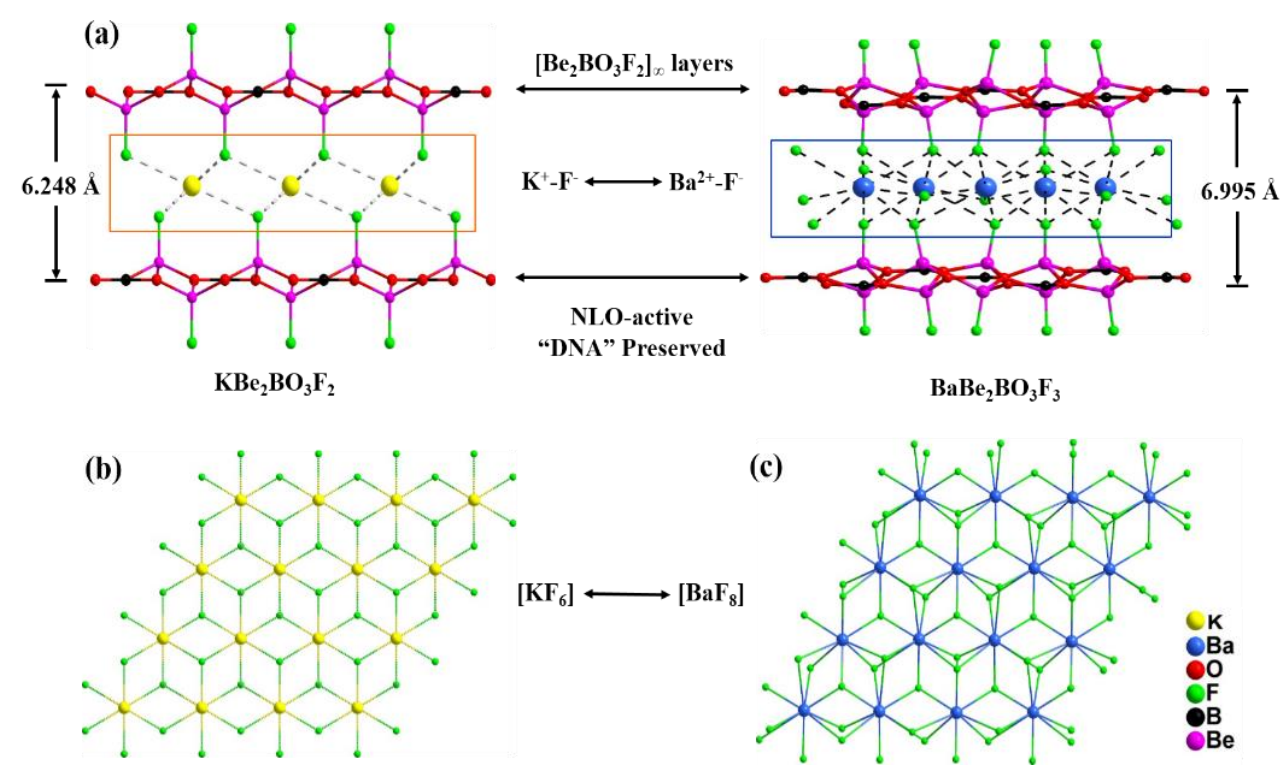

Figure 8. (a) Structural evolution from $\mathrm{KBBF}$ to $\mathrm{BaBe}_{2} \mathrm{BO}_{3} \mathrm{~F}_{3}$ (22). (b) $[\mathrm{KF}]$ layer of $\mathrm{KBBF}$. (c) [BaF] layer of 22 [62]. () 2016 American Chemical Society.

The crystal structures of $\mathrm{Sr}_{2} \mathrm{Be}_{2} \mathrm{~B}_{2} \mathrm{O}_{7}(\mathrm{SBBO})$-type compounds possess $\left[\mathrm{M}_{2} \mathrm{~B}_{2} \mathrm{O}_{6} \mathrm{X}\right]_{\infty}$ double layers, with the A-site cations located between the double layers. For example, $\mathrm{NaCaBe}_{2} \mathrm{~B}_{2} \mathrm{O}_{6} \mathrm{~F}$ (23) $(C c)$ [63] and $\mathrm{K}_{3} \mathrm{Ba}_{3} \mathrm{Li}_{2} \mathrm{Al}_{4} \mathrm{~B}_{6} \mathrm{O}_{20} \mathrm{~F}(\mathbf{2 4})(P \overline{6} 2 c)$ [64] were obtained with dimensions of $30 \times$ $30 \times 4$ and $10 \times 5 \times 3 \mathrm{~mm}^{3}$ from $\mathrm{B}_{2} \mathrm{O}_{3}-\mathrm{NaF}-\mathrm{CaF}_{2}$ and $\mathrm{Li}_{2} \mathrm{O}-\mathrm{BaF}_{2}-\mathrm{B}_{2} \mathrm{O}_{3}$ flux systems, respectively $23(C c)$ exhibits a $2 \mathrm{D}\left[\mathrm{Be}_{2} \mathrm{~B}_{2} \mathrm{O}_{6} \mathrm{~F}\right]_{\infty}$ double-layer structure with bridging oxygens in the double layer of SBBO replaced by fluorine atoms (Figure 9); its absorption edge is $190 \mathrm{~nm}$, and it displays a weak SHG response (about one third that of KDP). Single crystals of $\mathbf{2 4}$ were grown by the TSSG method from the flux $\mathrm{Li}_{2} \mathrm{O}-\mathrm{BaF}_{2}-\mathrm{B}_{2} \mathrm{O}_{3}$. The structure is composed of $\left[\mathrm{Li}_{2} \mathrm{Al}_{4} \mathrm{~B}_{6} \mathrm{O}_{20} \mathrm{~F}\right]_{\infty}$ double-layers with $\mathrm{Ba}^{2+}$ dications residing in the interlayer space and $\mathrm{K}^{+}$cations occupying the cavities of the $\left[\mathrm{Li}_{2} \mathrm{Al}_{4} \mathrm{~B}_{6} \mathrm{O}_{20} \mathrm{~F}\right]_{\infty}$ double-layers (Figure 10). Its absorption edge is $190 \mathrm{~nm}$ and it displays a moderate $\mathrm{SHG}$ response $(1.5 \times \mathrm{KDP})$. Interestingly, the bond distances $(\mathrm{Li}-\mathrm{F}, \mathrm{Al}-\mathrm{O})$ in 
24 result in the $\left[\mathrm{Li}_{2} \mathrm{Al}_{4} \mathrm{~B}_{6} \mathrm{O}_{20} \mathrm{~F}\right]_{\infty}$ double-layers possessing suitable space to accommodate the large $\mathrm{K}^{+}$cations, which overcomes the structure-instability problem inherent in the structure of SBBO. Phonon dispersion calculations by the linear response method support the conclusion that the structural instability problem of SBBO is eliminated in $\mathbf{2 4}$ (Figure 11) [64].

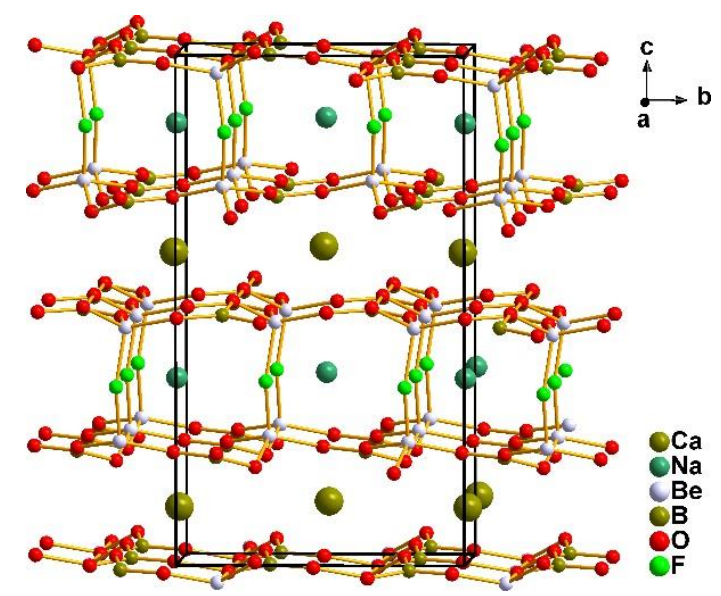

Figure 9. Crystal structure of $\mathrm{NaCaBe}_{2} \mathrm{~B}_{2} \mathrm{O}_{6} \mathrm{~F}$ (23) [63]. (c) 2011 American Chemical Society.

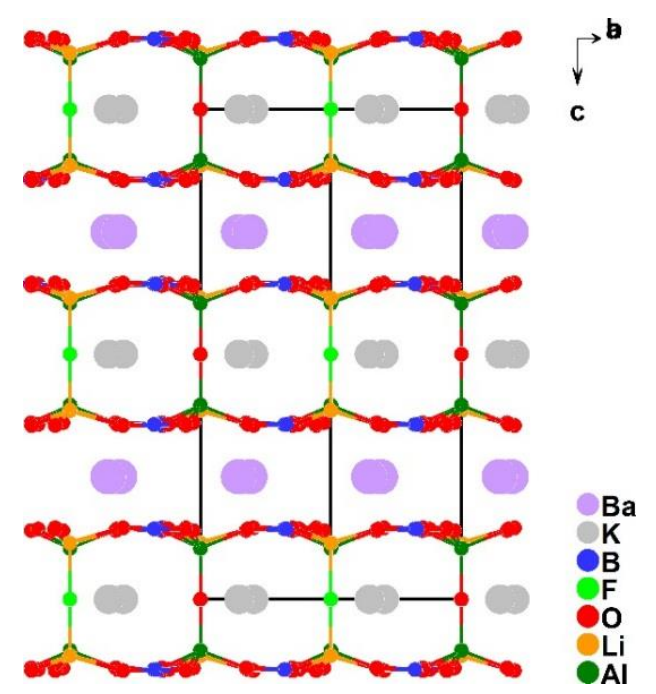

Figure 10. Crystal structure of $\mathrm{K}_{3} \mathrm{Ba}_{3} \mathrm{Li}_{2} \mathrm{Al}_{4} \mathrm{~B}_{6} \mathrm{O}_{20} \mathrm{~F}$ (24) [64]. (c) 2016 American Chemical Society. 


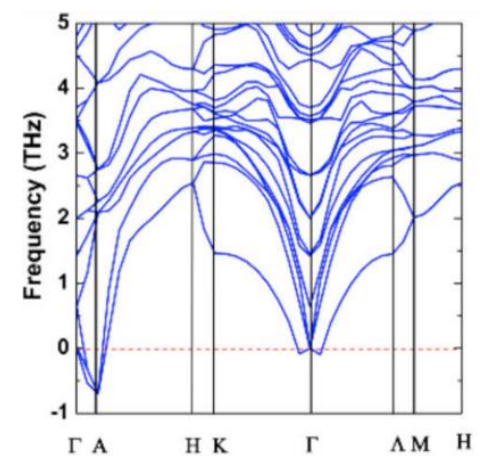

(a)

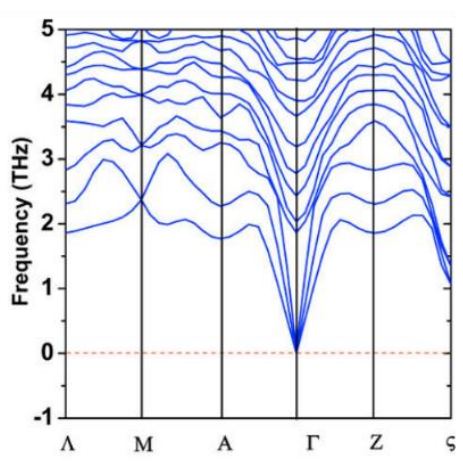

(b)

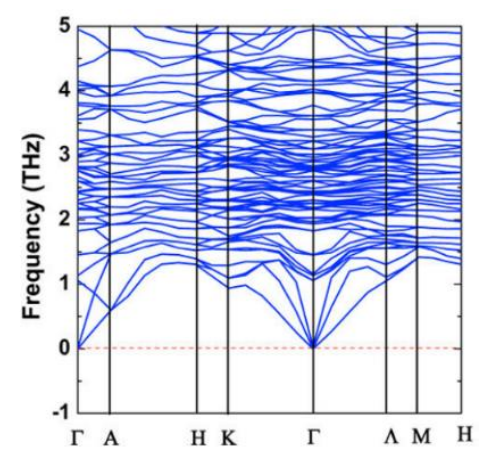

(c)

Figure 11. Phonon dispersion of (a) SBBO, (b) 23, and (c) 24 [64]. (c) 2016 American Chemical Society.

$\mathrm{NaSr}_{3} \mathrm{Be}_{3} \mathrm{~B}_{3} \mathrm{O}_{9} \mathrm{~F}_{4}(\mathbf{2 5})(R 3 m)$ features a $3 \mathrm{D}\left[\mathrm{Be}_{3} \mathrm{~B}_{3} \mathrm{O}_{12} \mathrm{~F}\right]_{\infty}$ anionic framework with $\mathrm{Sr}^{2+}, \mathrm{Na}^{+}$, and isolated $\mathrm{F}^{-}$ions in the cavities (Figure 12) [65]; it has a short-wavelength absorption edge of $170 \mathrm{~nm}$ and is phase-matchable with a strong SHG response $($ ca. $3.0 \times \mathrm{KDP})$. Large crystals $(20 \times$ $20 \times 10 \mathrm{~mm}^{3}$ ) were grown by spontaneous crystallization using $\mathrm{B}_{2} \mathrm{O}_{3}-\mathrm{NaF}$ as flux media. $\mathrm{Sr}_{3}\left[\left(\mathrm{Be}_{\mathrm{x}} \mathrm{B}_{1-\mathrm{x}}\right)_{3} \mathrm{~B}_{3} \mathrm{O}_{10}\right]\left[\mathrm{Be}\left(\mathrm{O}_{1-\mathrm{x}} \mathrm{F}_{\mathrm{x}}\right)_{3}\right](\mathrm{x}=0.30)(\mathbf{2 6})(R 3 m)(\mathrm{SBBOF})$ containing $\left[\left(\mathrm{Be}_{\mathrm{x}} \mathrm{B}_{1-\mathrm{x}}\right)_{3} \mathrm{~B}_{3} \mathrm{O}_{10}\right]$ anionic groups and $\left[\mathrm{Be}\left(\mathrm{O}_{1-\mathrm{x}} \mathrm{F}_{\mathrm{x}}\right)_{3}\right]$ planar groups was recently reported [66], single crystals being successfully grown from a high-temperature solution using $\mathrm{SrO}-\mathrm{B}_{2} \mathrm{O}_{3}-\mathrm{LiF}$ as a flux. The absorption edge of $\mathbf{2 6}$ is below $200 \mathrm{~nm}$ and SHG measurements indicate that it is phase-matchable in both the visible and the UV regions, with a SHG coefficient of $2.2 \times \mathrm{KDP}$.

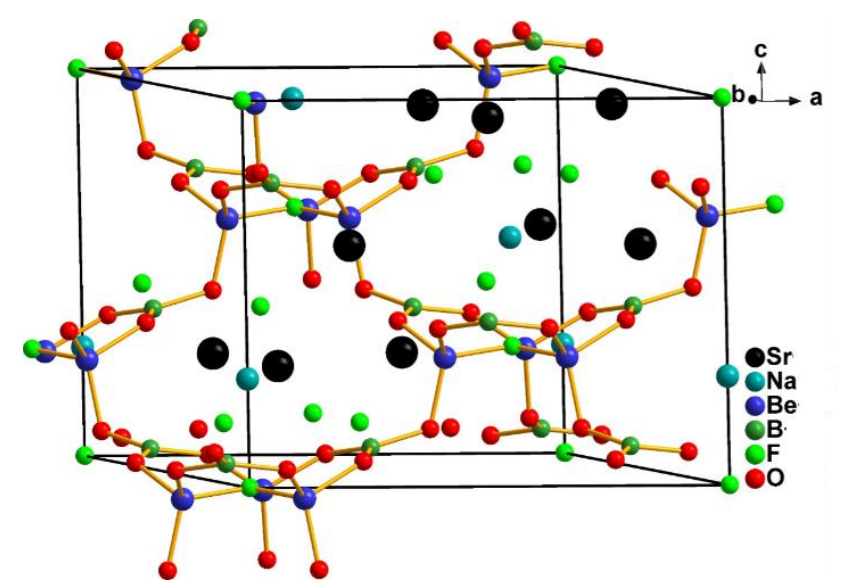

Figure 12. Crystal structure of $\mathrm{NaSr}_{3} \mathrm{Be}_{3} \mathrm{~B}_{3} \mathrm{O}_{9} \mathrm{~F}_{4}$ (25) [65]. (c) 2011 WILEY-VCH. 
Beryllium-free borate halides have also attracted recent attention. According to the diagonal relationships of the Periodic Table, aluminum is physically and chemically similar to beryllium. Polycrystalline samples of $\mathrm{Rb}_{3} \mathrm{Al}_{3} \mathrm{~B}_{3} \mathrm{O}_{10} \mathrm{~F}$ (27) $\left(P 3_{1} c\right)$ were synthesized by the HTSS technique, and a single crystal was then grown from a high-temperature solution using a $\mathrm{RbF}-\mathrm{B}_{2} \mathrm{O}_{3}$ flux [67]; its structure consists of $\left[\mathrm{Al}_{3}\left(\mathrm{BO}_{3}\right)_{3} \mathrm{OF}\right]_{\infty}$ layers bound via $\mathrm{Al}-\mathrm{O}$ and $\mathrm{Al}-\mathrm{F}$ bridged bonds (Figure 13). The compound is transparent to wavelengths below $200 \mathrm{~nm}$ and exhibits type I phasematchable behavior with a powder SHG efficiency of $1.2 \times$ KDP. Remarkably, 27 exhibits a strong interlayer bonding, about one order of magnitude larger than that of KBBF, and so no layering tendency was observed during the crystal growth.

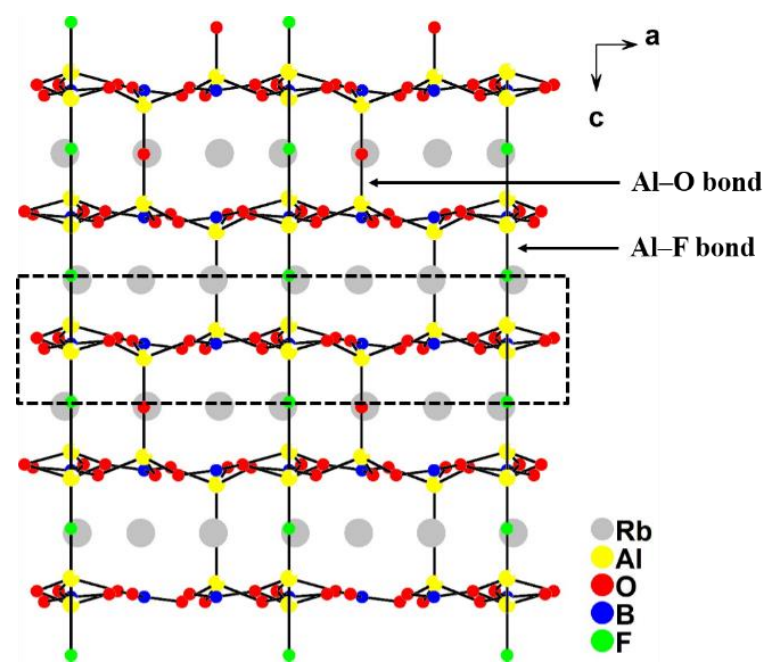

Figure 13. Crystal structure of $\mathrm{Rb}_{3} \mathrm{Al}_{3} \mathrm{~B}_{3} \mathrm{O}_{10} \mathrm{~F}$ (27) [67]. (C) 2015 American Chemical Society.

The isostructural crystals $\mathrm{KZn}_{2} \mathrm{BO}_{3} \mathrm{Cl}_{2}(\mathbf{2 8}), \mathrm{RbZn}_{2} \mathrm{BO}_{3} \mathrm{Cl}_{2}(\mathbf{2 9}), \mathrm{KZn}_{2} \mathrm{BO}_{3} \mathrm{Br}_{2}(\mathbf{3 0})$, and $\mathrm{RbZn}_{2} \mathrm{BO}_{3} \mathrm{Br}_{2}(\mathbf{3 1})$ all in $R 32$ space group were obtained using either high-temperature solution methods or solvothermal techniques. SHG measurements revealed very strong SHG responses (3.01, 2.85, 2.68, and $2.53 \times \mathrm{KDP}$ for $\mathbf{2 8 - 3 1}$, respectively); the compounds are phase-matchable in the visible and UV regions and possess absorption edges in the deep-UV region $[68,69]$. The structures of these compounds exhibit infinite planar $\left[\mathrm{Zn}_{2} \mathrm{BO}_{3} \mathrm{X}_{2}\right]_{\infty}$ layers that preserve the 
structural merits of KBBF (Figure 14). Theoretical calculations suggest that the enhanced SHG responses originate from a cooperative effect of the co-parallel $\left[\mathrm{BO}_{3}\right]$ triangles and distorted $\left[\mathrm{ZnO}_{3} \mathrm{Cl} / \mathrm{Br}\right]$ tetrahedra.

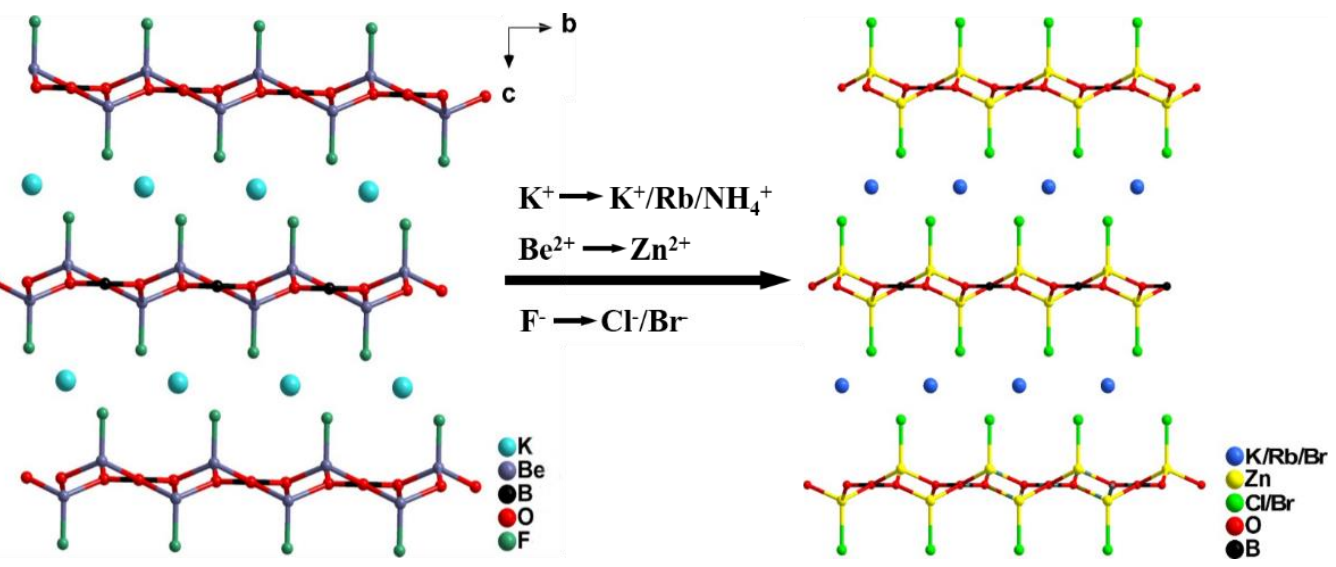

Figure 14. Structural evolution from $\mathrm{KBBF}$ to $\mathrm{AZn}_{2} \mathrm{BO}_{3} \mathrm{X}_{2}$ (28-31) [68]. (c) 2016 American Chemical Society.

$\mathrm{BaXBO}_{3} \mathrm{~F}(\mathrm{X}=\mathrm{Mg}(\mathbf{3 2})(C c), \mathrm{Ca}(\mathbf{3 3})(P \overline{6} 2 m), \mathrm{Zn}(\mathbf{3 4})(R 32))$ have been synthesized by HTSS methods [70-74]; their structures contain $\left[\mathrm{MgO}_{4} \mathrm{~F}_{2} \mathrm{BO}_{3}\right],\left[\mathrm{CaO}_{2} \mathrm{~F}_{2} \mathrm{BO}_{3}\right]$, and $\left[\mathrm{ZnO}_{3} \mathrm{~F}_{2} \mathrm{BO}_{3}\right]$ layers, respectively, with $\mathrm{Ba}^{2+}$ cations located between the layers. The $\left[\mathrm{BO}_{3}\right]$ groups in $\mathbf{3 4}$ are aligned with the same orientation, but in contrast, a non-directional alignment of the $\left[\mathrm{BO}_{3}\right]$ groups is observed in the structures of $\mathbf{3 2}$ and 33. This differing orientation of $\left[\mathrm{BO}_{3}\right]$ groups may be the reason that $\mathbf{3 4}$ possesses the largest SHG response $(3 \times \mathrm{KDP})$ of the three compounds. A further mixed-alkaline-earth-metal borate halide $\mathrm{Ba}_{3} \mathrm{Sr}_{4}\left(\mathrm{BO}_{3}\right)_{3} \mathrm{~F}_{5}(35)\left(P 6_{3} m c\right)$ has been obtained by the TSSG method [75]. Its SHG response is about $0.5 \times \mathrm{KDP}$, and its UV absorption edge is ca. 210 nm.

Single crystals of $\mathrm{Li}_{3} \mathrm{Ca}_{9}\left(\mathrm{BO}_{3}\right)_{7} \cdot 2[\mathrm{LiF}](36)(P 1)$ were grown from a high-temperature melt of $\mathrm{Li}_{2} \mathrm{CO}_{3}-\mathrm{LiF}-\mathrm{CaO}-\mathrm{H}_{3} \mathrm{BO}_{3}$ [76]. 36 is a $\mathrm{LiF}$ salt-inclusion borate with the $\mathrm{Li}-\mathrm{F}$ chains residing in the $\left[\mathrm{Li}_{3} \mathrm{Ca} 9\left(\mathrm{BO}_{3}\right)_{7}\right]$ 3D framework (Figure 15). Its structure is completely different to all aforementioned borate halides, the high-density and coplanar arrangement of the $\left[\mathrm{BO}_{3}\right]$ triangles 
affording 36 a moderate SHG response $(1.0 \times \mathrm{KDP})$ and a relatively large birefringence $(\Delta n=$ $0.07 @ 532 \mathrm{~nm}$ ). In addition, it has wide transparency with an absorption edge at $230 \mathrm{~nm}$. The structural study of $\mathrm{Cd}_{5}\left(\mathrm{BO}_{3}\right)_{3} \mathrm{~F}(\mathbf{3 7})(\mathrm{Cm})$, the crystals of which were grown through HTSS recently, reveals isolated $\left[\mathrm{BO}_{3}\right]$ planar triangles approximately parallel to the (001) plane [77]. The SHG efficiency of $\mathbf{3 7}$ is $3.8 \times \mathrm{KDP}$, but its UV absorption edge is ca. $280 \mathrm{~nm}$; the comparatively large SHG response originates from the polar arrangement of the $\mathrm{d}^{10} \mathrm{Cd}^{2+}$ cations and the $\pi$ conjugated triangular $\left[\mathrm{BO}_{3}\right]$ groups.

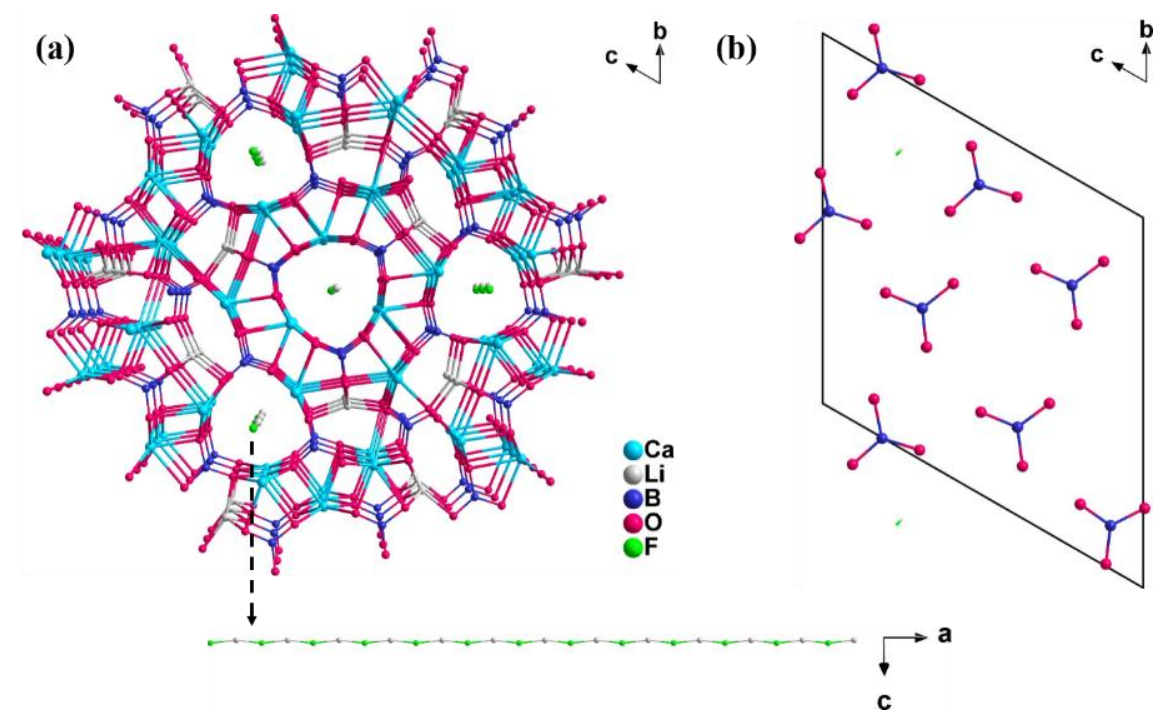

Figure 15. (a) $3 \mathrm{D}$ framework structure of $\mathbf{3 6}$ showing the $\mathrm{Li}-\mathrm{F}$ chains. (b) Coplanar arrangement of $\left[\mathrm{BO}_{3}\right]$ triangles in the unit cell [76]. (C) 2013, American Chemical Society.

The noncentrosymmetric crystal $\mathrm{Pb}_{2} \mathrm{BO}_{3} \mathrm{Cl}$ (38) (P321) was synthesized through a hightemperature solid-state reaction [78]. Its 3D framework structure is composed of cationic $\left[\mathrm{Pb}_{2} \mathrm{BO}_{3}\right]^{+}$layers made from $\mathrm{BO}_{3}$ triangular units and $\mathrm{PbO}_{3}$ trigonal pyramids with $\mathrm{Cl}^{-}$anions residing in the interlayer space. As a new member of the KBBF family, $\mathbf{3 8}$ can also be written as $[\mathrm{Cl}]^{-}\left[\mathrm{Pb}_{2} \mathrm{BO}_{3}\right]^{+}$, with a structure comparable to that of $[\mathrm{K}]^{+}\left[\mathrm{Be}_{2} \mathrm{BO}_{3} \mathrm{~F}_{2}\right]^{-}$(Figure 16). SHG measurements indicated that $\mathbf{3 8}$ is type I phase-matchable and exhibits a remarkably strong SHG response $(9.0 \times \mathrm{KDP})$, constituting the largest value ever reported for the KBBF family. The 
compound has no absorption from 300 to $2500 \mathrm{~nm}$; the material has a wide transparency region ranging from the near-UV to the mid-IR. Electron localization function (ELF) diagrams implied that the large SHG response originates from cooperation between the lone pairs on the $\mathrm{Pb}^{2+}$ cations and $\mathrm{Cl}^{-}$anions, and the $\mathrm{p}-\pi$ interactions between $\mathrm{Pb}^{2+}$ and $\left[\mathrm{BO}_{3}\right]^{3-}$ groups within the extended $\left[\mathrm{Pb}_{2}\left(\mathrm{BO}_{3}\right)\right]^{+}$layers (Figure 17).

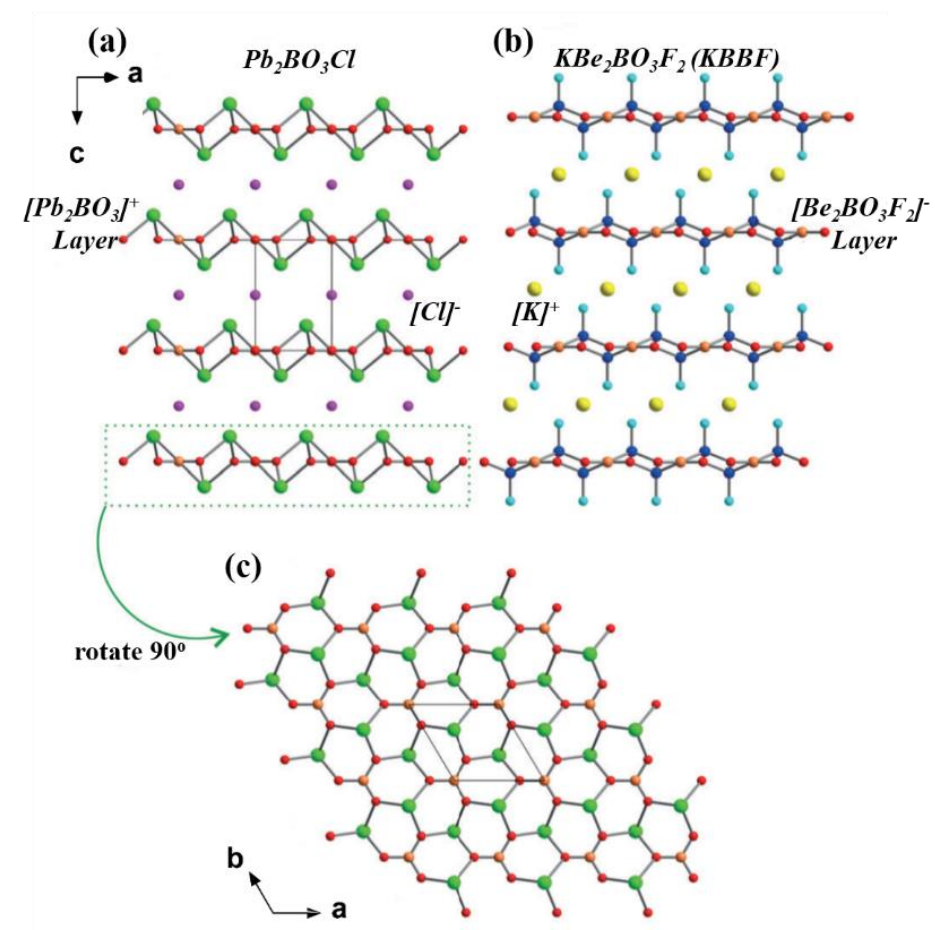

Figure 16. Ball-and-stick models of (a) 38 and (b) $\mathrm{KBe}_{2} \mathrm{BO}_{3} \mathrm{~F}_{2}(\mathrm{KBBF}$ ) in the $a c$ plane. $\mathrm{B}$ orange, Be blue, $\mathrm{Cl}$ purple, $\mathrm{F}$ cyan, $\mathrm{K}$ yellow, $\mathrm{O}$ red, $\mathrm{Pb}$ green. (c) Each $\mathrm{BO}_{3}$ planar triangle shares its corners with six $\mathrm{PbO}_{3}$ trigonal pyramids and forms a honeycomb-like cationic $\left[\mathrm{Pb}_{2} \mathrm{BO}_{3}\right]^{+}$layer in the $a b$ plane of 38 [78]. (C) 2016 WILEY$\mathrm{VCH}$.

Four isostructural crystals $\mathrm{NaBa}_{4}\left(\mathrm{AlB}_{4} \mathrm{O}_{9}\right)_{2} \mathrm{Cl}_{3} \quad(\mathbf{3 9}), \quad \mathrm{NaBa}_{4}\left(\mathrm{GaB}_{4} \mathrm{O}_{9}\right)_{2} \mathrm{Cl}_{3} \quad$ (40), $\mathrm{NaBa}_{4}\left(\mathrm{AlB}_{4} \mathrm{O}_{9}\right)_{2} \mathrm{Br}_{3}(\mathbf{4 1})$, and $\mathrm{NaBa}_{4}\left(\mathrm{GaB}_{4} \mathrm{O}_{9}\right)_{2} \mathrm{Br}_{3}(\mathbf{4 2})$ in $\mathrm{P}_{2} \mathrm{~nm}$ space group were obtained by the high-temperature solution approach [79-83]; all feature a $3 \mathrm{D}\left[\mathrm{GaB}_{4} \mathrm{O}_{9}\right]_{\infty}$ framework composed of $\left[\mathrm{GaO}_{4}\right]$ tetrahedra and $\left[\mathrm{B}_{4} \mathrm{O}_{9}\right]$ groups (Figure 18). SHG measurements demonstrate moderate SHG responses of $0.9,1.5,0.8$, and $1.1 \times \mathrm{KDP}$ for 39-42, respectively, and they are type I phase- 
matchable. The absorption edges of $\mathbf{3 9 - 4 2}$ are in the deep-UV region, suggesting that they might be useful as UV NLO materials.
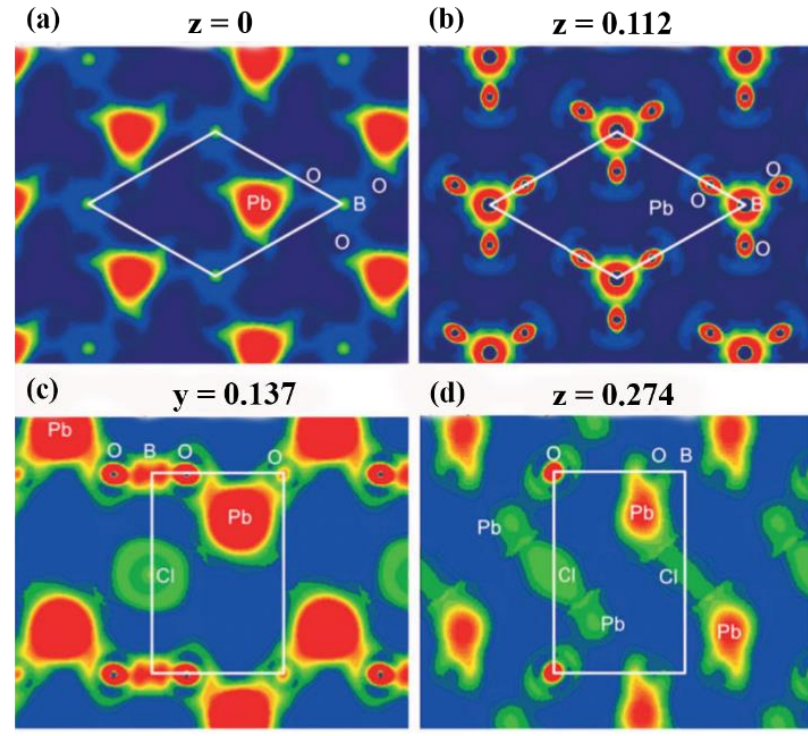

(d) $\quad \mathrm{z}=\mathbf{0 . 2 7 4}$

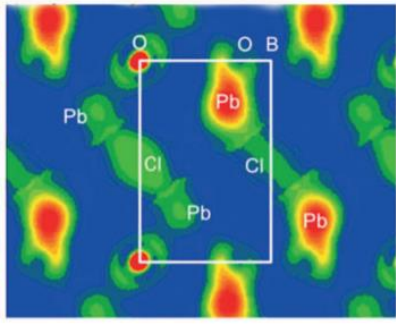

Figure 17. Electron localization function (ELF) diagrams illustrating slices along the $a b$ plane with a) $\mathrm{z}=0$ and b) $\mathrm{z}=0.112$ and slices perpendicular to the $b$ axis with c) $\mathrm{y}=0.137$ and d) $\mathrm{y}=0.274$ for 38 [78]. (C) 2016 WILEY$\mathrm{VCH}$.

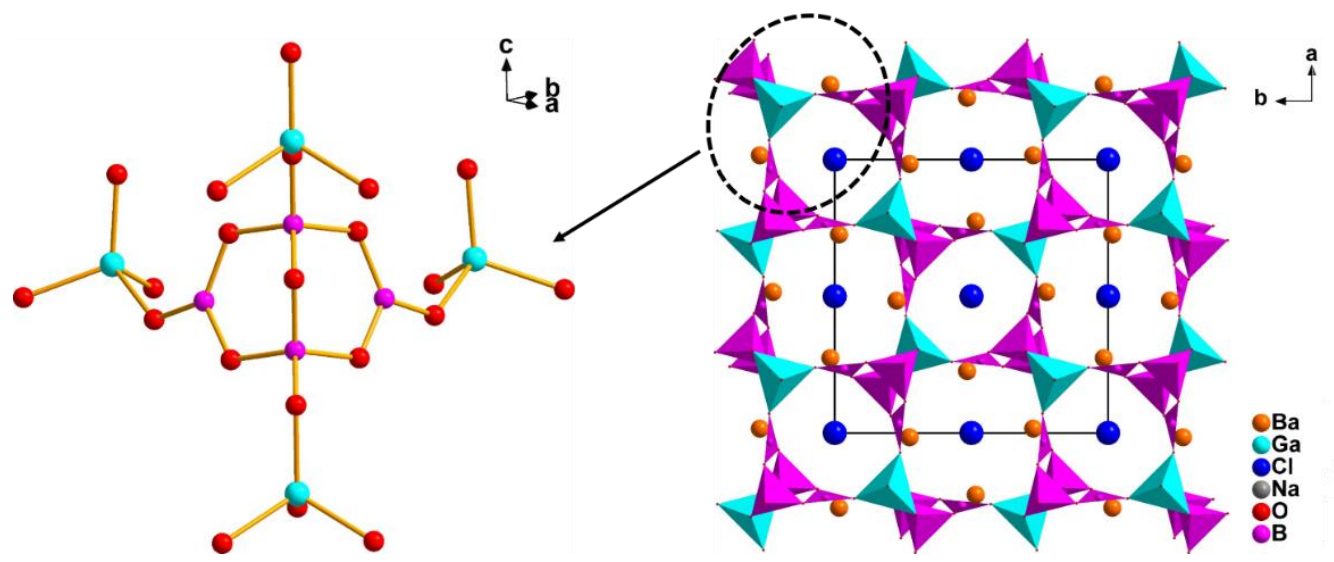

Figure 18. Crystal structure of $\mathrm{NaBa}_{4}\left(\mathrm{GaB}_{4} \mathrm{O}_{9}\right)_{2} \mathrm{X}_{3}(\mathrm{X}=\mathrm{Cl}(\mathbf{4 0}), \mathrm{Br}(42))$ [83]. (c) 2016 American Chemical Society.

$\mathrm{K}_{3} \mathrm{~B}_{6} \mathrm{O}_{10} \mathrm{X}(\mathrm{X}=\mathrm{Cl}(\mathbf{4 3}), \mathrm{Br}(\mathbf{4 4}) ; R 3 m)$, with structures analogous to perovskite, have been prepared by the flux method or the hydrothermal method [84-91]; both compounds crystallize in the same polar space group $R 3 m$, and exhibit an intricate $3 \mathrm{D}$ framework composed of $\left[\mathrm{B}_{6} \mathrm{O}_{10}\right]$ 
groups and $\left[\mathrm{XK}_{6}\right]$ octahedra (Figure 19). The two crystals possess absorption edges of $180 \mathrm{~nm}$ (43) and $184 \mathrm{~nm}(\mathbf{4 4})$, SHG measurements indicating that they are type I phase-matchable with efficiencies of ca. 3-4 times that of KDP. Their large SHG responses are attributed to the cooperative effects of the $\left[\mathrm{BO}_{3}\right]$ and $\left[\mathrm{BO}_{4}\right]$ groups and the distorted $\left[\mathrm{ClK}_{6}\right]$ octahedra. Large crystals were obtained by the TSSG method and their linear and nonlinear optical properties assessed, including refractive indices, NLO tensor components, and laser-induced damage thresholds. Substitution of the $\mathrm{K}^{+}$cations and the use of high-temperature solution reactions afforded a series of crystals with similar stoichiometry and perovskite-related structure, namely $\mathrm{Na}_{3} \mathrm{~B}_{6} \mathrm{O}_{10} \mathrm{Cl}(45)\left(P 2{ }_{1} 2_{1} 2_{1}\right), \mathrm{RbNa}_{2} \mathrm{~B}_{6} \mathrm{O}_{10} \mathrm{Cl}(46)\left(P 2_{1} 2_{1} 2_{1}\right), \mathrm{K}_{2.33} \mathrm{Na}_{0.67} \mathrm{~B}_{6} \mathrm{O}_{10} \mathrm{Br}(47)(R 3 m)$, and $\mathrm{K}_{2.87} \mathrm{Na}_{0.13} \mathrm{~B}_{6} \mathrm{O}_{10} \mathrm{Br}(\mathbf{4 8})(R 3 m)[92,93]$. All four have absorption maxima below $190 \mathrm{~nm}: 45$ and 46 exhibit weak SHG responses, while 47 and 48 gave similar SHG responses of ca. $2.8 \times$ KDP. In addition to these perovskite-type compounds, the stoichiometrically-related $\mathrm{RbNa}_{2} \mathrm{~B}_{6} \mathrm{O}_{10} \mathrm{Br}$, $\mathrm{K}_{1.7} \mathrm{Na}_{1.3} \mathrm{~B}_{6} \mathrm{O}_{10} \mathrm{Br}$, and $\mathrm{K}_{0.8} \mathrm{Na}_{2.2} \mathrm{~B}_{6} \mathrm{O}_{10} \mathrm{Br}$ crystallize in centrosymmetric (CS) space groups, the structural changes being attributed to different $\mathrm{M}-\mathrm{Br}(\mathrm{M}=\mathrm{K} / \mathrm{Na}, \mathrm{K}$, or $\mathrm{Na})$ lattice interactions.

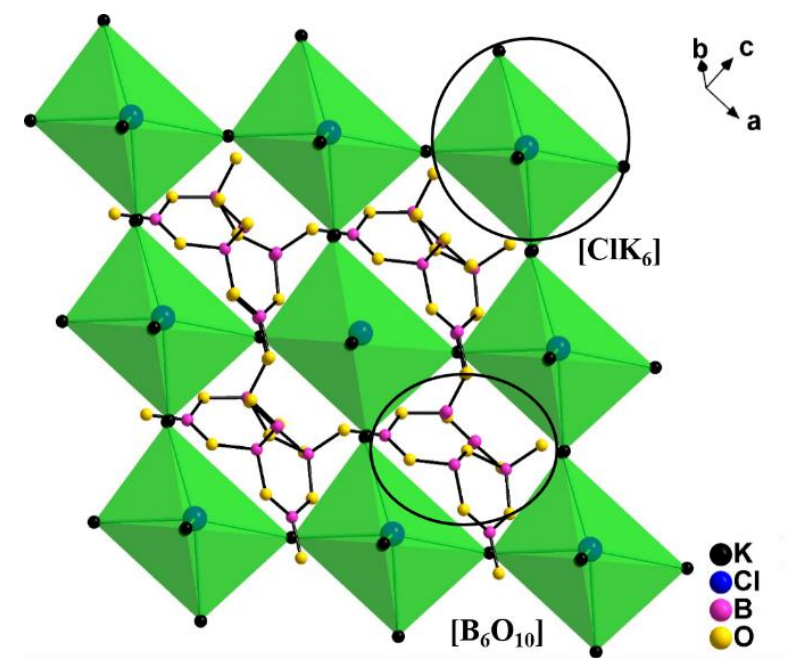

Figure 19. Crystal structure of $\mathrm{K}_{3} \mathrm{~B}_{6} \mathrm{O}_{10} \mathrm{Cl}$ (43) [91]. (c) 2011 American Chemical Society. 
The isostructural compounds $\mathrm{M}_{3} \mathrm{~B}_{6} \mathrm{O}_{11} \mathrm{~F}_{2}(\mathrm{M}=\mathrm{Ba}(\mathbf{4 9}), \mathrm{Sr}(\mathbf{5 0}), \mathrm{Pb}(\mathbf{5 1}))$ were prepared by high-temperature solution methods and crystallized in the polar space group $P 2_{1}$ [94-97]. The structure of $\mathbf{5 1}$ features a $3 \mathrm{D}$ framework composed of hexaborate $\left[\mathrm{B}_{6} \mathrm{O}_{14}\right]$ groups and $\left[\mathrm{FPb}_{3}\right]_{\infty}$ layers (Figure 20). All three compounds possess moderate SHG responses and are phasematchable, their SHG efficiencies being ca. 2.5, 3, and $4 \times \mathrm{KDP}$ for the $\mathrm{Sr}, \mathrm{Ba}$, and $\mathrm{Pb}$ examples, respectively. They also possess wide transparency ranges; in particular, 49 and $\mathbf{5 0}$ exhibit UV absorption edges below $190 \mathrm{~nm}$.

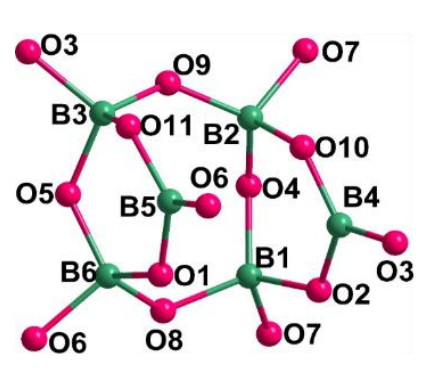

(a)

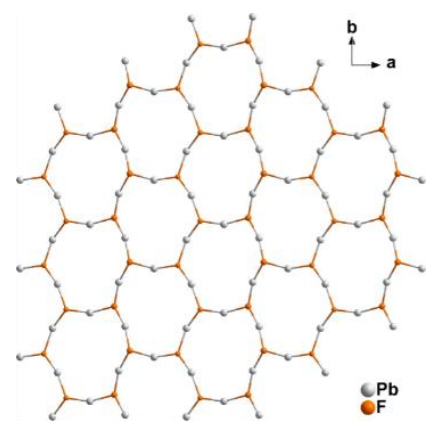

(b)

(c)

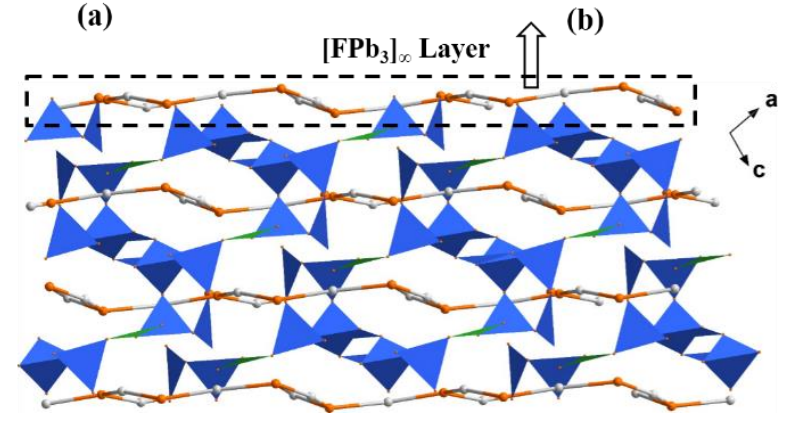

Figure 20. (a) The $\left[\mathrm{B}_{6} \mathrm{O}_{14}\right]$ group and (b) the $\left[\mathrm{FPb}_{3}\right]_{\infty}$ layer. (c) Crystal structure of $\mathbf{5 1}\left(\mathrm{BO}_{3}\right.$, green; $\mathrm{BO}_{4}$, blue) [96]. ( 2014 Royal Society of Chemistry.

The polar material $\mathrm{Ba}_{4} \mathrm{~B}_{11} \mathrm{O}_{20} \mathrm{~F}(\mathbf{5 2})\left(C m c 2_{1}\right)$ was obtained by introducing fluorine into $\mathrm{BBO}$ [98]. Polycrystalline $\mathbf{5 2}$ was synthesized by the HTSS reaction, single crystals being subsequently obtained from a high-temperature solution. $\mathbf{5 2}$ displays a complex 3D anionic framework structure consisting of $\left[\mathrm{B}_{11} \mathrm{O}_{24}\right]$ FBUs and $\mathrm{Ba}-\mathrm{F}-\mathrm{Ba}$ chains (Figure 21). Particularly noteworthy is that $\mathbf{5 2}$ possesses the largest SHG response $(10 \times \mathrm{KDP})$ of all borates containing neither lone-pair-active anions nor second-order Jahn-Teller-active transition metals. The enhanced SHG intensity in $\mathbf{5 2}$ 
mainly originates from F-directed polar displacements and to a lesser extent from the $\mathrm{Ba}$ polarizability (Figure 22) based upon ELF calculations by the DFT method. In addition, 52 also has a deep-UV absorption edge at $175 \mathrm{~nm}$.

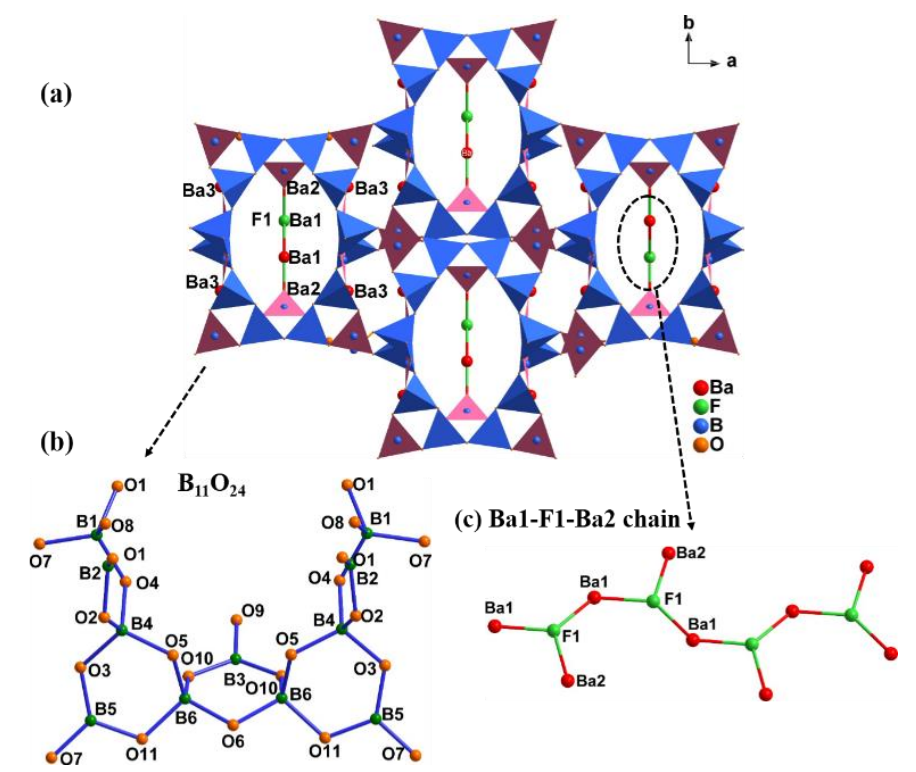

Figure 21. (a) Crystal structure of $\mathrm{Ba}_{4} \mathrm{~B}_{11} \mathrm{O}_{20} \mathrm{~F}$ (52) ( $\mathrm{BO}_{4}$ groups, light blue; $\mathrm{BO}_{3}$ groups, pink). (b) $\left[\mathrm{B}_{11} \mathrm{O}_{24}\right]$ FBU. (c) Ba1-F1-Ba2 chain [98]. @ 2013 American Chemical Society.

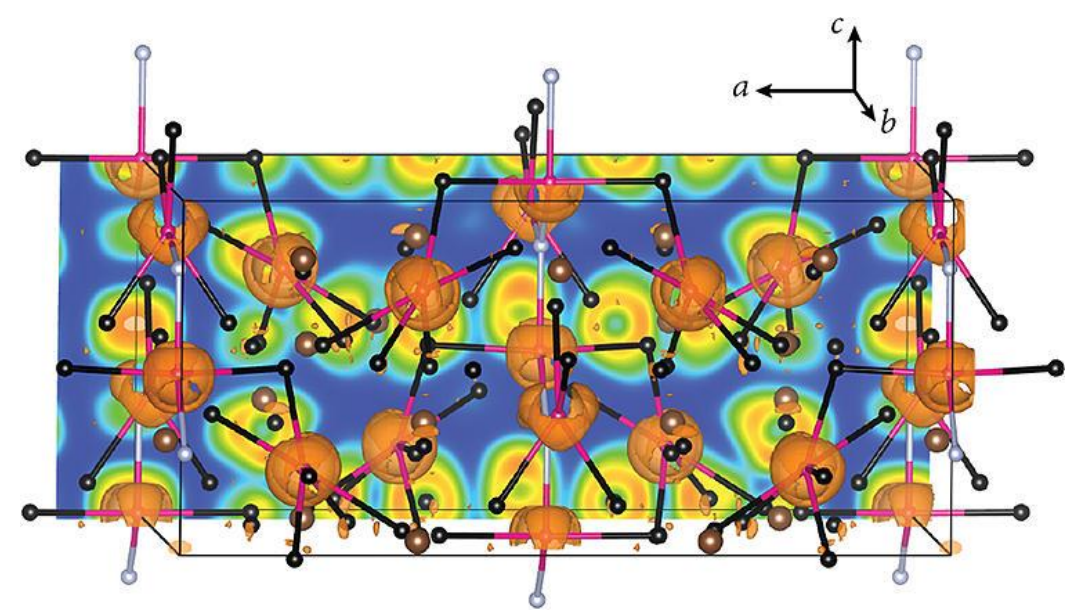

Figure 22. ELF isosurface plot for $\mathbf{5 2}$ showing the asymmetric charge localization (orange lobes) mainly about the $\mathrm{Ba} 2$ and $\mathrm{Ba} 3$ sites. Ba pink, O black, F gray; B has been omitted for clarity [98]. ( 2013 American Chemical Society.

$\mathrm{Li}_{2} \mathrm{~B}_{6} \mathrm{O}_{9} \mathrm{~F}_{2}(53)$ was prepared by a HTSS reaction under vacuum. It crystallizes in the monoclinic space group $C c$ and possesses the functional building block $\left[\mathrm{B}_{6} \mathrm{O}_{9} \mathrm{~F}_{2}\right]$, which is 
composed of $\left[\mathrm{BO}_{3}\right],\left[\mathrm{BO}_{4}\right]$ and $\left[\mathrm{BO}_{2} \mathrm{~F}_{2}\right]$ moieties (Figure 23). 53 shows a moderate SHG efficiency $(0.9 \times \mathrm{KDP})$ with an absorption edge below $190 \mathrm{~nm}$, in addition to a large birefringence of 0.07 . Computational studies by the plane-wave DFT method suggest that introducing $\left[\mathrm{BO}_{3} \mathrm{~F}\right],\left[\mathrm{BO}_{2} \mathrm{~F}_{2}\right]$, and $\left[\mathrm{BOF}_{3}\right]$ groups into borates (e.g. $\left.\mathrm{LiB}_{6} \mathrm{O}_{9} \mathrm{~F}, \mathrm{Li}_{2} \mathrm{~B}_{6} \mathrm{O}_{9} \mathrm{~F}_{2}, \mathrm{Li}_{2} \mathrm{~B}_{3} \mathrm{O}_{4} \mathrm{~F}_{3}\right)$ is the key to achieving a large birefringence and simultaneously an absorption edge in the deep-UV region (Figure 24) [99,100]. This strategy may provide a universal and feasible way to design and synthesize applicable deep-UV NLO materials.

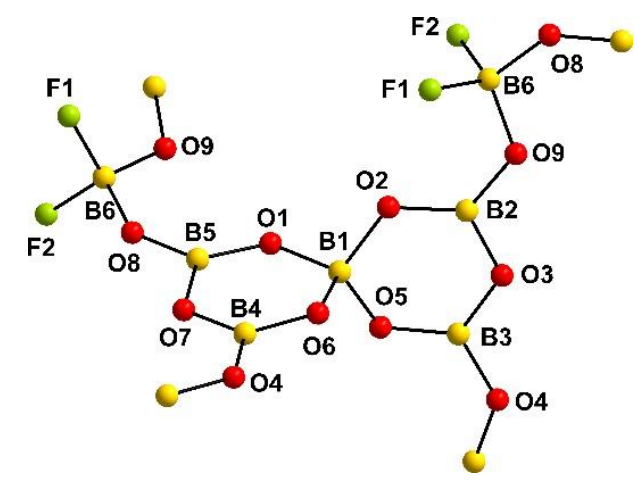

Figure 23. The anionic network of $\mathrm{Li}_{2} \mathrm{~B}_{6} \mathrm{O}_{9} \mathrm{~F}_{2}(\mathbf{5 3})$ consisting of the fundamental building block $\left[\mathrm{B}_{6} \mathrm{O}_{9} \mathrm{~F}_{2}\right]$ [99]. (c) 2011 WILEY-VCH.

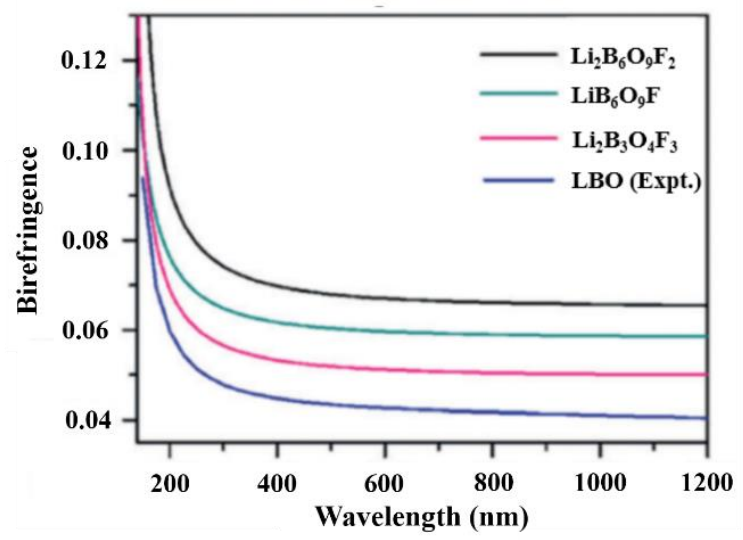

Figure 24. The birefringence of $\mathrm{Li}_{2} \mathrm{~B}_{6} \mathrm{O}_{9} \mathrm{~F}_{2}(\mathbf{5 3}), \mathrm{LiB}_{6} \mathrm{O}_{9} \mathrm{~F}, \mathrm{Li}_{2} \mathrm{~B}_{3} \mathrm{O}_{4} \mathrm{~F}_{3}$, and the experimental value of $\mathrm{LBO}$ [99]. (c) 2011 WILEY-VCH.

The NCS metal-halide borate $\mathrm{BaClBF}_{4}(\mathbf{5 4})\left(P m n 2_{1}\right)$ was synthesized by the hydrothermal method affording crystals up to $6 \times 6 \times 3 \mathrm{~mm}$ in size [101]. The crystal structure consists of 
alternating layers of pseudo-aurivillius-type $\left[\mathrm{Ba}_{2} \mathrm{Cl}_{2}\right]$ and anionic $\left[\mathrm{BF}_{4}\right]$. The absorption edge is ca. $180 \mathrm{~nm}$ and the SHG response is about 0.2 times that of $\mathrm{KDP}$. The $\left[\mathrm{BF}_{4}\right]$ tetrahedron is similar to $\left[\mathrm{BO}_{4}\right]$ tetrahedra in borate in contributing little to the overall SHG efficiency.

Metal borates containing halogen anions are an important member of borates family, which process high probability of NCS structures, large SHG responses and short absorption edges. The growth of large size single-crystal of metal borates containing halogen anions is still a great challenge. These understandings are critical to the design of new deep-UV second-order NLO materials. Based on the above requirements, the reported metal borates containing halogen anions, such as $\mathrm{KZn}_{2} \mathrm{BO}_{3} \mathrm{Cl}_{2}, \mathrm{RbZn}_{2} \mathrm{BO}_{3} \mathrm{Cl}_{2}, \mathrm{KZn}_{2} \mathrm{BO}_{3} \mathrm{Br}_{2}, \mathrm{RbZn}_{2} \mathrm{BO}_{3} \mathrm{Br}_{2}, \mathrm{BaMgBO}_{3} \mathrm{~F}, \mathrm{BaZnBO}_{3} \mathrm{~F}$, $\mathrm{K}_{3} \mathrm{Ba}_{3} \mathrm{Li}_{2} \mathrm{Al}_{4} \mathrm{~B}_{6} \mathrm{O}_{20} \mathrm{~F}$, and $\mathrm{Li}_{2} \mathrm{~B}_{6} \mathrm{O}_{9} \mathrm{~F}$, are the potential candidates for the UV and deep-UV NLO applications. In addition, some other optical characters (e.g. refractive indices, birefringences) are also the concern for the pratical optical-quality crystals.

\subsection{Hydrated metal borates}

The hydrothermal method, solvothermal method and solution evaporation method are the conventional routes to synthesize hydrated borates. Varying the reaction conditions (e.g. modifying the reaction temperature, counterion, concentration of boron in the solution, and the $\mathrm{pH}$ value of the reaction media) can afford metal borates with a range of structures, including discrete B-O clusters, infinite chains, sheets, and 3D frameworks [102-106]. In the process, many NCS crystals with excellent SHG properties have been discovered (Table 3).

The structure of $\mathrm{Na}_{0.33} \mathrm{~K}_{1.67}\left(\mathrm{~B}_{4} \mathrm{O}_{5}\right)(\mathrm{OH})_{4} \cdot 3 \mathrm{H}_{2} \mathrm{O}(\mathbf{5 5})(P \overline{6} 2 c)$ features a 3D supramolecular framework consisting of isolated $\left[\mathrm{B}_{4} \mathrm{O}_{9}\right]$ primary building units connected by H-bonding interactions and $\mathrm{K}-\mathrm{O}$ and $\mathrm{Na}-\mathrm{O}$ bonds [107]. SHG measurements show that $\mathbf{5 5}$ is type I phasematchable with a moderate SHG response (ca. $0.94 \times \mathrm{KDP}$ ) and an absorption edge below $190 \mathrm{~nm}$. 
Varying the polar organic solvents employed in the solvothermal synthesis resulted in significant diversity in the framework structures [107]. $\mathrm{K}_{2}\left[\mathrm{~B}_{4} \mathrm{O}_{5}(\mathrm{OH})_{4}\right] \cdot 2 \mathrm{H}_{2} \mathrm{O}$ (56) $\left(P 2{ }_{1} 2_{1} 2_{1}\right)$ [108], $\mathrm{Cs}_{2} \mathrm{Ca}\left[\mathrm{B}_{4} \mathrm{O}_{5}(\mathrm{OH})_{4}\right]_{2} \cdot 8 \mathrm{H}_{2} \mathrm{O}(\mathbf{5 7})\left(P 2_{1} 2_{1} 2_{1}\right)[109]$, and $\mathrm{K}_{2} \mathrm{Ba}\left[\mathrm{B}_{4} \mathrm{O}_{5}(\mathrm{OH})_{4}\right]_{2} \cdot 10 \mathrm{H}_{2} \mathrm{O}(\mathbf{5 8})\left(P n a 2_{1}\right)[110]$ were prepared by the slow evaporation method. These three crystals possess the same primary building block $\left[\mathrm{B}_{4} \mathrm{O}_{9}\right]$ as $\mathbf{5 5}$ but crystallize in different NCS space groups. The absorption edges for three crystals are all below $200 \mathrm{~nm}$. All three compounds are phase-matchable with SHG efficiency of ca. $0.5 \times \mathrm{KDP}$.

\section{Table 3}

NLO data for hydrated metal borates.

\begin{tabular}{|c|c|c|c|c|c|}
\hline Compounds & $\begin{array}{l}\text { Space } \\
\text { group }\end{array}$ & $\begin{array}{l}\text { Structural } \\
\text { feature }\end{array}$ & Absorption edge & $\begin{array}{l}\text { SHG intensity } \\
(@ 1064 \text { nm) }\end{array}$ & Ref. \\
\hline $\mathrm{Na}_{0.33} \mathrm{~K}_{1.67}\left(\mathrm{~B}_{4} \mathrm{O}_{5}\right)(\mathrm{OH})_{4} \cdot 3 \mathrm{H}_{2} \mathrm{O}$ & $P \overline{6} 2 c$ & {$\left[\mathrm{~B}_{4} \mathrm{O}_{9}\right]$} & $242 \mathrm{~nm}(5.13 \mathrm{eV})^{a}$ & $0.94 \times \mathrm{KDP}$ & [107] \\
\hline $\mathrm{K}_{2}\left[\mathrm{~B}_{4} \mathrm{O}_{5}(\mathrm{OH})_{4}\right] \cdot 2 \mathrm{H}_{2} \mathrm{O}$ & $P 2{ }_{1}{ }_{1} 2_{1}$ & {$\left[\mathrm{~B}_{4} \mathrm{O}_{9}\right]$} & $180 \mathrm{~nm}(6.89 \mathrm{eV})$ & $0.5 \times \mathrm{KDP}$ & [108] \\
\hline $\mathrm{Cs}_{2} \mathrm{Ca}\left[\mathrm{B}_{4} \mathrm{O}_{5}(\mathrm{OH})_{4}\right]_{2} \cdot 8 \mathrm{H}_{2} \mathrm{O}$ & $P 2{ }_{1}{ }_{1} 2_{1}$ & {$\left[\mathrm{~B}_{4} \mathrm{O}_{9}\right]$} & $190 \mathrm{~nm}(>6.53 \mathrm{eV})$ & $0.5 \times \mathrm{KDP}$ & [109] \\
\hline $\mathrm{K}_{2} \mathrm{Ba}\left[\mathrm{B}_{4} \mathrm{O}_{5}(\mathrm{OH})_{4}\right]_{2} \cdot 10 \mathrm{H}_{2} \mathrm{O}$ & $\operatorname{Pna}_{1}$ & {$\left[\mathrm{~B}_{4} \mathrm{O}_{9}\right]$} & $<200 \mathrm{~nm}(>6.2 \mathrm{eV})$ & $0.5 \times \mathrm{KDP}$ & [110] \\
\hline $\mathrm{Li}\left(\mathrm{H}_{2} \mathrm{O}\right)_{4} \mathrm{~B}(\mathrm{OH})_{4} \cdot 2 \mathrm{H}_{2} \mathrm{O}$ & $P 3$ & {$\left[\mathrm{BO}_{4}\right]$} & $262 \mathrm{~nm}(4.73 \mathrm{eV})$ & $0.8 \times \mathrm{KDP}$ & [112] \\
\hline $\mathrm{K}_{3} \mathrm{~B}_{3} \mathrm{O}_{4}(\mathrm{OH})_{4} \cdot 2 \mathrm{H}_{2} \mathrm{O}$ & $\mathrm{Cmc} 2_{1}$ & {$\left[\mathrm{~B}_{3} \mathrm{O}_{8}\right]$} & $<190 \mathrm{~nm}(>6.53 \mathrm{eV})$ & $0.8 \times \mathrm{KDP}$ & [111] \\
\hline $\mathrm{Na}\left[\mathrm{B}_{5} \mathrm{O}_{7}(\mathrm{OH})_{2}\right]\left(\mathrm{H}_{2} \mathrm{O}\right)$ & $\operatorname{Pca}_{1}$ & {$\left[\mathrm{~B}_{5} \mathrm{O}_{10}\right]$} & $221 \mathrm{~nm}(5.61 \mathrm{eV})^{a}$ & $0.1 \times \mathrm{KDP}$ & [113] \\
\hline $\mathrm{Ba}_{2}\left[\mathrm{~B}_{4} \mathrm{O}_{7}(\mathrm{OH})_{2}\right]$ & $P 3{ }_{1} 21$ & {$\left[\mathrm{~B}_{5} \mathrm{O}_{13}\right]$} & $242 \mathrm{~nm}(5.12 \mathrm{eV})^{a}$ & $2.2 \times \mathrm{KDP}$ & [113] \\
\hline $\begin{array}{l}\mathrm{Ba}_{2}\left[\mathrm{~B}_{6} \mathrm{O}_{9}(\mathrm{OH})_{2}\right]\left[\mathrm{B}_{3} \mathrm{O}_{3}(\mathrm{OH})_{4}\right] \cdot \\
(\mathrm{OH}) \cdot 4 \mathrm{H}_{2} \mathrm{O}\end{array}$ & $P m n 2_{1}$ & $\begin{array}{l}{\left[\mathrm{B}_{3} \mathrm{O}_{7}\right]} \\
{\left[\mathrm{B}_{6} \mathrm{O}_{13}\right]}\end{array}$ & $230 \mathrm{~nm}(5.40 \mathrm{eV})^{a}$ & $0.8 \times \mathrm{KDP}$ & [114] \\
\hline $\mathrm{Na}_{2} \mathrm{~B}_{5} \mathrm{O}_{8}(\mathrm{OH}) \cdot 2 \mathrm{H}_{2} \mathrm{O}$ & Pna $2_{1}$ & {$\left[\mathrm{~B}_{5} \mathrm{O}_{9}\right]$} & $<190 \mathrm{~nm}(>6.53 \mathrm{eV})$ & $0.5 \times \mathrm{KDP}$ & [116] \\
\hline $\mathrm{Ca}_{2}\left[\mathrm{~B}_{5} \mathrm{O}_{8}(\mathrm{OH})\right]_{2}\left[\mathrm{~B}(\mathrm{OH})_{3}\right] \mathrm{H}_{2} \mathrm{O}$ & $P 2_{1}$ & {$\left[\mathrm{~B}_{5} \mathrm{O}_{11}\right]$} & $223 \mathrm{~nm}(5.55 \mathrm{eV})^{a}$ & $1.3 \times \mathrm{KDP}$ & [114] \\
\hline $\mathrm{Ba}_{2}\left[\mathrm{~B}_{6} \mathrm{O}_{9}(\mathrm{OH})_{4}\right]$ & $P 2_{1}$ & {$\left[\mathrm{~B}_{6} \mathrm{O}_{13}\right]$} & $<190 \mathrm{~nm}(>6.53 \mathrm{eV})$ & $3.0 \times \mathrm{KDP}$ & [115] \\
\hline $\mathrm{Mg}\left[\mathrm{B}_{6} \mathrm{O}_{9}(\mathrm{OH})_{2}\right] \cdot 4 \mathrm{H}_{2} \mathrm{O}$ & Pna $2_{1}$ & {$\left[\mathrm{~B}_{6} \mathrm{O}_{13}\right]$} & $<200 \mathrm{~nm}(>6.2 \mathrm{eV})$ & $1.1 \times \mathrm{KDP}$ & [117] \\
\hline $\mathrm{Na}_{2} \mathrm{~B}_{9} \mathrm{O}_{15}\left(\mathrm{H}_{2} \mathrm{O}\right)\left(\mathrm{H}_{3} \mathrm{O}\right)$ & $P 2_{1}$ & $\begin{array}{l}{\left[\mathrm{B}_{3} \mathrm{O}_{7}\right]} \\
{\left[\mathrm{B}_{6} \mathrm{O}_{13}\right]}\end{array}$ & $286 \mathrm{~nm}(4.33 \mathrm{eV})^{a}$ & $1.0 \times \mathrm{KDP}$ & [118] \\
\hline $\mathrm{Ba}_{3} \mathrm{Al}_{2}\left[\mathrm{~B}_{3} \mathrm{O}_{6}(\mathrm{OH})\right]_{2}\left[\mathrm{~B}_{4} \mathrm{O}_{7}(\mathrm{OH})_{2}\right]$ & $F d d 2$ & $\begin{array}{l}{\left[\mathrm{B}_{3} \mathrm{O}_{7}\right],} \\
{\left[\mathrm{B}_{4} \mathrm{O}_{9}\right]}\end{array}$ & $230 \mathrm{~nm}(5.4 \mathrm{eV})^{a}$ & $3.0 \times \mathrm{KDP}$ & [126] \\
\hline $\mathrm{Ba}_{3} \mathrm{Ga}_{2}\left[\mathrm{~B}_{3} \mathrm{O}_{6}(\mathrm{OH})\right]_{2}\left[\mathrm{~B}_{4} \mathrm{O}_{7}(\mathrm{OH})_{2}\right]$ & $F d d 2$ & $\begin{array}{l}{\left[\mathrm{B}_{3} \mathrm{O}_{7}\right]} \\
{\left[\mathrm{B}_{4} \mathrm{O}_{9}\right]}\end{array}$ & $248 \mathrm{~nm}(5.0 \mathrm{eV})^{a}$ & $3.0 \times \mathrm{KDP}$ & [126] \\
\hline $\mathrm{Sr}_{2} \mathrm{~B}_{5} \mathrm{O}_{9}(\mathrm{OH}) \cdot \mathrm{H}_{2} \mathrm{O}$ & $C 2$ & {$\left[\mathrm{~B}_{5} \mathrm{O}_{11}\right]$} & $<190 \mathrm{~nm}(>6.53 \mathrm{eV})$ & $3.0 \times \mathrm{KDP}$ & [122] \\
\hline
\end{tabular}




\begin{tabular}{llllll}
$\mathrm{Ca}_{2}\left[\mathrm{~B}_{5} \mathrm{O}_{9}\right] \cdot(\mathrm{OH}) \cdot \mathrm{H}_{2} \mathrm{O}$ & $C c$ & {$\left[\mathrm{~B}_{5} \mathrm{O}_{12}\right]$} & $228 \mathrm{~nm}(5.45 \mathrm{eV})^{a}$ & $3.0 \times \mathrm{KDP}$ & {$[119]$} \\
$\mathrm{Ba}_{2} \mathrm{~B}_{5} \mathrm{O}_{9} \mathrm{Cl} \cdot 0.5 \mathrm{H}_{2} \mathrm{O}$ & $P n n 2$ & {$\left[\mathrm{~B}_{5} \mathrm{O}_{12}\right]$} & $225 \mathrm{~nm}(5.5 \mathrm{eV})^{a}$ & $1.0 \times \mathrm{KDP}$ & {$[120]$} \\
$\mathrm{Ba}_{2.16} \mathrm{~Pb}_{0.84}(\mathrm{OH})\left(\mathrm{B}_{9} \mathrm{O}_{16}\right)\left[\mathrm{B}(\mathrm{OH})_{3}\right]$ & $P 31 c$ & {$\left[\mathrm{~B}_{9} \mathrm{O}_{19}\right]$} & $266 \mathrm{~nm}(4.65 \mathrm{eV})$ & $1.2 \times \mathrm{KDP}$ & {$[123]$} \\
$\mathrm{Ba}_{3}(\mathrm{OH})\left(\mathrm{B}_{9} \mathrm{O}_{16}\right)\left[\mathrm{B}(\mathrm{OH})_{3}\right]$ & $P 31 c$ & {$\left[\mathrm{~B}_{9} \mathrm{O}_{19}\right]$} & $243 \mathrm{~nm}(5.11 \mathrm{eV})$ & $1.1 \times \mathrm{KDP}$ & {$[123]$} \\
$\mathrm{LiBa}_{3}(\mathrm{OH})\left[\mathrm{B}_{9} \mathrm{O}_{16}\right]\left[\mathrm{B}(\mathrm{OH})_{4}\right]$ & $P 31 c$ & {$\left[\mathrm{~B}_{9} \mathrm{O}_{19}\right]$} & $<200 \mathrm{~nm}(>6.2 \mathrm{eV})$ & $1.2 \times \mathrm{KDP}$ & {$[124,125]$} \\
$\mathrm{Sr}_{4} \mathrm{~B}_{10} \mathrm{O}_{18}(\mathrm{OH})_{2} \cdot 2 \mathrm{H}_{2} \mathrm{O}$ & $P 1$ & {$\left[\mathrm{~B}_{10} \mathrm{O}_{23}\right]$} & $<190 \mathrm{~nm}(>6.53 \mathrm{eV})$ & $2.0 \times \mathrm{KDP}$ & {$[121]$} \\
\hline
\end{tabular}

${ }^{a}$ Energy bandgap.

$\mathrm{K}_{3} \mathrm{~B}_{3} \mathrm{O}_{4}(\mathrm{OH})_{4} \cdot 2 \mathrm{H}_{2} \mathrm{O}(\mathbf{5 9})$ was synthesized by a hydrothermal reaction of a mixture of $\mathrm{Rb}_{2} \mathrm{CO}_{3}$, $\mathrm{H}_{3} \mathrm{BO}_{3}, \mathrm{KOH}$, and distilled water. 59 crystallizes in space group $C m c 2_{1}$ and exhibits isolated $\left[\mathrm{B}_{3} \mathrm{O}_{8}\right]$ anion groups connected by hydrogen bonds [111]. The mateiral has a wide transparency range with an absorption edge below $190 \mathrm{~nm}$. SHG measurements reveal a moderate efficiency of $0.8 \times$ KDP with type I phase-matchable. Theoretical calculations by SHG-density method suggest that the dominant contribution to SHG comes from the borate groups and the lattice water. Crystals of $\mathrm{Li}\left(\mathrm{H}_{2} \mathrm{O}\right)_{4} \mathrm{~B}(\mathrm{OH})_{4} \cdot 2 \mathrm{H}_{2} \mathrm{O}(\mathbf{6 0})(P 3)$ were also obtained by hydrothermal means. The structure of $\mathbf{6 0}$ is composed of $\left[\mathrm{BO}_{4}\right]$ tetrahedra, $\mathrm{Li}\left(\mathrm{H}_{2} \mathrm{O}\right)_{4}$ tetrahedra and isolated water molecules [112]. Its absorption edge is close to the deep-UV and its SHG response is about $0.8 \times \mathrm{KDP}$. Dipole moment calculations suggest that the SHG response originates from a cooperative effect of $\left[\mathrm{BO}_{4}\right]$ and $\left[\mathrm{LiO}_{4}\right]$ units along the $c$-axis.

$\mathrm{Ba}_{2}\left[\mathrm{~B}_{4} \mathrm{O}_{7}(\mathrm{OH})_{2}\right](61)$ and $\mathrm{Na}\left[\mathrm{B}_{5} \mathrm{O}_{7}(\mathrm{OH})_{2}\right]\left(\mathrm{H}_{2} \mathrm{O}\right)(62)$ crystallize in the space groups $P c a 2_{1}$ and $P 3_{1} 21$, respectively [113]. The structure of $\mathbf{6 1}$ consists of $1 \mathrm{D}$ borate chains formed by [ $\left.\mathrm{B}_{3} \mathrm{O}_{9}\right]$ and $\left[\mathrm{B}_{3} \mathrm{O}_{8}\right]$ rings, which further assemble into a $3 \mathrm{D}$ framework with $\mathrm{Ba}^{2+}$ cations (Figure $25 \mathrm{a}$ ). The structure of $\mathbf{6 2}$ exhibits double helical chains constructed from $\left[\mathrm{B}_{5} \mathrm{O}_{10}\right]$ primary building units, which are interconnected via $\mathrm{Na}^{+}$cations and $\mathrm{H}$-bonding interactions to generate a $3 \mathrm{D}$ framework (Figure 25b). 61 shows type I phase-matchable behavior with SHG response of $2.2 \times \mathrm{KDP}$, while 62 exhibits a weak SHG response. The energy bandgaps of $\mathbf{6 1}$ and $\mathbf{6 2}$ are 5.12 and $5.61 \mathrm{eV}$, 
respectively. $\mathbf{6 2}$ is the first example of an SHG-active metal borate crystal synthesized under surfactant-thermal conditions, and such a synthetic method provides an additional effective route to new SHG-active metal borates.

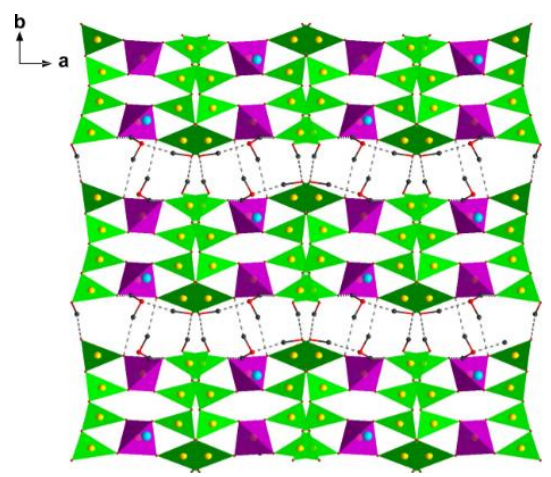

(a)

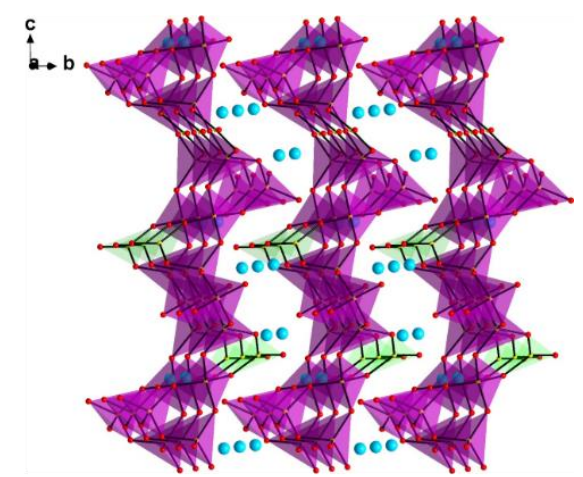

(b)

Figure 25. Crystal structures of (a) $\mathrm{Na}_{2}\left[\mathrm{~B}_{5} \mathrm{O}_{7}(\mathrm{OH})_{2}\right]\left(\mathrm{H}_{2} \mathrm{O}\right)(62)$ and (b) $\mathrm{Ba}_{2}\left[\mathrm{~B}_{4} \mathrm{O}_{7}(\mathrm{OH})_{2}\right](6 \mathbf{6 1})$. (Color codes: gold for $\mathrm{B}$, red for $\mathrm{O}$, blue for $\mathrm{Na}$, black for $\mathrm{H}$, green triangles for $\left[\mathrm{BO}_{3}\right]$, and purple tetrahedra for [ $\left.\mathrm{BO}_{4}\right]$ ) [113]. (C) 2017 American Chemical Society.

Hydrated borates with 2D structures include $\mathrm{Ca}_{2}\left[\mathrm{~B}_{5} \mathrm{O}_{8}(\mathrm{OH})\right]_{2}\left[\mathrm{~B}(\mathrm{OH})_{3}\right] \mathrm{H}_{2} \mathrm{O}(\mathbf{6 3})\left(P 2_{1}\right)$ [114], $\mathrm{Ba}_{2}\left[\mathrm{~B}_{6} \mathrm{O}_{9}(\mathrm{OH})_{2}\right]\left[\mathrm{B}_{3} \mathrm{O}_{3}(\mathrm{OH})_{4}\right] \cdot(\mathrm{OH}) \cdot 4 \mathrm{H}_{2} \mathrm{O}(\mathbf{6 4})\left(P m n 2_{1}\right)[114], \mathrm{Ba}_{2}\left[\mathrm{~B}_{6} \mathrm{O}_{9}(\mathrm{OH})_{4}\right](65)\left(P 2_{1}\right)[115]$, $\mathrm{Na}_{2} \mathrm{~B}_{5} \mathrm{O}_{8}(\mathrm{OH}) \cdot 2 \mathrm{H}_{2} \mathrm{O}\left(\right.$ (66) (Pna $\left.2_{1}\right)$ [116], and $\mathrm{Mg}\left[\mathrm{B}_{6} \mathrm{O}_{9}(\mathrm{OH})_{2}\right] \cdot 4 \mathrm{H}_{2} \mathrm{O}$ (67) (Pna2 $2_{1}$ ) [117], all hydrothermally synthesized under autogenous pressure. The structure of $\mathbf{6 5}$ is interesting, containing chiral layers constructed of two kinds of helical chains forming $\left[\mathrm{B}_{18} \mathrm{O}_{42}\right]$ circles (Figure 26); it has an absorption edge below $190 \mathrm{~nm}$ and exhibits a SHG response ca. $3 \times \mathrm{KDP}$ with type I phase-matchable behavior. The structure of $\mathbf{6 6}$ is also of interest, being assembled from $\mathrm{Na}-\mathrm{O}$ polyhedra and $\left[\mathrm{B}_{5} \mathrm{O}_{9}\right]$ polyborate anions. Moderately large $\left(5 \times 5 \times 3 \mathrm{~mm}^{3}\right)$ single crystals were grown under mild hydrothermal conditions, while it shows an absorption edge less than $190 \mathrm{~nm}$ in the deep-UV region. SHG measurements revealed type I phase-matchable behavior with an efficiency ca. $0.5 \times \mathrm{KDP}$. 

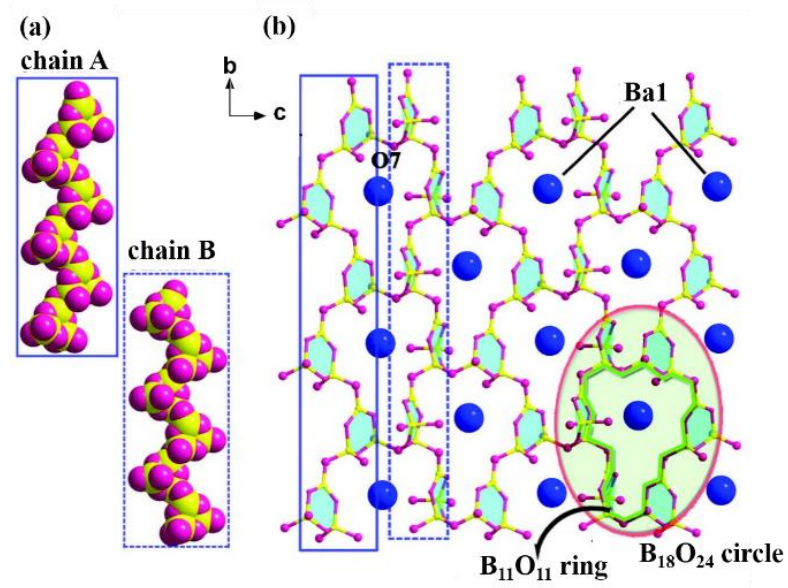

Figure 26. (a) Space-filling model showing the two kinds of helical chain structures of $\mathrm{Ba}_{2}\left[\mathrm{~B}_{6} \mathrm{O}_{9}(\mathrm{OH})_{4}\right](\mathbf{6 5})$ along the $b c$ and $a b$ planes. (b) Homochiral layer parallel to the $b c$ plane [115]. (c) 2017 American Chemical Society.

A range of hydrated borates with 3D structures have also been prepared by hydrothermal/solvothermal methods, including $\mathrm{Na}_{2} \mathrm{~B}_{9} \mathrm{O}_{15}\left(\mathrm{H}_{2} \mathrm{O}\right)\left(\mathrm{H}_{3} \mathrm{O}\right)$ (68) (P2 $\left.2_{1}\right)$ [118], $\mathrm{Ca}_{2}\left[\mathrm{~B}_{5} \mathrm{O}_{9}\right] \cdot(\mathrm{OH}) \cdot \mathrm{H}_{2} \mathrm{O} \quad(\mathbf{6 9}) \quad(C c) \quad[119], \quad \mathrm{Ba}_{2} \mathrm{~B}_{5} \mathrm{O}_{9} \mathrm{Cl} \cdot 0.5 \mathrm{H}_{2} \mathrm{O} \quad(\mathbf{7 0}) \quad(P n n 2) \quad[120]$, $\mathrm{Sr}_{4} \mathrm{~B}_{10} \mathrm{O}_{18}(\mathrm{OH})_{2} \cdot 2 \mathrm{H}_{2} \mathrm{O} \quad(\mathbf{7 1}) \quad(P 1) \quad[121], \quad \mathrm{Sr}_{2} \mathrm{~B}_{5} \mathrm{O}_{9}(\mathrm{OH}) \cdot \mathrm{H}_{2} \mathrm{O} \quad$ (72) $\quad(C 2) \quad[122]$, $\mathrm{Ba}_{3}(\mathrm{OH})\left(\mathrm{B}_{9} \mathrm{O}_{16}\right)\left[\mathrm{B}(\mathrm{OH})_{3}\right](\mathbf{7 3})(P 31 c)[123], \mathrm{LiBa}_{3}(\mathrm{OH})\left[\mathrm{B}_{9} \mathrm{O}_{16}\right]\left[\mathrm{B}(\mathrm{OH})_{4}\right](\mathbf{7 4})(P 31 c)[124,125]$, $\mathrm{Ba}_{3} \mathrm{Al}_{2}\left[\mathrm{~B}_{3} \mathrm{O}_{6}(\mathrm{OH})\right]_{2}\left[\mathrm{~B}_{4} \mathrm{O}_{7}(\mathrm{OH})_{2}\right](\mathbf{7 5})(F d d 2)[126], \mathrm{Ba}_{3} \mathrm{Ga}_{2}\left[\mathrm{~B}_{3} \mathrm{O}_{6}(\mathrm{OH})\right]_{2}\left[\mathrm{~B}_{4} \mathrm{O}_{7}(\mathrm{OH})_{2}\right](F d d 2)(\mathbf{7 6})$ [126], and $\mathrm{Ba}_{2.16} \mathrm{~Pb}_{0.84}(\mathrm{OH})\left(\mathrm{B}_{9} \mathrm{O}_{16}\right)\left[\mathrm{B}(\mathrm{OH})_{3}\right](77)(P 31 c)$ [123]. 75 and 76 are the first alkaline earth-metal-templated alumino-/gallo-borates. Their structures contain chiral $\left[\mathrm{AlO}_{4}\right] /\left[\mathrm{GaO}_{4}\right]$ groups connecting two types of oxoboron cluster units, three $\left[\mathrm{B}_{3} \mathrm{O}_{7}\right]$ and one $\left[\mathrm{B}_{4} \mathrm{O}_{9}\right]$, which collectively form 14-MR channels (Figure 27). SHG measurements indicate type I phasematchable behavior with an efficiency of $3.0 \times \mathrm{KDP}$, while 75 and 76 have absorption edges below 200 and $206 \mathrm{~nm}$, respectively. The structure of another important example, 74, features a 3D zeolite-like framework and consists of a $\left[\mathrm{B}_{9} \mathrm{O}_{19}\right]$ primary building unit with 6-membered-ring channels (Figure 28). SHG measurements show that $\mathbf{7 4}$ is type I phase-matchable with a SHG 
response of $1.2 \times \mathrm{KDP}$ at $1064 \mathrm{~nm}$ and $0.33 \times \mathrm{BBO}$ at $532 \mathrm{~nm}$, and a wide transparency range (absorption edge below $200 \mathrm{~nm}$ ).

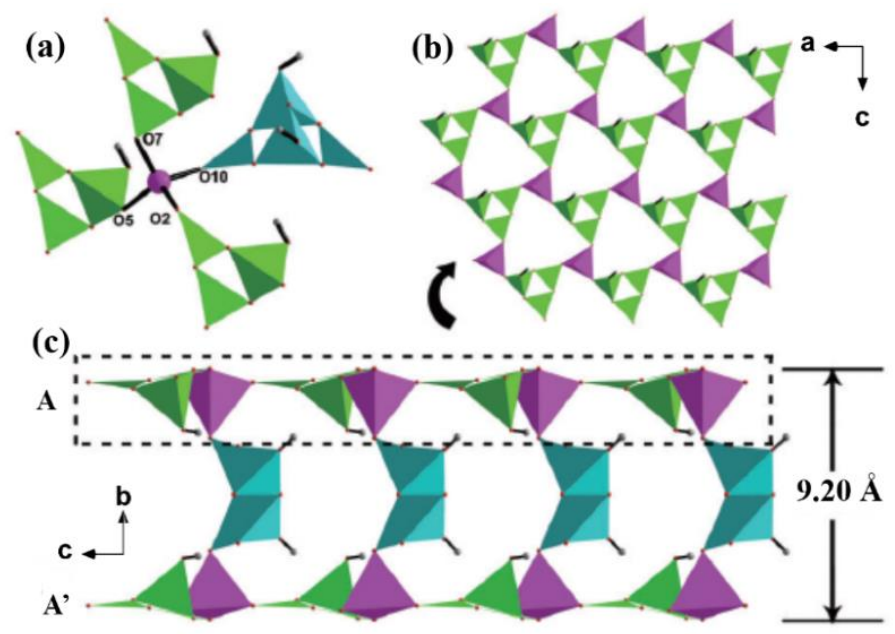

Figure 27. (a) View of the $\left[\mathrm{B}_{4} \mathrm{O}_{9}\right]$ and $\left[\mathrm{B}_{3} \mathrm{O}_{7}\right]$ cluster units in $\mathbf{7 5}$ and 76. (b) The connectivity between the $\left[\mathrm{B}_{3} \mathrm{O}_{7}\right]$ units and $\left[\mathrm{AlO}_{4}\right]$ groups. (c) View of the porous pillar-layered sandwich built up by the $\mathrm{ABO}$ layers and $\left[\mathrm{B}_{4} \mathrm{O}_{9}\right]$ cluster pillars, showing the linkages of the $\left[\mathrm{B}_{4} \mathrm{O}_{9}\right]$ pillars and $\left[\mathrm{AlO}_{4}\right]$ groups. (Color code: $\mathrm{AlO}_{4}$ pink, $\left[\mathrm{B}_{3} \mathrm{O}_{7}\right]$ green, [B $\left.\mathrm{B}_{4} \mathrm{O}_{9}\right]$ cyan) [126]. (C) 2013 WILEY-VCH.

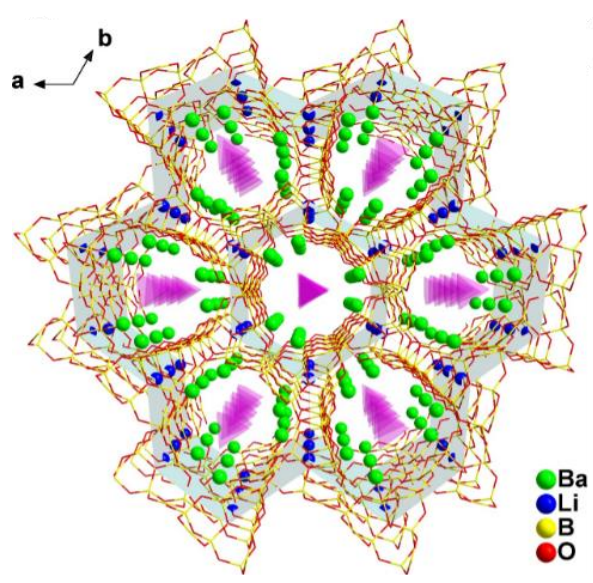

(a)

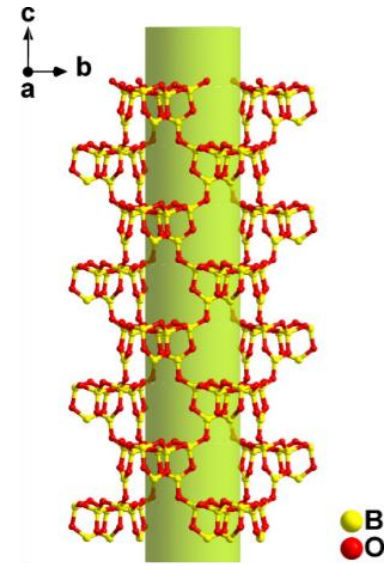

(b)

Figure 28. (a) Crystal structure of $\mathrm{LiBa}_{3}(\mathrm{OH})\left(\mathrm{B}_{9} \mathrm{O}_{16}\right)\left[\mathrm{B}(\mathrm{OH})_{4}\right]$ (74) with 6-membered-ring channels. (b) View of the 6-membered-ring channels in $\mathrm{LiBa}_{3}(\mathrm{OH})\left(\mathrm{B}_{9} \mathrm{O}_{16}\right)\left[\mathrm{B}(\mathrm{OH})_{4}\right]$ (74) [124]. () 2016 Royal Society of Chemistry.

Hydrothermal, solvothermal, surfactant-thermal and solution evaporation methods have been demonstrated to be facile routes for constructing hydrated metal borates. However, it is difficult 
to control the structural configuration of planar triangular $\left[\mathrm{BO}_{3}\right]$ and tetrahedral $\left[\mathrm{BO}_{4}\right]$ under solution conditions. The presence of $\mathrm{OH}^{-}$and/or $\mathrm{H}_{2} \mathrm{O}$ may result in poor chemical and/or thermal stabilities, and a red-shift in the UV absorption edge of the NLO crystals. Given the large number of NCS metal borates containing halides, it is expected that substitution of $\mathrm{OH}^{-}$with halides in this class of crystals should provide a new route to NLO-active crystals.

\subsection{Metal borates with mixed anions}

Metal borates with mixed anions (e.g., borate-phosphates (borate and phosphate groups isolated), borophosphates (borate and phosphate groups connected), borosilicates, and acetateborates) and for which NLO studies have been undertaken are collected in Table 4.

\section{Table 4}

NLO data for metal borates with mixed anions

\begin{tabular}{|c|c|c|c|c|c|}
\hline Compounds & $\begin{array}{l}\text { Space } \\
\text { group }\end{array}$ & Structural feature & Absorption Edge & $\begin{array}{l}\text { SHG intensity } \\
(@ 1064 \mathrm{~nm})\end{array}$ & Ref. \\
\hline $\mathrm{KSrBP}_{2} \mathrm{O}_{8}$ & $\overline{I \overline{4} 2 d}$ & {$\left[\mathrm{BP}_{2} \mathrm{O}_{8}\right]$} & $313 \mathrm{~nm}(3.97 \mathrm{eV})$ & $0.2 \times \mathrm{KDP}$ & {$[127]$} \\
\hline $\mathrm{KBaBP}_{2} \mathrm{O}_{8}$ & $I \overline{4} 2 d$ & {$\left[\mathrm{BP}_{2} \mathrm{O}_{8}\right]$} & N/A & $0.3 \times \mathrm{KDP}$ & [127] \\
\hline $\mathrm{KB}\left(\mathrm{PO}_{4}\right) \mathrm{F}$ & $C c$ & {$\left[\mathrm{BPO}_{4} \mathrm{~F}\right]$} & $<200 \mathrm{~nm}(>6.20 \mathrm{eV})$ & $1.21 \times \mathrm{KDP}$ & [128] \\
\hline $\mathrm{Ba}_{3}\left(\mathrm{ZnB}_{5} \mathrm{O}_{10}\right) \mathrm{PO}_{4}$ & $P m n 2_{1}$ & {$\left[\mathrm{ZnB}_{5} \mathrm{O}_{10}\right],\left[\mathrm{PO}_{4}\right]$} & $180 \mathrm{~nm}(6.89 \mathrm{eV})$ & $4.0 \times \mathrm{KDP}$ & {$[129,130]$} \\
\hline $\mathrm{Cs}_{2} \mathrm{~B}_{4} \mathrm{SiO}_{9}$ & $I \overline{4}$ & {$\left[\mathrm{~B}_{4} \mathrm{O}_{10}\right],\left[\mathrm{SiO}_{4}\right]$} & $<190 \mathrm{~nm}(>6.53 \mathrm{eV})$ & $4.6 \times \mathrm{KDP}$ & [131] \\
\hline $\mathrm{Ba}_{4}\left(\mathrm{BO}_{3}\right)_{3}\left(\mathrm{SiO}_{4}\right) \cdot \mathrm{Ba}_{3} \mathrm{Cl}$ & $P 6_{3} m c$ & {$\left[\mathrm{BO}_{3}\right],\left[\mathrm{SiO}_{4}\right]$} & $190 \mathrm{~nm}(6.53 \mathrm{eV})$ & $1.0 \times \mathrm{KDP}$ & [132] \\
\hline $\mathrm{Ba}_{4}\left(\mathrm{BO}_{3}\right)_{3}\left(\mathrm{SiO}_{4}\right) \cdot \mathrm{Ba}_{3} \mathrm{Br}$ & $P 6_{3} m c$ & {$\left[\mathrm{BO}_{3}\right],\left[\mathrm{SiO}_{4}\right]$} & $190 \mathrm{~nm}(6.53 \mathrm{eV})$ & $1.0 \times \mathrm{KDP}$ & [132] \\
\hline $\mathrm{La}_{2}\left(\mathrm{CH}_{3} \mathrm{CO}_{2}\right)_{2}\left[\mathrm{~B}_{5} \mathrm{O}_{9}(\mathrm{OH})\right] \cdot \mathrm{H}_{2} \mathrm{O}$ & $C c$ & {$\left[\mathrm{~B}_{5} \mathrm{O}_{12}\right],\left[\mathrm{CH}_{3} \mathrm{CO}_{2}\right]$} & $230 \mathrm{~nm}(5.38 \mathrm{eV})^{a}$ & $2.0 \times \mathrm{KDP}$ & [133] \\
\hline $\mathrm{Ce}_{2}\left(\mathrm{CH}_{3} \mathrm{CO}_{2}\right)_{2}\left[\mathrm{~B}_{5} \mathrm{O}_{9}(\mathrm{OH})\right] \cdot \mathrm{H}_{2} \mathrm{O}$ & $C c$ & {$\left[\mathrm{~B}_{5} \mathrm{O}_{12}\right],\left[\mathrm{CH}_{3} \mathrm{CO}_{2}\right]$} & $308 \mathrm{~nm}(4.02 \mathrm{eV})^{a}$ & $1.0 \times \mathrm{KDP}$ & [133] \\
\hline $\mathrm{Pr}_{2}\left(\mathrm{CH}_{3} \mathrm{CO}_{2}\right)_{2}\left[\mathrm{~B}_{5} \mathrm{O}_{9}(\mathrm{OH})\right] \cdot \mathrm{H}_{2} \mathrm{O}$ & $C c$ & {$\left[\mathrm{~B}_{5} \mathrm{O}_{12}\right],\left[\mathrm{CH}_{3} \mathrm{CO}_{2}\right]$} & $231 \mathrm{~nm}(5.36 \mathrm{eV})^{a}$ & $1.4 \times \mathrm{KDP}$ & [133] \\
\hline $\mathrm{La}_{2}\left(\mathrm{CH}_{3} \mathrm{CO}_{2}\right)_{2}\left[\mathrm{~B}_{5} \mathrm{O}_{9}(\mathrm{OH})\right]$ & $C c$ & {$\left[\mathrm{~B}_{5} \mathrm{O}_{12}\right],\left[\mathrm{CH}_{3} \mathrm{CO}_{2}\right]$} & $241 \mathrm{~nm}(5.14 \mathrm{eV})^{a}$ & $2.5 \times \mathrm{KDP}$ & [133] \\
\hline
\end{tabular}

${ }^{a}$ Energy bandgap.

The isostructural $\mathrm{KMBP}_{2} \mathrm{O}_{8}(\mathrm{M}=\mathrm{Sr}(\mathbf{7 8}), \mathrm{Ba}(\mathbf{7 9}) ; \overline{4} 2 d)$, obtained by the high-temperature solution method, have structures featuring a 3D diamond framework composed of $\left[\mathrm{BO}_{4}\right]$ and $\left[\mathrm{PO}_{4}\right]$ tetrahedra [127]. SHG measurements indicate that they are phase-matchable with SHG efficiencies 
ca. $0.2 \times \mathrm{KDP}(\mathbf{7 8})$ and $0.3 \times \mathrm{KDP}(\mathbf{7 9})$ and absorption edges around $313 \mathrm{~nm}(3.97 \mathrm{eV})$. The alkalimetal fluorinated borophosphate $\mathrm{KB}\left(\mathrm{PO}_{4}\right) \mathrm{F} 80(C c)$ was synthesized via fluoro-hydrothermal methods $[128]$; it exhibits a $2 \mathrm{D}\left[\mathrm{BPO}_{4} \mathrm{~F}\right]_{\infty}$ layer structure assembled from $\left[\mathrm{BO}_{3} \mathrm{~F}\right]$ and $\left[\mathrm{PO}_{4}\right]$ tetrahedral groups, its absorption edge is less than $200 \mathrm{~nm}$, and its SHG response is similar to that of KDP.

Large crystals of the borate-phosphate $\mathrm{Ba}_{3}\left(\mathrm{ZnB}_{5} \mathrm{O}_{10}\right) \mathrm{PO}_{4}(\mathbf{8 1})\left(\right.$ dimensions $31 \times 23 \times 7 \mathrm{~mm}^{3}$ ) were grown by the TSSG method $[129,130]$. The basic building unit of $\mathbf{8 1}$ is the $\left[\mathrm{ZnB}_{5} \mathrm{O}_{10}\right]$ group which is composed of three $\left[\mathrm{BO}_{3}\right]$ triangles, two $\left[\mathrm{BO}_{4}\right]$ tetrahedra and one $\left[\mathrm{ZnO}_{4}\right]$ tetrahedron. Adjacent $\left[\mathrm{ZnB}_{5} \mathrm{O}_{10}\right]$ building units share corners through oxygen atoms to create a $\left[\mathrm{ZnB}_{5} \mathrm{O}_{10}\right]_{\infty}$ framework. $\mathrm{Ba}$ atoms and the isolated $\left[\mathrm{PO}_{4}\right]$ tetrahedra fill the voids in the $\left[\mathrm{ZnB}_{5} \mathrm{O}_{10}\right]_{\infty}$ framework (Figure 29). Crystal 81 possesses an absorption edge of $180 \mathrm{~nm}$ and large SHG efficiencies of approximately $4 \times \mathrm{KDP}$ and $0.5 \times \beta$-BBO at 532 and $266 \mathrm{~nm}$, respectively, and exhibits type I phase-matchable behavior at both wavelengths. Refractive index measurements indicate that $\mathbf{8 1}$ is a negative biaxial crystal with birefringence ranging from 0.0418 to 0.0306 in a wavelength range of $253.6-2325.4 \mathrm{~nm}[130]$.

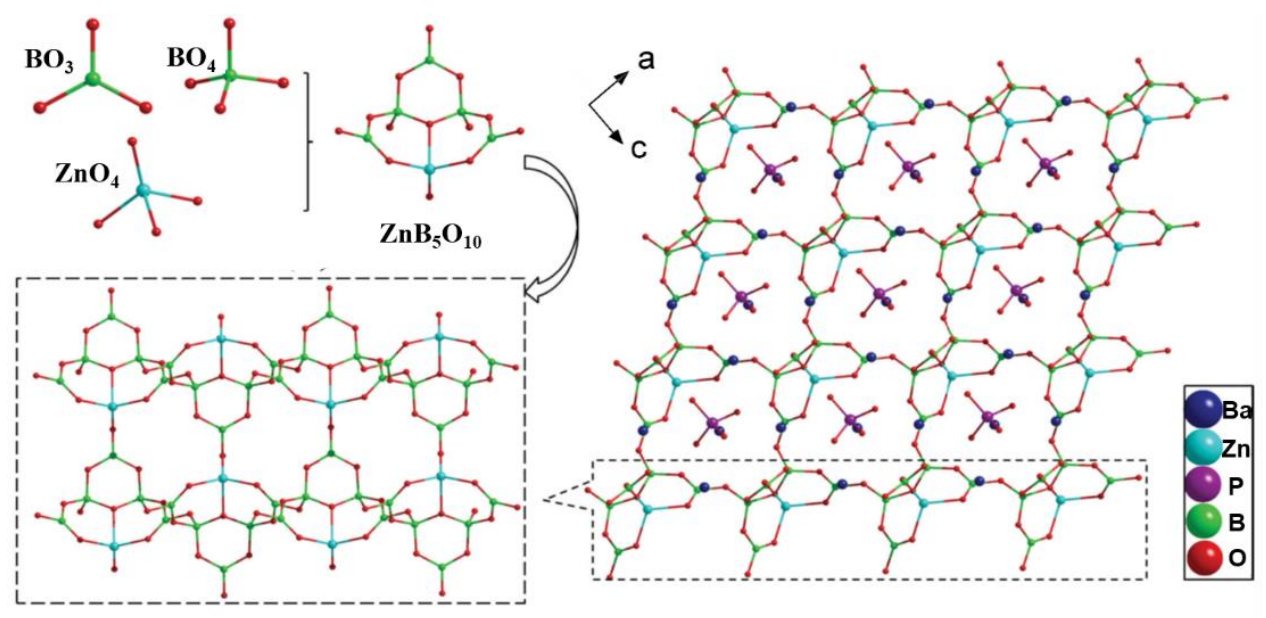

Figure 29. Crystal structure of $\mathrm{Ba}_{3}\left(\mathrm{ZnB}_{5} \mathrm{O}_{10}\right) \mathrm{PO}_{4}$ (81) [129]. () 2015 WILEY-VCH. 


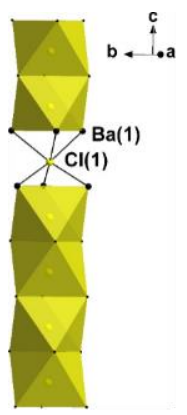

(a) ${ }_{\infty}^{1}\left[\mathrm{Ba}_{3} \mathrm{Cl}\right]$

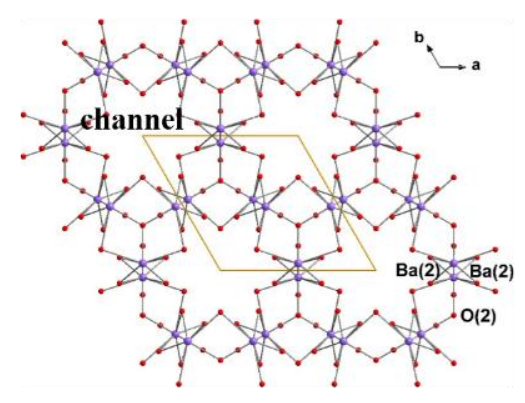

(b) Ba-based 3D framework

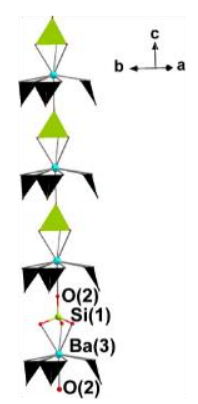

(c) ${ }_{\infty}^{1}\left[\mathrm{Ba}\left(\mathrm{BO}_{3}\right)_{3}\left(\mathrm{SiO}_{4}\right)\right]$

\section{$\downarrow$}

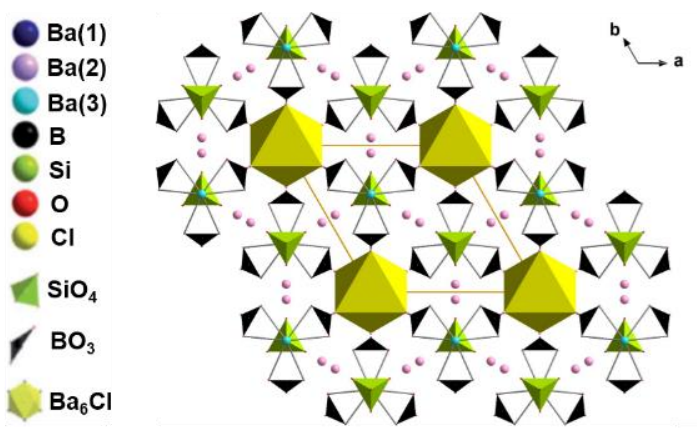

(d) 3D network of $\mathrm{Ba}_{4}\left(\mathrm{BO}_{3}\right)_{3}\left(\mathrm{SiO}_{4}\right) \cdot \mathrm{Ba}_{3} \mathrm{Cl}$

Figure 30. Crystal structure of $\mathrm{Ba}_{4}\left(\mathrm{BO}_{3}\right)_{3}\left(\mathrm{SiO}_{4}\right) \cdot \mathrm{Ba} 3 \mathrm{Cl}(\mathbf{8 3})$ [132]. (C) 2014 Royal Society of Chemistry.

The borosilicate $\mathrm{Cs}_{2} \mathrm{~B}_{4} \mathrm{SiO}_{9}(\mathbf{8 2})$ was synthesized from a high-temperature solution using $\mathrm{Cs}_{2} \mathrm{CO}_{3}$ as the flux [131]. 82 crystallizes in the space group $I \overline{4}$ with its structure consisting of $\left[\mathrm{B}_{4} \mathrm{O}_{10}\right]$ and $\left[\mathrm{SiO}_{4}\right]$ tetrahedra. The $\left[\mathrm{B}_{4} \mathrm{O}_{10}\right]$ groups are connected with neighboring $\left[\mathrm{SiO}_{4}\right]$ tetrahedra to form a 3D network with tunnels along the $b$-axis in which the $\mathrm{Cs}^{+}$atoms reside. The UV absorption edge is lower than $190 \mathrm{~nm} .82$ exhibits a SHG response 4.6 times larger than KDP, its SHG behavior mainly originating from the distorted $\left[\mathrm{BO}_{4}\right]$ units and $\left[\mathrm{Cs}_{2} \mathrm{O}_{12}\right]$ polyhedra. Two further isostructural borosilicates $\mathrm{Ba}_{4}\left(\mathrm{BO}_{3}\right)_{3}\left(\mathrm{SiO}_{4}\right) \cdot \mathrm{Ba}_{3} \mathrm{X}\left(\mathrm{X}=\mathrm{Cl}(\mathbf{8 3})\right.$ (Figure 30), $\left.\mathrm{Br}(\mathbf{8 4}) ; P 6_{3} m c\right)$ were synthesized from high-temperature solutions using $\mathrm{Na}_{2} \mathrm{O}-\mathrm{H}_{3} \mathrm{BO}_{3}$ and $\mathrm{NaBr}-\mathrm{H}_{3} \mathrm{BO}_{3}$ as the flux, respectively [132]. Their structures feature a $\left[\mathrm{Ba}_{4}\left(\mathrm{BO}_{3}\right)_{3}\left(\mathrm{SiO}_{4}\right)\right]_{\infty}$ framework with 1D channels along the $c$-axis in which the polar $\left[\mathrm{Ba}_{3} \mathrm{X}\right]_{\infty}$ chains reside. SHG measurements show that both 83 and 84 have SHG responses similar to that of KDP and are type I phase-matchable. In 
addition, they melt congruently and exhibit wide transparency ranges with UV absorption edges below $190 \mathrm{~nm}$.

The lanthanide acetate-borates $\mathrm{Ln}_{2}\left(\mathrm{CH}_{3} \mathrm{CO}_{2}\right)_{2}\left[\mathrm{~B}_{5} \mathrm{O}_{9}(\mathrm{OH})\right] \cdot \mathrm{H}_{2} \mathrm{O}(\mathrm{Ln}=\mathrm{La}(\mathbf{8 5}), \mathrm{Ce}(\mathbf{8 6}), \mathrm{Pr}$ (87); Cc) were synthesized under hydrothermal conditions [133]. These compounds are isostructural and feature $\operatorname{Ln}\left[\mathrm{B}_{5} \mathrm{O}_{9}(\mathrm{OH})\right] 2 \mathrm{D}$ layers which are bridged by lanthanide ions to form a $3 \mathrm{D}$ network. Crystals 85-87 can be transformed into $\mathrm{Ln}_{2}\left(\mathrm{CH}_{3} \mathrm{CO}_{2}\right)_{2}\left[\mathrm{~B}_{5} \mathrm{O}_{9}(\mathrm{OH})\right](\mathrm{Ln}=\mathrm{La}(\mathbf{8 8}), \mathrm{Ce}$ (89), $\operatorname{Pr}(\mathbf{9 0})$; $C c)$ by heating at $500 \mathrm{~K}[133] . \mathbf{8 5 - 8 7}$ and the La derivative $\mathbf{8 8}$ are wide bandgap semiconductors displaying energy bandgaps of $5.38,4.02,5.36$, and $5.14 \mathrm{eV}$, respectively. In addition, 85-87 and $\mathbf{8 8}$ are phase-matchable and display SHG signals of ca. 2.0, 1.0, 1.4, and 2.5 times that of KDP, respectively. DFT studies suggest that the relatively large SHG efficiencies of these compounds originate from a synergistic effect between the $\pi$-conjugated $\left[\mathrm{BO}_{3}\right]$ units and the $\left[\mathrm{CH}_{3} \mathrm{COO}\right]$ units (Figure 31 ).

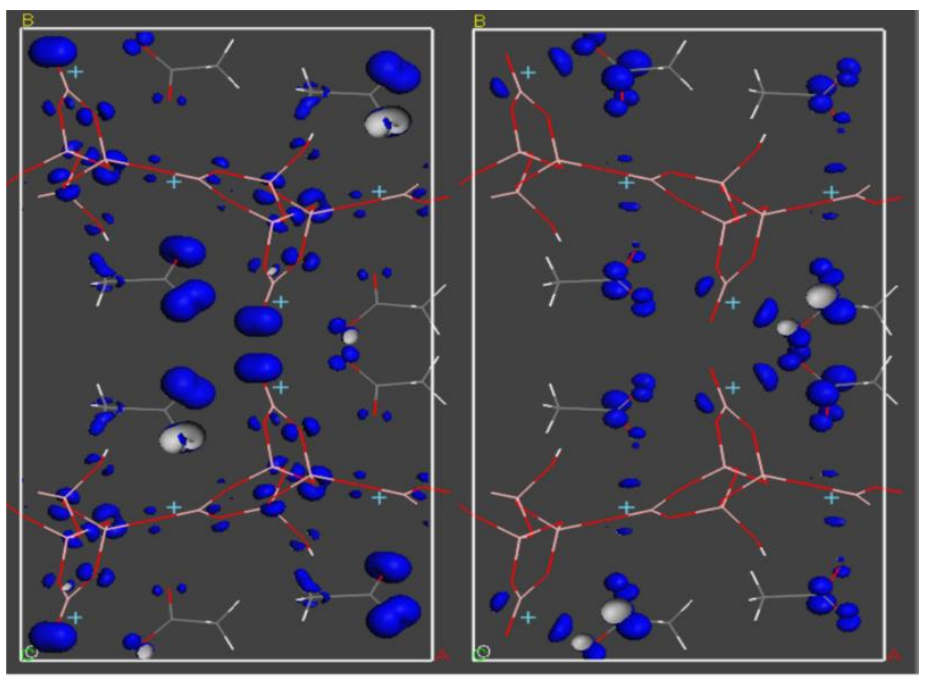

(a)

(b)

Figure 31. SHG density of $d_{11}$ in VB and CB for 88 [133]. (c) 2015 American Chemical Society.

Metal borates with mixed anions represent an interesting class of UV and deep-UV NLO crystals owing to their improved transparency/optical nonlinearity trade-off. The second type of 
anionic units has significant influences on both crystal structures and NLO properties of these mixed-anion metal borates. Therefore, the combination of two or even three different anions in one crystal structure may offer new prospects for UV and deep-UV NLO materials.

\section{Metal carbonates}

Carbonates are another group of important NLO material for the UV and deep-UV regions. Analogous to the $\left[\mathrm{BO}_{3}\right]$ group, the $\left[\mathrm{CO}_{3}\right]$ group is expected to be a good NLO microstructural unit since it possesses a similar planar triangular structure with $\pi$-conjugated molecular orbitals which can produce large second-order susceptibility. In the past 10 years, a number of carbonates have been found to be SHG-active (Tables 5-6). The crystal structures of these compounds all consist of isolated $\left[\mathrm{CO}_{3}\right]$ groups. Carbonates can be classified into two subgroups which will be discussed in the following sections.

\subsection{Metal carbonates without additional anionic groups}

$\mathrm{CsNa}_{5} \mathrm{Ca}_{5}\left(\mathrm{CO}_{3}\right)_{8}\left(\right.$ 91) $\left(\mathrm{P}_{3} \mathrm{mc}\right)$ was obtained by hydrothermal methods from a mixture of $\mathrm{Na}_{2} \mathrm{CO}_{3}, \mathrm{CsCl}, \mathrm{CaCl}_{2}$, and $\mathrm{H}_{2} \mathrm{O}$ [134]. The structure of 91 can be described as "standing-on-edge" $\left[\mathrm{CO}_{3}\right]$ groups connecting adjacent infinite $\left[\mathrm{CaCO}_{3}\right]_{\infty}$ layers in the $a b$ plane to construct a framework with four types of channels running parallel to [010] plane (Figure 32). The absorption edge of the material is $210 \mathrm{~nm}(5.92 \mathrm{eV})$, while SHG measurements revealed its type I phasematchable behavior with an efficiency of $3.0 \times \mathrm{KDP}$.

\section{Table 5}

The NLO data of metal carbonates without additional anionic groups.

\begin{tabular}{llllll}
\hline Compounds & Space group & Structure feature & Bandgap & $\begin{array}{l}\text { SHG intensity } \\
(@ 1064 \mathrm{~nm})\end{array}$ & Ref. \\
\hline $\mathrm{CsNa}_{5} \mathrm{Ca}_{5}\left(\mathrm{CO}_{3}\right)_{8}$ & $P 6_{3} m c$ & & $210 \mathrm{~nm}(5.92 \mathrm{eV})$ & $1.0 \times \mathrm{KDP}$ & {$[134]$} \\
$\mathrm{Na}_{4} \mathrm{La}_{2}\left(\mathrm{CO}_{3}\right)_{5}$ & $P 6_{3} m c$ & & $235 \mathrm{~nm}(5.29 \mathrm{eV})$ & $3.0 \times \mathrm{KDP}$ & {$[134]$}
\end{tabular}




$\begin{array}{llll}\mathrm{Na}_{3} \mathrm{Y}\left(\mathrm{CO}_{3}\right) & \mathrm{Ama} 2 & 222 \mathrm{~nm}(5.59 \mathrm{eV}) & 3.57 \times \mathrm{KDP} \\ \mathrm{Na}_{3} \mathrm{Gd}\left(\mathrm{CO}_{3}\right) & \mathrm{Ama2} & 223 \mathrm{~nm}(5.57 \mathrm{eV}) & 3.54 \times \mathrm{KDP}\end{array}$

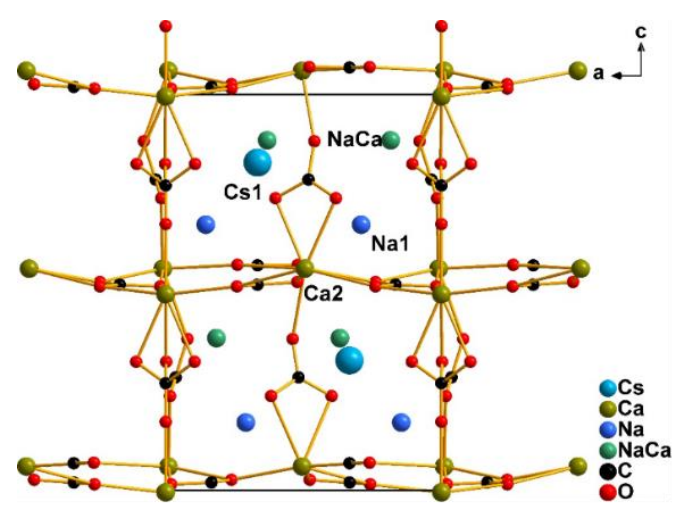

(a)

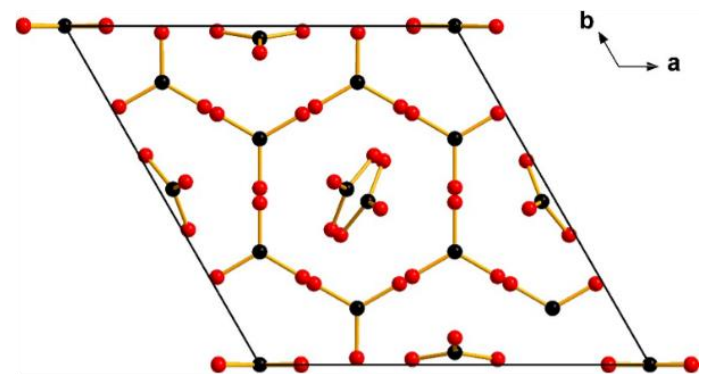

(b)

Figure 32. (a) Crystal structure of $\mathrm{CsNa}_{5} \mathrm{Ca}_{5}\left(\mathrm{CO}_{3}\right)_{8}$ (91). (b) The "lying-flat" and "standing-on-edge" $\left[\mathrm{CO}_{3}\right]$ groups in $\mathrm{CsNa}_{5} \mathrm{Ca}_{5}\left(\mathrm{CO}_{3}\right)_{8}$ (91) [134]. (C) 2014 American Chemical Society.

The NLO properties of three further rare-earth-based carbonates $\left(\mathrm{Na}_{4} \mathrm{La}_{2}\left(\mathrm{CO}_{3}\right)_{5}(\mathbf{9 2})\left(P 6_{3} m c\right)\right.$ [134], $\mathrm{Na}_{3} \mathrm{Y}\left(\mathrm{CO}_{3}\right)(\mathbf{9 3})$ (Ama2) [135], and $\mathrm{Na}_{3} \mathrm{Gd}\left(\mathrm{CO}_{3}\right)$ (94) (Ama2) [135]) have been reported, all three being obtained by hydrothermal methods. The structure of 92 exhibits a 3D network made up of $\left[\mathrm{CO}_{3}\right]$ triangles as well as irregular $\left[\mathrm{Na}_{0.67} \mathrm{La}_{0.33} \mathrm{O}_{10}\right]$ and $\left[\mathrm{NaO}_{8}\right]$ polyhedra, while isostructural 93 and 94 possess structures with alternating stacking of $\left[\mathrm{Na}\left(\mathrm{CO}_{3}\right)_{2}\right]_{\infty}$ and $\left[\mathrm{Na}_{2} \mathrm{RE}\left(\mathrm{CO}_{3}\right)_{2}\right]_{\infty}$. All three compounds exhibit absorption edges near the deep-UV region. SHG measurements revealed their type I phase-matchable behavior, with efficiencies ranging from 3.0 $\times \mathrm{KDP}(\mathbf{9 2})$ to $3.57 \times \mathrm{KDP}(\mathbf{9 3})$ and $3.54 \times \mathrm{KDP}(\mathbf{9 4})$. The large structural criterion $C$ and high density of the $\left[\mathrm{CO}_{3}\right]$ groups play a key role in their large macroscopic SHG coefficients.

\subsection{Metal carbonate fluorides}

Metal carbonate fluorides are another important class of NLO materials active in the UV and deep-UV regions (Table 6). The addition of fluoride not only serves to blue-shift the absorption 
edge, but also leads to large distortions or polarizations of local structural units, significantly affecting the structural types and NLO properties of the materials.

\section{Table 6}

NLO data for metal carbonate fluorides.

\begin{tabular}{|c|c|c|c|c|c|}
\hline Compounds & Space group & $\begin{array}{l}\text { Structural } \\
\text { feature }\end{array}$ & Absorption edge & $\begin{array}{l}\text { SHG intensity } \\
\text { (@ } 1064 \mathrm{~nm})\end{array}$ & Ref. \\
\hline $\mathrm{KSrCO}_{3} \mathrm{~F}$ & $P \overline{6} 2 m$ & & $<200 \mathrm{~nm}(>6.2 \mathrm{eV})$ & $3.33 \times \mathrm{KDP}$ & {$[136]$} \\
\hline $\mathrm{RbSrCO}_{3} \mathrm{~F}$ & $P \overline{6} 2 m$ & & $<200 \mathrm{~nm}(>6.2 \mathrm{eV})$ & $3.33 \times \mathrm{KDP}$ & {$[136]$} \\
\hline $\mathrm{KCaCO}_{3} \mathrm{~F}$ & $P \overline{6} 2 m$ & & $<200 \mathrm{~nm}(>6.2 \mathrm{eV})$ & $3.61 \times \mathrm{KDP}$ & {$[136]$} \\
\hline $\mathrm{RbCaCO}_{3} \mathrm{~F}$ & $P \overline{6} 2 m$ & & $<200 \mathrm{~nm}(>6.2 \mathrm{eV})$ & $1.11 \times \mathrm{KDP}$ & {$[136]$} \\
\hline $\mathrm{CsCaCO}_{3} \mathrm{~F}$ & $P \overline{6} 2 m$ & & $<200 \mathrm{~nm}(>6.2 \mathrm{eV})$ & $1.11 \times \mathrm{KDP}$ & [136] \\
\hline $\mathrm{RbMgCO}_{3} \mathrm{~F}$ & $P \overline{6} 2 m$ & & $<190 \mathrm{~nm}(>6.53 \mathrm{eV})$ & $4.0 \times \mathrm{KDP}$ & {$[137]$} \\
\hline $\mathrm{KMgCO}_{3} \mathrm{~F}$ & $P \overline{6} 2 m$ & & $<200 \mathrm{~nm}(>6.2 \mathrm{eV})$ & $3.0 \times \mathrm{KDP}$ & {$[138]$} \\
\hline $\mathrm{Na}_{8} \mathrm{Lu}_{2}\left(\mathrm{CO}_{3}\right)_{6} \mathrm{~F}_{2}$ & $C c$ & & $<200 \mathrm{~nm}(>6.2 \mathrm{eV})$ & $4.29 \times \mathrm{KDP}$ & {$[140]$} \\
\hline $\mathrm{Na}_{3} \mathrm{Lu}\left(\mathrm{CO}_{3}\right)_{2} \mathrm{~F}_{2}$ & $C c$ & & $<200 \mathrm{~nm}(>6.2 \mathrm{eV})$ & $4.21 \times \mathrm{KDP}$ & {$[140]$} \\
\hline $\mathrm{Ca}_{2} \mathrm{Na}_{3}\left(\mathrm{CO}_{3}\right)_{3} \mathrm{~F}$ & $\mathrm{Cm}$ & {$\left[\mathrm{CO}_{3}\right]$} & $190 \mathrm{~nm}(6.52 \mathrm{eV})$ & $3.0 \times \mathrm{KDP}$ & [139] \\
\hline $\mathrm{Cs}_{3} \mathrm{Ba}_{4}\left(\mathrm{CO}_{3}\right)_{3} \mathrm{~F}_{5}$ & $P 6_{3} m c$ & & $210 \mathrm{~nm}(5.90 \mathrm{eV})^{a}$ & $1.20 \times \mathrm{KDP}$ & {$[136]$} \\
\hline $\mathrm{Cs}_{9} \mathrm{Mg}_{6}\left(\mathrm{CO}_{3}\right)_{8} \mathrm{~F}_{5}$ & $P m n 2_{1}$ & & $208 \mathrm{~nm}(5.96 \mathrm{eV})$ & $0.5 \times \mathrm{KDP}$ & {$[138]$} \\
\hline \multirow[t]{2}{*}{$\mathrm{KCdCO}_{3} \mathrm{~F}$} & $P \overline{6} c 2$ & & $235 \mathrm{~nm}(5.30 \mathrm{eV})^{a}$ & $4.58 \times \mathrm{KDP}$ & {$[141,142$,} \\
\hline & & & & & 143] \\
\hline $\mathrm{RbCdCO}_{3} \mathrm{~F}$ & $P \overline{6} c 2$ & & $233 \mathrm{~nm}(5.35 \mathrm{eV})^{a}$ & $2.8 \times \mathrm{KDP}$ & {$[141,143]$} \\
\hline $\mathrm{KZnCO}_{3} \mathrm{~F}$ & $P \overline{6} c 2$ & & $390 \mathrm{~nm}(3.17 \mathrm{eV})^{a}$ & $1.76 \times \mathrm{KDP}$ & {$[141]$} \\
\hline $\mathrm{RbZnCO}_{3} \mathrm{~F}$ & $P \overline{6} c 2$ & & $384 \mathrm{~nm}(3.23 \mathrm{eV})^{a}$ & $0.83 \times \mathrm{KDP}$ & {$[141]$} \\
\hline $\mathrm{K}_{2.7} \mathrm{~Pb}_{5.15}\left(\mathrm{CO}_{3}\right)_{5} \mathrm{~F}_{3}$ & $P \overline{6} m 2$ & & $326 \mathrm{~nm}(3.8 \mathrm{eV})^{a}$ & $1.0 \times \mathrm{KDP}$ & [146] \\
\hline $\mathrm{CsPbCO}_{3} \mathrm{~F}$ & $P \overline{6} 2 m$ & & $300 \mathrm{~nm}(4.15 \mathrm{eV})^{a}$ & $7.5(13.4) \times \mathrm{KDP}$ & {$[144,145]$} \\
\hline $\mathrm{RbPbCO}_{3} \mathrm{~F}$ & $P \overline{6} 2 m$ & & $302 \mathrm{~nm}(4.1 \mathrm{eV})^{a}$ & $6.25 \times \mathrm{KDP}$ & {$[144]$} \\
\hline
\end{tabular}

${ }^{a}$ Energy bandgap.

The compounds $\mathrm{ABCO}_{3} \mathrm{~F}\left(\mathrm{~A}^{+}=\right.$alkali metal; $\mathrm{B}^{2+}=$ alkaline earth metal $)$ comprise one family of NCS carbonate fluorides that are promising deep-UV NLO materials. These include $\mathrm{KSrCO}_{3} \mathrm{~F}$ (95), $\mathrm{RbSrCO}_{3} \mathrm{~F}$ (96), $\mathrm{KCaCO}_{3} \mathrm{~F}\left(\right.$ 97), $\mathrm{RbCaCO}_{3} \mathrm{~F}$ (98), $\mathrm{CsCaCO}_{3} \mathrm{~F}$ (99), $\mathrm{KMgCO}_{3} \mathrm{~F}$ (100) and $\mathrm{RbMgCO}_{3} \mathrm{~F}$ (101) with $P \overline{6} 2 m$ space group, which were obtained through high-temperature 
solution and/or hydrothermal syntheses [136-138]. $\mathrm{ASrCO}_{3} \mathrm{~F}(\mathrm{~A}=\mathrm{K}(\mathbf{9 5}), \mathrm{Rb}(\mathbf{9 6})), 97$ and $\mathrm{ACaCO}_{3} \mathrm{~F}\left(\mathrm{~A}=\mathrm{Rb}\right.$ 98, $\mathrm{Cs}$ 99) are isostructural, with alternating stacking of $[\mathrm{AF}]_{\infty}(\mathrm{A}=\mathrm{K}, \mathrm{Rb}, \mathrm{Cs})$ and $\left[\mathrm{B}\left(\mathrm{CO}_{3}\right)\right]_{\infty}(\mathrm{B}=\mathrm{Ca}, \mathrm{Sr})$ layers as well as coplanar alignment of the $\left[\mathrm{CO}_{3}\right]$ triangles (Figure 33).

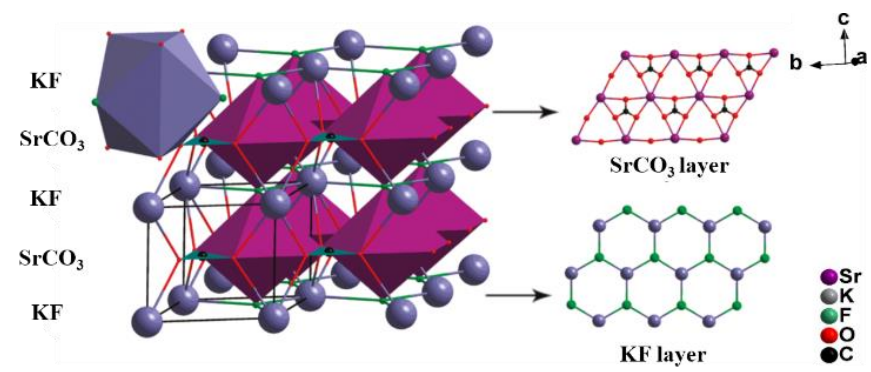

(a)

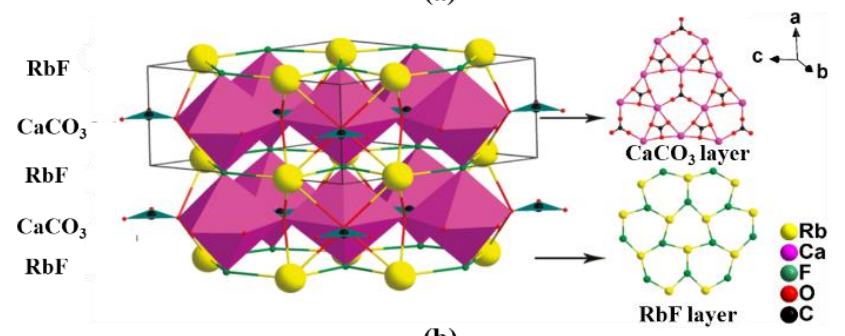

(b)

Figure 33. Crystal structures of (a) $\mathrm{KSrCO}_{3} \mathrm{~F}$ (95) and (b) $\mathrm{RbCaCO}_{3} \mathrm{~F}$ (98) [136]. (c) 2011 American Chemical Society.

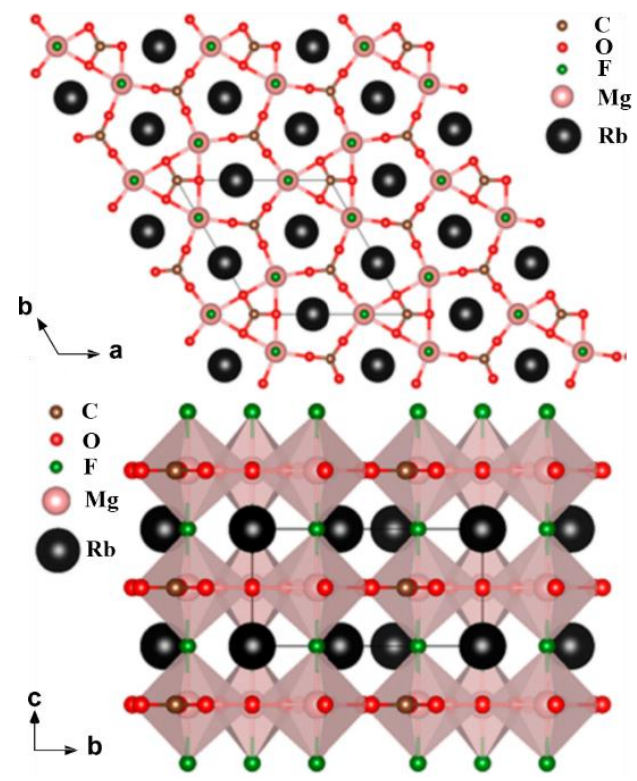

Figure 34. Crystal structure of $\mathrm{RbMgCO}_{3} \mathrm{~F}$ (101) [137]. (c) 2015 American Chemical Society. 
Interestingly, when $\mathrm{Ca}^{2+}$ or $\mathrm{Sr}^{2+}$ are replaced by $\mathrm{Mg}^{2+}$ (in proceeding to $\mathbf{1 0 0}$ and $\mathbf{1 0 1}$ ), a 3D structure consisting of corner-shared $\mathrm{Mg}\left(\mathrm{CO}_{3}\right)_{3} \mathrm{~F}_{2}$ polyhedra is seen. The inclusion of $\mathrm{Mg}^{2+}$ creates pentagonal channels in which the $\mathrm{K}^{+} / \mathrm{Rb}^{+}$ions reside (Figure 34). All seven materials exhibit an absorption edge in the deep-UV region. The measured SHG coefficients of 95-101 are ca. 3.33, $3.33,3.61,1.11,1.11,4.0$ and 3.0 times as large as that of KDP, respectively. Theoretical calculations support the conclusion that the coordination behavior of the counter-cations influences the denticity and alignment of the $\left[\mathrm{CO}_{3}\right]$ groups (Figure 35), and thereby leads to differences in the SHG responses. A further alkali metal-alkaline earth metal carbonate fluoride $\mathrm{Ca}_{2} \mathrm{Na}_{3}\left(\mathrm{CO}_{3}\right)_{3} \mathrm{~F}$ (102) $(\mathrm{Cm})$ has been reported [139]. A crystal grown from a high-temperature solution by using $\mathrm{LiF}$ as a flux revealed a framework structure that preserves the structural merits of $\mathrm{YCa}_{4} \mathrm{O}\left(\mathrm{BO}_{3}\right)_{3}$ (YCOB) (103). 102 possesses an absorption edge of $190 \mathrm{~nm}(6.52 \mathrm{eV})$, a SHG efficiency of $3.0 \times$ KDP, and birefringence of 0.082 . The substitution of SHG-active $\left[\mathrm{BO}_{3}\right]$ groups for $\left[\mathrm{CO}_{3}\right]$ groups in NLO borate crystals is a promising route to the improvement of NLO performance.

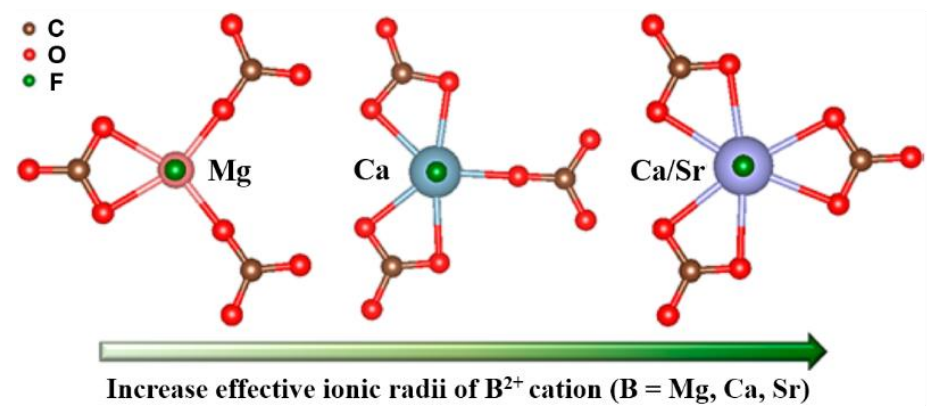

Figure 35. Different coordination denticities for $\mathrm{B}^{2+}$ cations $(\mathrm{B}=\mathrm{Mg}, \mathrm{Ca}, \mathrm{Sr})$ in $\mathrm{ABCO}_{3} \mathrm{~F}$ materials $(\mathrm{A}=\mathrm{K}, \mathrm{Rb}$, Cs) [137]. (c) 2011 American Chemical Society.

The rare-earth metal-containing compounds $\mathrm{Na}_{8} \mathrm{Lu}_{2}\left(\mathrm{CO}_{3}\right)_{6} \mathrm{~F}_{2}(\mathbf{1 0 4})$ and $\mathrm{Na}_{3} \mathrm{Lu}\left(\mathrm{CO}_{3}\right)_{2} \mathrm{~F}_{2}(\mathbf{1 0 5})$ in space group $C c$ were synthesized by hydrothermal reactions from a mixture of $\mathrm{Na}_{2} \mathrm{CO}_{3}, \mathrm{NaF}$, $\mathrm{Lu}\left(\mathrm{NO}_{3}\right)_{3} \cdot 6 \mathrm{H}_{2} \mathrm{O}$, and $\mathrm{H}_{2} \mathrm{O}$ in different molar ratios [140]. The structure of $\mathbf{1 0 4}$ features 1D $\left[\mathrm{Na}_{5} \mathrm{Lu}\left(\mathrm{CO}_{3}\right)_{2} \mathrm{~F}_{2}\right]$ chains connected by $\left[\mathrm{CO}_{3}\right]$ triangles, forming an intricate 3D framework (Figure 
36a). The structure of $\mathbf{1 0 5}$ is built from $\mathrm{NaLu}\left(\mathrm{CO}_{3}\right)_{2} \mathrm{~F}_{2}$ layers that extend to form a $3 \mathrm{D}$ framework by linkages with $\mathrm{Na}^{+}$cations (Figure 36b). 104 and $\mathbf{1 0 5}$ have powder SHG efficiencies of $4.29 \times$ KDP and 4.21× KDP, respectively, with absorption edges below $200 \mathrm{~nm} ; 104$ possesses the strongest SHG efficiency of all deep-UV carbonates.

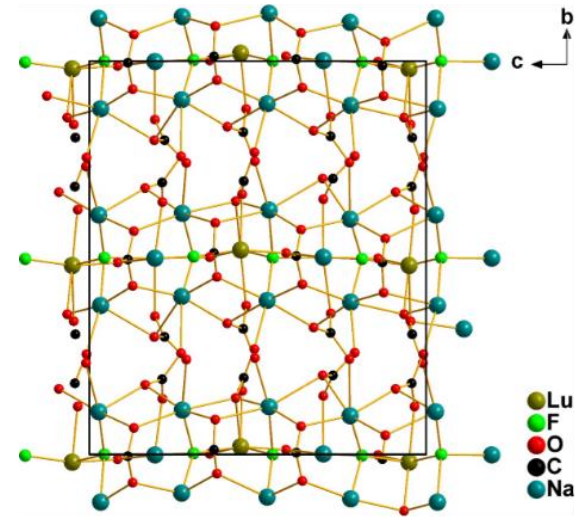

(a)

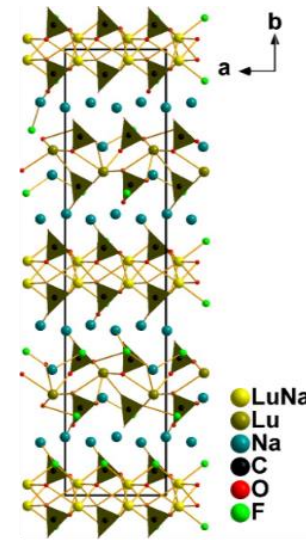

(b)

Figure 36. Crystal structures of (a) $\mathrm{Na}_{8} \mathrm{Lu}_{2}\left(\mathrm{CO}_{3}\right)_{6} \mathrm{~F}_{2}(\mathbf{1 0 4})$ and (b) $\mathrm{Na}_{3} \mathrm{Lu}\left(\mathrm{CO}_{3}\right)_{2} \mathrm{~F}_{2}$ (105) [140]. (C) 2013 American Chemical Society.

Crystals of compounds $\mathrm{Cs}_{3} \mathrm{Ba}_{4}\left(\mathrm{CO}_{3}\right)_{3} \mathrm{~F}_{5}(\mathbf{1 0 6})$ [136] and $\mathrm{Cs}_{9} \mathrm{Mg}_{6}\left(\mathrm{CO}_{3}\right)_{8} \mathrm{~F}_{5}$ (107) [138] were grown from high-temperature solution and solvothermal techniques, respectively, crystallizing in the hexagonal $P 6_{3} m c$ (106) and orthorhombic $P m n 2_{1}(\mathbf{1 0 7})$ space groups. 106 exhibits an intricate 3D framework of interconnecting $\mathrm{Ba}-$ centered polyhedra, $\mathrm{Cs}-$ centered polyhedra, and isolated $\left[\mathrm{CO}_{3}\right]$ triangles, whereas 107 has $3 \mathrm{D}$ structures constructed from corner-shared $\mathrm{Mg}-\mathrm{O} / \mathrm{F}$ and $\mathrm{Mg}-\mathrm{O}$ octahedra. The absorption edges for 106 and 107 are $210 \mathrm{~nm}$ and $208 \mathrm{~nm}$, respectively. SHG measurements reveal their type I phase-matchable behavior and efficiencies of 1.2 and $0.5 \times$ KDP for 106 and 107, respectively.

Crystals with molecular formula $\mathrm{ATCO}_{3} \mathrm{~F}(\mathrm{~A}=\mathrm{K}, \mathrm{Rb} ; \mathrm{T}=\mathrm{Zn}, \mathrm{Cd})$ were synthesized by solvothermal reactions under subcritical conditions $[141,142,143] . \mathrm{KCdCO}_{3} \mathrm{~F}(\mathbf{1 0 8}), \mathrm{RbCdCO}_{3} \mathrm{~F}$ (109), $\mathrm{KZnCO}_{3} \mathrm{~F}(\mathbf{1 1 0})$, and $\mathrm{RbZnCO}_{3} \mathrm{~F}(\mathbf{1 1 1})$ are isostructural (acentric space group $P \overline{6} c 2$ ) and 
feature alternating $[\mathrm{AF}]_{\infty}(\mathrm{A}=\mathrm{K}, \mathrm{Rb})$ and $\left[\mathrm{TCO}_{3}\right]_{\infty}(\mathrm{T}=\mathrm{Zn}, \mathrm{Cd})$ layers connected by infinite $\mathrm{T}-\mathrm{F}-\mathrm{T}(\mathrm{T}=\mathrm{Zn}, \mathrm{Cd})$ chains parallel to the $c$-axis (Figure 37). All compounds exhibit broad transparency ranging from the UV to the near IR. SHG measurements reveal type I phasematchable behavior in both the visible and the UV regions and efficiencies of ca. 4.58, 2.84, 1.76, and $0.83 \times \mathrm{KDP}$ for $\mathbf{1 0 8}, \mathbf{1 0 9}, \mathbf{1 1 0}$, and $\mathbf{1 1 1}$, respectively. The SHG performance was therefore modified by using different cations to vary the anionic group architectures.

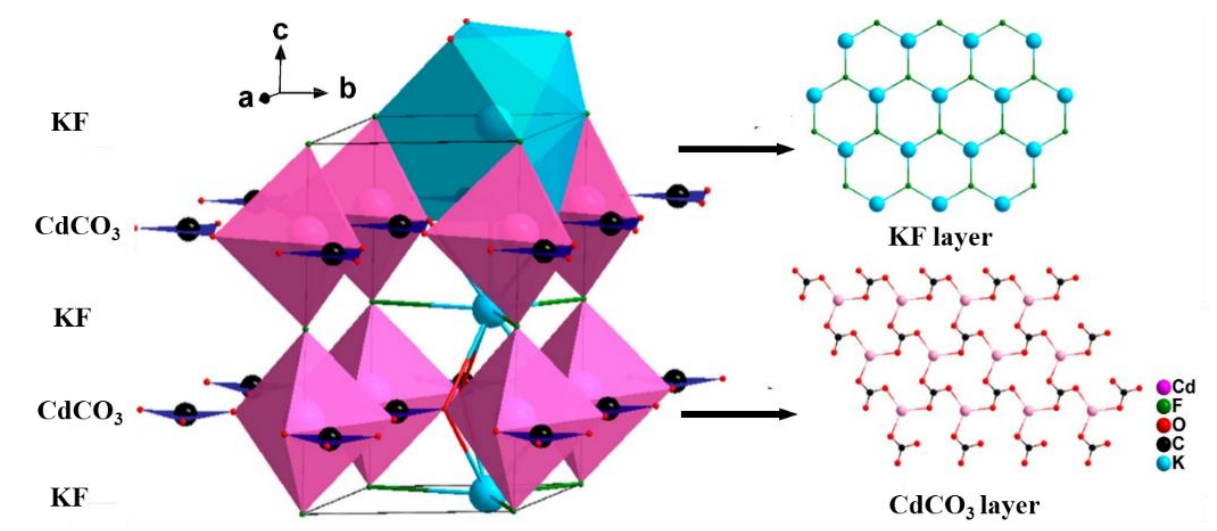

Figure 37. Crystal structure of $\mathrm{KCdCO}_{3} \mathrm{~F}$ (108) [141]. (c) 2015 American Chemical Society.

In addition to carbonate fluorides containing $(n-1) d^{10} \mathrm{~ns}^{0}$ transition-metal cations, compounds with $\mathrm{ns}^{2}$ main-group metal cations $\left(\mathrm{Pb}^{2+}, \mathrm{Sn}^{2+}\right.$, etc.) have also received attention. Second-order Jahn-Teller (SOJT) distorted polyhedra of stereoactive lone pair cations are beneficial in promoting an asymmetric crystal structure as well as a strong SHG response but may decrease the UV-transparency range (narrowing the bandgap); examples include $\mathrm{APbCO}_{3} \mathrm{~F}(\mathrm{~A}=$ $\mathrm{Rb}$ (112), $\mathrm{Cs}(\mathbf{1 1 3}))[144,145]$ and $\mathrm{K}_{2.7} \mathrm{~Pb}_{5.15}\left(\mathrm{CO}_{3}\right)_{5} \mathrm{~F}_{3}(\mathbf{1 1 4})(P \overline{6} 2 m)[146] .112$ and 113 were synthesized through solvothermal and conventional solid-state techniques by Halasyamani group, and both crystallize in the hexagonal $P \overline{6} 2 m$ system with $3 \mathrm{D}$ crystal structures consisting of cornershared $\left[\mathrm{PbO}_{6} \mathrm{~F}_{2}\right]$ polyhedra. The materials have absorption edges in the near-UV region. Crystal 113 exhibits the largest SHG response among the carbonates. Theoretical studies suggest that the 
extremely large SHG efficiency originates from the $\mathrm{p}-\pi$ interaction between $\mathrm{Pb}^{2+}$ and $\left[\mathrm{CO}_{3}\right]$ within the $\left[\mathrm{Pb}\left(\mathrm{CO}_{3}\right)\right]$ layers (Figure 38).

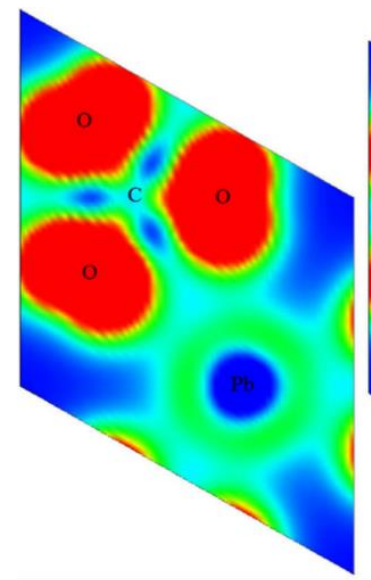

(a)

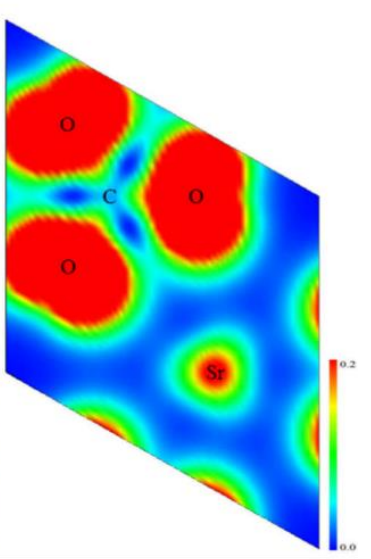

(b)

Figure 38. Partial charge density maps for compound 113 (a) and 95 (b) from $-4 \mathrm{eV}$ to the Fermi level. The electron density is represented ranging from blue (0.0 e/Å3) to red (0.2 e/Å3) [146]. @ 2013 American Chemical Society.

Metal carbonate fluorides can be synthesized by high-temperature solution, solvothermal or hydrothermal methods. The planar $\left[\mathrm{CO}_{3}\right]$ anionic groups with conjugated $\pi$-orbitals possess relatively large microscopic second-order susceptibilities and contribute to the moderate birefringence, which is beneficial for the generation of UV and deep-UV coherent light. In comparison to metal carbonates without additional anionic groups, metal carbonate fluorides can possess short absorption edges due to the existence of the $\mathrm{F}^{-}$anions. Reports on new UV and deepUV NLO metal carbonates are thus far very scarce partially due to the difficulty in single-crystal growth.

\section{Metal nitrates}

Metal nitrates can be prepared by relatively simple and energy-saving synthetic methods. However, metal nitrates readily dissolve in water, so studies of nitrates as UV or deep-UV NLO materials are relatively few to date. The crystal structures of metal nitrates all consist of isolated 
$\left[\mathrm{NO}_{3}\right]$ groups. Analogous to the $\left[\mathrm{BO}_{3}\right]$ group, the $\left[\mathrm{NO}_{3}\right]$ group possesses a similar planar triangular structure with $\pi$-conjugated molecular orbitals and a larger microscopic second-order susceptibility than that of the $\left[\mathrm{BO}_{3}\right]$ or $\left[\mathrm{CO}_{3}\right]$ groups, which means that metal nitrates with planar triangular $\left[\mathrm{NO}_{3}\right]$ may be promising candidates for NLO materials in the UV or deep-UV region (Table 7).

Table 7

NLO data for metal nitrates

\begin{tabular}{|c|c|c|c|c|c|}
\hline Compounds & $\begin{array}{l}\text { Space } \\
\text { group }\end{array}$ & $\begin{array}{l}\text { Structural } \\
\text { feature }\end{array}$ & Absorption edge & $\begin{array}{l}\text { SHG intensity } \\
(@ 1064 \mathrm{~nm})\end{array}$ & Ref. \\
\hline $\mathrm{Sr}_{2}(\mathrm{OH})_{3} \mathrm{NO}_{3}$ & $P \overline{6} 2 m$ & & $200 \mathrm{~nm}(6.20 \mathrm{eV})$ & $3.6 \times \mathrm{KDP}$ & {$[147]$} \\
\hline $\mathrm{Rb}_{2} \mathrm{Na}\left(\mathrm{NO}_{3}\right)_{3}$ & $P m c 2_{1}$ & & $262 \mathrm{~nm}(4.74 \mathrm{eV})^{a}$ & $5.0 \times \mathrm{KDP}$ & [148] \\
\hline $\mathrm{La}(\mathrm{OH})_{2} \mathrm{NO}_{3}$ & $P 2_{1}$ & & $260 \mathrm{~nm}(4.76 \mathrm{eV})^{a}$ & $5.0 \times \mathrm{KDP}$ & [149] \\
\hline $\mathrm{Y}(\mathrm{OH})_{2} \mathrm{NO}_{3}$ & $P 2_{1}$ & {$\left[\mathrm{NO}_{3}\right]$} & $257 \mathrm{~nm}(4.83 \mathrm{eV})^{a}$ & $5.5 \times \mathrm{KDP}$ & [149] \\
\hline $\mathrm{Gd}(\mathrm{OH})_{2} \mathrm{NO}_{3}$ & $P 2_{1}$ & & $256 \mathrm{~nm}(4.84 \mathrm{eV})^{a}$ & $5.6 \times \mathrm{KDP}$ & [149] \\
\hline$\left[\mathrm{Pb}_{4}(\mathrm{OH})_{4}\right]\left(\mathrm{NO}_{3}\right)_{4}$ & $C c$ & & $358 \mathrm{~nm}(3.46 \mathrm{eV})^{a}$ & $0.7 \times \mathrm{KDP}$ & {$[150-152]$} \\
\hline $\left.\mathrm{LaPb}_{8} \mathrm{O}(\mathrm{OH})_{10}\left(\mathrm{H}_{2} \mathrm{O}\right)\right]\left(\mathrm{NO}_{3}\right)_{7}$ & $C c$ & & $343 \mathrm{~nm}(3.61 \mathrm{eV})^{a}$ & $1.3 \times \mathrm{KDP}$ & {$[153]$} \\
\hline$\left[\mathrm{LaPb}_{8} \mathrm{O}(\mathrm{OH})_{10}\left(\mathrm{H}_{2} \mathrm{O}\right)\right]\left(\mathrm{NO}_{3}\right)_{7} \cdot 2 \mathrm{H}_{2} \mathrm{O}$ & $P 2{ }_{1} 2_{1} 2_{1}$ & & $346 \mathrm{~nm}(3.56 \mathrm{eV})^{a}$ & $1.1 \times \mathrm{KDP}$ & {$[153]$} \\
\hline
\end{tabular}

${ }^{a}$ Energy bandgap.

One remarkable example is $\mathrm{Sr}_{2}(\mathrm{OH})_{3} \mathrm{NO}_{3}(\mathbf{1 1 5})(P \overline{6} 2 m)$, which demonstrates the sole nitrate as the promising deep-UV nonlinear optical material to date [147]. 115 was obtained by a conventional hydrothermal method using $\operatorname{Sr}\left(\mathrm{NO}_{3}\right)_{2}$ and deionized water with the addition of $\mathrm{NaOH}$ and $\mathrm{NH}_{4} \mathrm{NO}_{3}$. The structure of $\mathbf{1 1 5}$ is built from $\left[\mathrm{SrO}_{3}(\mathrm{OH})_{6}\right]$ polyhedra and triangular $\left[\mathrm{NO}_{3}\right]$ groups (Figure 39). Noteworthy is the cooperative interaction of triangular $\left[\mathrm{SrO}_{3}\right]$ and $\left[\mathrm{NO}_{3}\right]$ which facilitates parallel $\left[\mathrm{NO}_{3}\right]$ alignment in the $a b$ plane and orientation in the same direction, favorable for the generation of a large macroscopic SHG response. 115 has a short-wavelength absorption edge below $200 \mathrm{~nm}$ and is phase-matchable with a strong SHG response ca. $3.6 \times$ KDP. In contrast to the other nitrates, crystalline $\mathrm{Rb}_{2} \mathrm{Na}_{(}\left(\mathrm{NO}_{3}\right)_{3}(\mathbf{1 1 6})\left(P m c 2_{1}\right)$ was synthesized through a solid-state 
reaction [148]. The material lacks hydroxyl groups and shows good chemical and thermal stability. Very interestingly, 116 exhibits a very large SHG response, $5.0 \times \mathrm{KDP}$, and an absorption edge of $262 \mathrm{~nm}(4.76 \mathrm{eV})$.

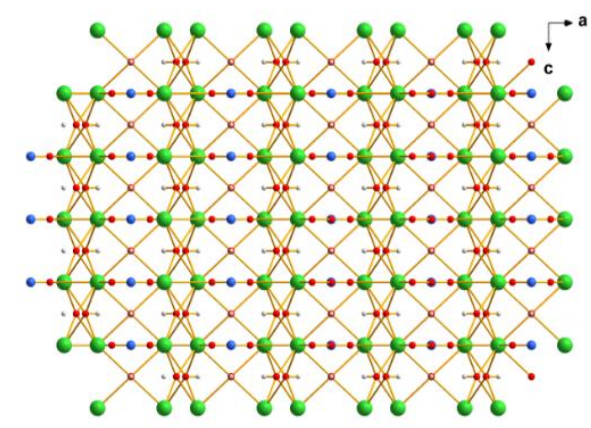

(a)

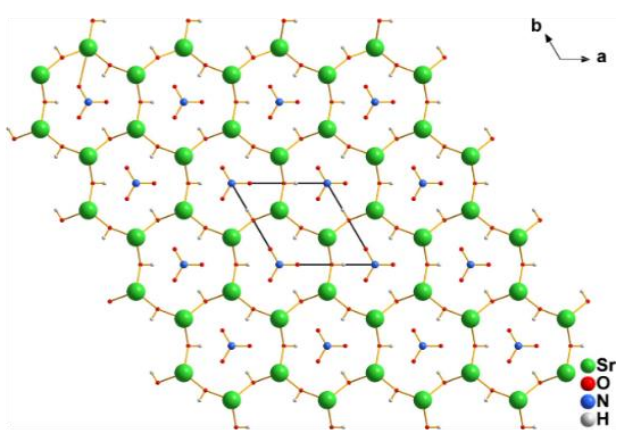

(b)

Figure 39. Crystal structures of $\mathrm{Sr}_{2}(\mathrm{OH})_{3} \mathrm{NO}_{3}$ (115) (a) along the $b$-axis and (b) along the $c$-axis [147]. (C) 2015 Royal Society of Chemistry

Crystals of $\mathrm{Ln}(\mathrm{OH})_{2} \mathrm{NO}_{3}\left(\mathrm{Ln}=\mathrm{La}(\mathbf{1 1 7}), \mathrm{Y}(\mathbf{1 1 8}), \mathrm{Gd}(\mathbf{1 1 9}) ; P 2_{1}\right)$ were synthesized through hydrothermal reactions from a mixture of $\mathrm{NaNO}_{3} / \mathrm{KNO}_{3}, \mathrm{NaOH} / \mathrm{KOH}, \mathrm{Ln}\left(\mathrm{NO}_{3}\right)_{3} \cdot 6 \mathrm{H}_{2} \mathrm{O}$, and $\mathrm{H}_{2} \mathrm{O}$ [149]. These three nitrates crystallize in the NCS space group $P 2_{1}$ and are isostructural, exhibiting layered structures where each layer contains $\left[\mathrm{LnO}_{9}\right](\mathrm{RE}=\mathrm{La}, \mathrm{Y}$, and $\mathrm{Gd})$ polyhedra and $\left[\mathrm{NO}_{3}\right]$ triangles, and featuring two different ligation modes of the $\left[\mathrm{NO}_{3}\right]$ groups (Figure 40). Crystals 117119 all possess large SHG responses (5, 5.5, and 5.6 times that of KDP, respectively) and are phase-matchable in the visible and UV regions. The theoretical calculations based on the anionic group theory suggest that the macroscopic SHG coefficients for 117-119 originate from a geometrical addition of the microscopic second-order susceptibility of the planar $\left[\mathrm{NO}_{3}\right]$ group (Figure 41). In addition, they exhibit a wide transparency range extending from the UV to the near IR. 


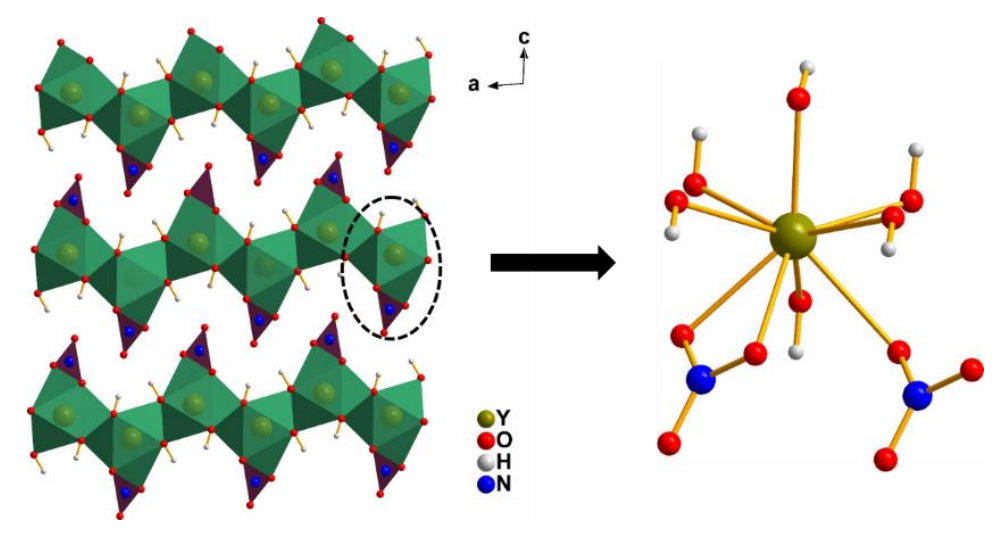

Figure 40. Crystal structure of $\mathrm{Y}(\mathrm{OH})_{2} \mathrm{NO}_{3}$ (118) [149]. (c) 2017 American Chemical Society.

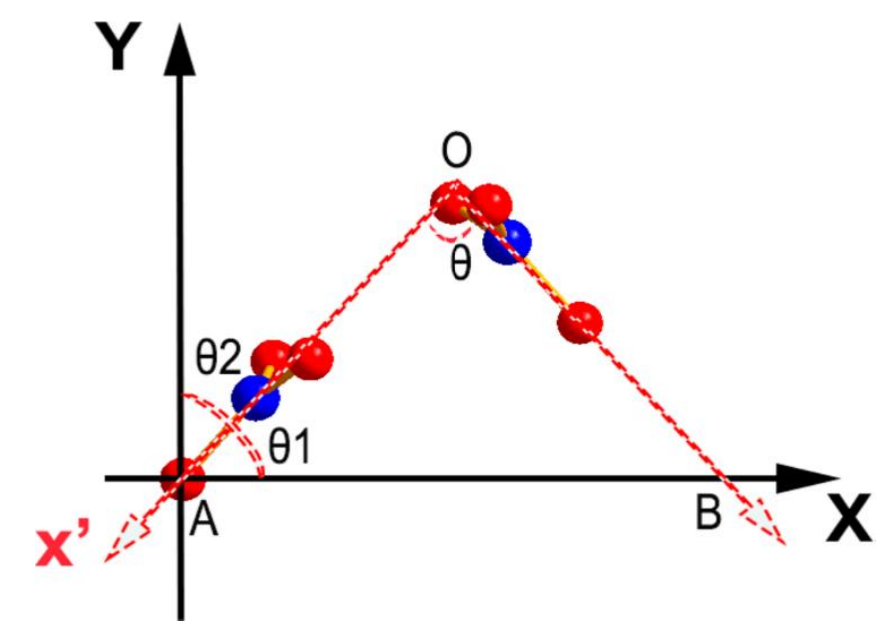

Figure 41. Macroscopic coordinates $(\mathrm{X}-\mathrm{Y})$ of the crystal and microscopic coordinates $\left(\mathrm{x}^{\prime}-\mathrm{y}\right.$ ') of the $\left[\mathrm{NO}_{3}\right]$ groups [149]. (C) 2017 American Chemical Society.

The lead dication with its $\mathrm{ns}^{2}$ lone-pair electrons is a popular addition to nitrates in an attempt to obtain NLO materials with strong SHG responses. Lead-containing compounds have great structural variability, examples including $\left[\mathrm{Pb}_{4}(\mathrm{OH})_{4}\right]\left(\mathrm{NO}_{3}\right)_{4} \quad(\mathbf{1 2 0}) \quad(C c) \quad[150,151,152]$, $\left.\mathrm{LaPb}_{8} \mathrm{O}(\mathrm{OH})_{10}\left(\mathrm{H}_{2} \mathrm{O}\right)\right]\left(\mathrm{NO}_{3}\right)_{7}(\mathbf{1 2 1})(C c)[153]$, and $\left[\mathrm{LaPb} b_{8} \mathrm{O}(\mathrm{OH})_{10}\left(\mathrm{H}_{2} \mathrm{O}\right)\right]\left(\mathrm{NO}_{3}\right)_{7} \cdot 2 \mathrm{H}_{2} \mathrm{O} \quad(\mathbf{1 2 2})$ $\left(P 22_{1} 2_{1}\right)$ [153]. All materials have an absorption edge in the near-UV region. 120 was synthesized through a conventional hydrothermal reaction. It is constructed from $\left[\mathrm{Pb}_{4}(\mathrm{OH})_{4}\right]^{4+}$ cubanes and $\left[\mathrm{NO}_{3}\right]$ groups forming the overall 3D structure via $\mathrm{Pb}-\mathrm{O}$ bonds. The $\mathrm{SHG}$ response with $1064 \mathrm{~nm}$ radiation is ca. $0.7 \times \mathrm{KDP}$ and is type I phase-matchable. This value is relatively small, due to the fact that the contributions from the $\left[\mathrm{NO}_{3}\right]$ groups and $\mathrm{Pb}-\mathrm{O}$ polyhedra are largely cancelled due 
to their unfavorable alignment. Rare-earth cations have unique coordination geometries that usually include irregular polyhedra with large dipole moments. 121 and $\mathbf{1 2 2}$ were obtained under subcritical hydrothermal conditions employing raw materials with different molar ratios. The two compounds show SHG efficiencies comparable to that of KDP. Theoretical calculations reveal that the lone-pair electrons of the $\mathrm{Pb}^{2+}$ cation make almost no contribution to the NLO response of 121 and 122, the SHG responses mainly arising from the $\left[\mathrm{NO}_{3}\right]$ groups.

Metal nitrates provide another SHG material option for the systematic design of NCS crystals in UV and deep-UV regions. Most metal nitrates have been obtained by hydrothermal means. The use of different reaction conditions such as varying the counterion, concentration of reagents in solution, and $\mathrm{pH}$ of the reaction media may result in metal nitrates with varying structures, particularly for the $\mathrm{Pb}$-containing nitrate system. In addition, metal nitrates containing $\mathrm{OH}^{-}$groups are susceptible to hydrolysis, so a significant challenge remains to develop insoluble nitrate NLO materials.

\section{Metal phosphates}

$\mathrm{KTiOPO}_{4}(\mathrm{KTP})(\mathbf{1 2 3})$, was the first SHG-active phosphate to be employed, and has been widely used since the 1970s [154]. However, the absorption edge of KTP is $350 \mathrm{~nm}$, which prohibits the generation of UV coherent light. It was not until quite recently that the first deep-UV NLO phosphates, $\mathrm{Ba}_{3} \mathrm{P}_{3} \mathrm{O}_{10} \mathrm{X}\left(\mathrm{X}=\mathrm{Cl}\left(\mathbf{1 2 4}, P c a 2_{1}\right)\right.$ or $\left.\mathrm{Br}\left(\mathbf{1 2 5}, P 2_{1} 2_{1} 2_{1}\right)\right)$, were reported [33]. Phosphates are potential UV NLO candidates due to their deep-UV transparency and the readiness with which they can be grown as bulk crystals. Recently, a number of metal phosphates with high thermal stability have been reported (Table 8).

\section{Table 8}

NLO data for metal phosphates 


\begin{tabular}{|c|c|c|c|c|c|}
\hline Compounds & Space group & Structural feature & Absorption edge & $\begin{array}{l}\text { SHG intensity } \\
(@ 1064 \mathrm{~nm})\end{array}$ & Ref. \\
\hline $\mathrm{LiCs}_{2} \mathrm{PO}_{4}$ & $C m c 2_{1}$ & Isolated $\mathrm{PO}_{4}$ & $174 \mathrm{~nm}(7.13 \mathrm{eV})$ & $2.6 \times \mathrm{KDP}$ & {$[155,156]$} \\
\hline $\mathrm{LiRb}_{2} \mathrm{PO}_{4}$ & $\mathrm{Cmc} 2_{1}$ & Isolated $\mathrm{PO}_{4}$ & $<170 \mathrm{~nm}(>7.29 \mathrm{eV})$ & $2.1 \times \mathrm{KDP}$ & {$[157]$} \\
\hline $\mathrm{LiPbPO}_{4}$ & Pna $_{1}$ & Isolated $\mathrm{PO}_{4}$ & $232 \mathrm{~nm}(5.34 \mathrm{eV})$ & $3 \times \mathrm{KDP}$ & {$[158]$} \\
\hline $\mathrm{RbMgPO}_{4} \cdot 6 \mathrm{H}_{2} \mathrm{O}$ & $P m n 2_{1}$ & Isolated $\mathrm{PO}_{4}$ & $288 \mathrm{~nm}(4.3 \mathrm{eV})^{a}$ & $0.76 \times \mathrm{ZnO}$ & [159] \\
\hline $\mathrm{CsMgPO}_{4} \cdot 6 \mathrm{H}_{2} \mathrm{O}$ & $P 6_{3} m c$ & Isolated $\mathrm{PO}_{4}$ & $258 \mathrm{~nm}(4.8 \mathrm{eV})^{a}$ & $1.13 \times \mathrm{ZnO}$ & [159] \\
\hline $\mathrm{K}_{4} \mathrm{Mg}_{4}\left(\mathrm{P}_{2} \mathrm{O}_{7}\right)_{3}$ & $P c$ & {$\left[\mathrm{P}_{2} \mathrm{O}_{7}\right]$ dimer } & $170 \mathrm{~nm}(7.29 \mathrm{eV})$ & $1.3 \times \mathrm{KDP}$ & {$[160]$} \\
\hline $\mathrm{Rb}_{4} \mathrm{Mg}_{4}\left(\mathrm{P}_{2} \mathrm{O}_{7}\right)_{3}$ & Ama2 & {$\left[\mathrm{P}_{2} \mathrm{O}_{7}\right]$ dimer } & $<200 \mathrm{~nm}(>6.2 \mathrm{eV})$ & $1.4 \times \mathrm{KDP}$ & {$[160]$} \\
\hline $\mathrm{Rb}_{2} \mathrm{Ba}_{3}\left(\mathrm{P}_{2} \mathrm{O}_{7}\right)_{2}$ & $P 2_{1} 2_{1} 2_{1}$ & {$\left[\mathrm{P}_{2} \mathrm{O}_{7}\right]$ dimer } & $<200 \mathrm{~nm}(>6.2 \mathrm{eV})$ & $0.3 \times \mathrm{KDP}$ & {$[161]$} \\
\hline $\mathrm{Cs}_{2} \mathrm{Ba}_{3}\left(\mathrm{P}_{2} \mathrm{O}_{7}\right)_{2}$ & $P 2_{1} 2_{1} 2_{1}$ & {$\left[\mathrm{P}_{2} \mathrm{O}_{7}\right]$ dimer } & $176 \mathrm{~nm}(7.05 \mathrm{eV})$ & Very small & {$[162]$} \\
\hline $\mathrm{CsLiCdP}_{2} \mathrm{O}_{7}$ & $P m c 2_{1}$ & {$\left[\mathrm{P}_{2} \mathrm{O}_{7}\right]$ dimer } & $<200 \mathrm{~nm}(>6.2 \mathrm{eV})$ & $1.5 \times \mathrm{KDP}$ & [163] \\
\hline $\mathrm{Ba}_{3} \mathrm{P}_{3} \mathrm{O}_{10} \mathrm{Cl}$ & $\operatorname{Pca}_{1}$ & {$\left[\mathrm{P}_{3} \mathrm{O}_{10}\right]$ trimer } & $180 \mathrm{~nm}(>6.89 \mathrm{eV})$ & $0.6 \times \mathrm{KDP}$ & {$[33]$} \\
\hline $\mathrm{Ba}_{3} \mathrm{P}_{3} \mathrm{O}_{10} \mathrm{Br}$ & $P 2{ }_{1}{ }_{1} 2_{1}$ & {$\left[\mathrm{P}_{3} \mathrm{O}_{10}\right]$ trimer } & $<200 \mathrm{~nm}(>6.2 \mathrm{eV})$ & $0.5 \times \mathrm{KDP}$ & {$[33]$} \\
\hline $\mathrm{Ba}_{5} \mathrm{P}_{6} \mathrm{O}_{20}$ & Pca $_{1}$ & {$\left[\mathrm{P}_{3} \mathrm{O}_{10}\right]$ trimer } & $167 \mathrm{~nm}(7.43 \mathrm{eV})$ & $0.8 \times \mathrm{KDP}$ & [164] \\
\hline $\mathrm{CsLa}\left(\mathrm{PO}_{3}\right)_{4}$ & $C 2$ & {$\left[\mathrm{PO}_{3}\right]_{\infty}$ chain } & $167 \mathrm{~nm}(7.43 \mathrm{eV})$ & $0.5 \times \mathrm{KDP}$ & [166] \\
\hline $\mathrm{KLa}\left(\mathrm{PO}_{3}\right)_{4}$ & $P 2_{1}$ & {$\left[\mathrm{PO}_{3}\right]_{\infty}$ chain } & $162 \mathrm{~nm}(7.65 \mathrm{eV})$ & $0.7 \times \mathrm{KDP}$ & {$[165]$} \\
\hline $\mathrm{Cs}_{6} \mathrm{Mg}_{6}\left(\mathrm{PO}_{3}\right)_{18}$ & $P 2_{1}$ & {$\left[\mathrm{PO}_{3}\right]_{\infty}$ chain } & $<190 \mathrm{~nm}(>6.52 \mathrm{eV})$ & $0.1 \times \mathrm{KDP}$ & [169] \\
\hline $\mathrm{RbBa}_{2}\left(\mathrm{PO}_{3}\right)_{5}$ & $P c$ & {$\left[\mathrm{PO}_{3}\right]_{\infty}$ chain } & $163 \mathrm{~nm}(7.61 \mathrm{eV})$ & $1.4 \times \mathrm{KDP}$ & {$[161]$} \\
\hline $\mathrm{KBa}_{2}\left(\mathrm{PO}_{3}\right)_{5}$ & $P c$ & {$\left[\mathrm{PO}_{3}\right]_{\infty}$ chain } & $167 \mathrm{~nm}(7.43 \mathrm{eV})$ & $0.9 \times \mathrm{KDP}$ & [167] \\
\hline $\mathrm{KPb}_{2}\left(\mathrm{PO}_{3}\right)_{5}$ & $P n$ & {$\left[\mathrm{PO}_{3}\right]_{\infty}$ chain } & $177 \mathrm{~nm}(7.02 \mathrm{eV})$ & $0.5 \times \mathrm{KDP}$ & [168] \\
\hline $\mathrm{RbPb}_{2}\left(\mathrm{PO}_{3}\right)_{5}$ & $P n$ & {$\left[\mathrm{PO}_{3}\right]_{\infty}$ chain } & N/A & $0.3 \times \mathrm{KDP}$ & {$[168]$} \\
\hline
\end{tabular}

${ }^{a}$ Energy bandgap.

SHG-active metal phosphates can be divided into three categories according to the phosphate/polyphosphate present: (a) $\left[\mathrm{PO}_{4}\right]$ group, including $\mathrm{LiCs}_{2} \mathrm{PO}_{4}(\mathbf{1 2 6})[155,156], \mathrm{LiRb}_{2} \mathrm{PO}_{4}$ (127) [157], $\mathrm{LiPbPO}_{4}$ (128) [158], $\mathrm{AMgPO}_{4} \cdot 6 \mathrm{H}_{2} \mathrm{O}$ (A = Rb (129), Cs (130)) [159]; (b) flexible $\left[\mathrm{P}_{\mathrm{x}} \mathrm{O}_{\mathrm{y}}\right]^{\mathrm{n}-}$ asymmetric groups, including $\mathrm{A}_{4} \mathrm{Mg}_{4}\left(\mathrm{P}_{2} \mathrm{O}_{7}\right)_{3}(\mathrm{~A}=\mathrm{K}(\mathbf{1 3 1}), \mathrm{Rb}(\mathbf{1 3 2}))[160], \mathrm{A}_{2} \mathrm{Ba}_{3}\left(\mathrm{P}_{2} \mathrm{O}_{7}\right)_{2}$ $(\mathrm{A}=\mathrm{Rb}(\mathbf{1 3 3}), \mathrm{Cs}(\mathbf{1 3 4}))[161,162], \mathrm{CsLiCdP}_{2} \mathrm{O}_{7}(\mathbf{1 3 5})[163], \mathrm{Ba}_{3} \mathrm{P}_{3} \mathrm{O}_{10} \mathrm{X}(\mathrm{X}=\mathrm{Cl}(\mathbf{1 2 4}), \mathrm{Br}(\mathbf{1 2 5}))$ [33], $\mathrm{Ba}_{5} \mathrm{P}_{6} \mathrm{O}_{20}(\mathbf{1 3 6})$ [164]; (c) infinite $\left[\mathrm{PO}_{3}\right]_{\infty}$ chains, including $\mathrm{ALa}\left(\mathrm{PO}_{3}\right)_{4}(\mathrm{~A}=\mathrm{K}(\mathbf{1 3 7}), \mathrm{Cs}(\mathbf{1 3 8}))$ $[165,166], \mathrm{ABa}_{2}\left(\mathrm{PO}_{3}\right)_{5}(\mathrm{~A}=\mathrm{K}(\mathbf{1 3 9}), \mathrm{Rb}(\mathbf{1 4 0}))[161,167], \mathrm{APb}_{2}\left(\mathrm{PO}_{3}\right)_{5}(\mathrm{~A}=\mathrm{K}(\mathbf{1 4 1}), \mathrm{Rb}(\mathbf{1 4 2}))$ [168], $\mathrm{Cs}_{6} \mathrm{Mg}_{6}\left(\mathrm{PO}_{3}\right)_{18}(\mathbf{1 4 3})$ [169]. 
Single crystals of 126 and 127 crystallizing in the NCS space group $C m c 2_{1}$ were grown by the TSSG method, their structures exhibiting 3D frameworks composed of isolated $\left[\mathrm{PO}_{4}\right]$, [ $\left.\mathrm{LiO}_{4}\right]$ tetrahedra and $\left[\mathrm{RbO}_{\mathrm{n}}\right]$ polyhedra (Figure 42) [155-157]. SHG measurements revealed that $\mathbf{1 2 6}$ and 127 display SHG responses that are ca. 2.6 and 2.1 times of KDP, respectively. It is noteworthy that the SHG merit of $\mathbf{1 2 6}$ is the largest reported to date for deep-UV SHG-active phosphates, and in addition it possesses an extremely short absorption edge of $174 \mathrm{~nm}(7.13 \mathrm{eV})$. The absorption edge of $\mathbf{1 2 7}$ is below $170 \mathrm{~nm}(>7.29 \mathrm{eV})$ and so, in comparison to $\mathbf{1 2 6}$, the rubidium example may be more suitable for deep-UV applications. Crystals of the acentric phosphate $\mathbf{1 2 8}\left(\right.$ Pna $\left.2_{1}\right)$, which features a SCALP cation $\mathrm{Pb}^{2+}$, were grown through spontaneous crystallization from hightemperature melts [158]. The material possesses a large SHG response $(3 \times \mathrm{KDP})$ and an absorption edge at $232 \mathrm{~nm}$, achieving a subtle balance between SHG response and UV transparency.

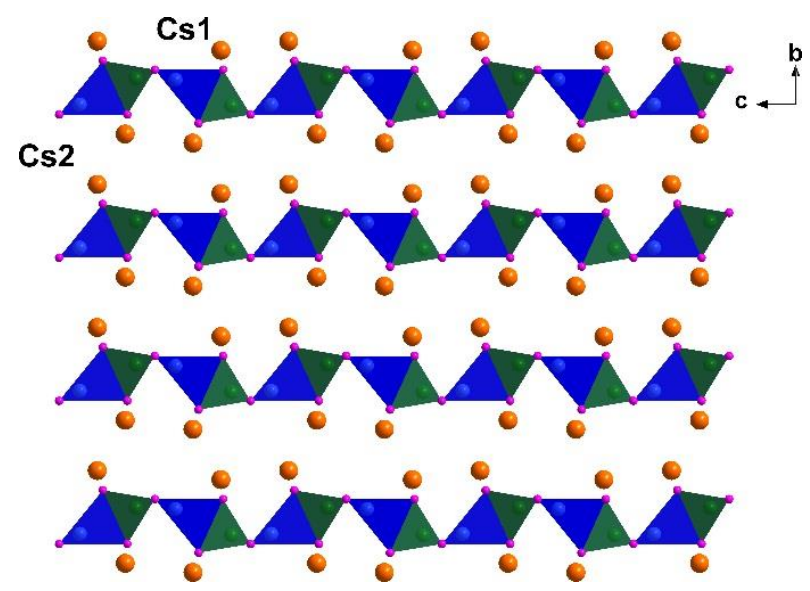

Figure 42. Crystal structure of $\mathrm{LiCs}_{2} \mathrm{PO}_{4}(\mathbf{1 2 6}) . \mathrm{LiO}_{4}$ (blue) and $\mathrm{PO}_{4}$ (green) groups are two distinct 4-connected nodes [155]. (C) 2016 American Chemical Society.

$\mathrm{AMgPO}_{4} \cdot 6 \mathrm{H}_{2} \mathrm{O}(\mathrm{A}=\mathrm{Rb}(\mathbf{1 2 9})$, $\mathrm{Cs}(\mathbf{1 3 0}))$ were synthesized by a soft hydrothermal method [159]. 129 has a one-layer struvite-like structure and crystallizes in the orthorhombic space group $P m n 2_{1}$, while $\mathbf{1 3 0}$ has a two-layer nickeline-like structure and crystallizes in the polar space group $P 6_{3} m c$ (Figure 43). SHG measurements revealed that crystals of $\mathbf{1 2 9}$ and $\mathbf{1 3 0}$ are not phase- 
matchable, with SHG efficiencies of 0.76 and $1.13 \times \mathrm{ZnO}$ (in the particle size range of $62-75 \mathrm{~mm}$ ), respectively. The energy bandgaps of $\mathbf{1 2 9}$ and $\mathbf{1 3 0}$ are $4.3 \mathrm{eV}(288 \mathrm{~nm})$ and $4.8 \mathrm{eV}(258 \mathrm{~nm})$, respectively.

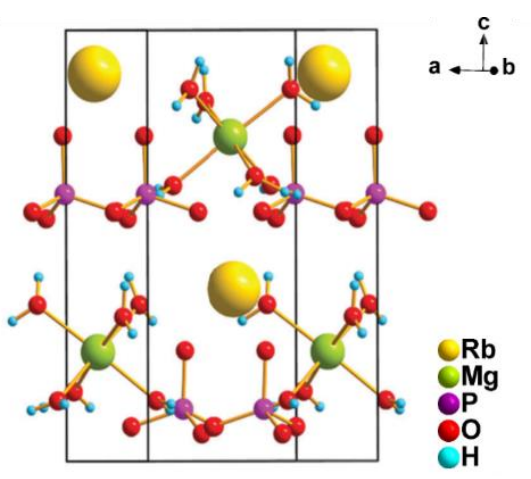

(a)

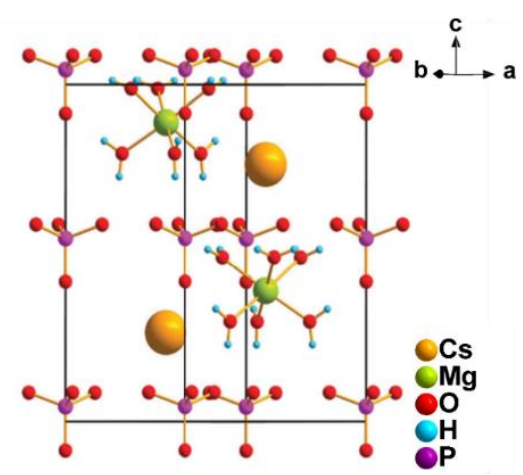

(b)

Figure 43. Crystal structures of (a) $\mathrm{RbMgPO}_{4} \cdot 6 \mathrm{H}_{2} \mathrm{O}$ (129) and (b) $\mathrm{CsMgPO}_{4} \cdot 6 \mathrm{H}_{2} \mathrm{O}$ (130) [159]. (c) 2016 Royal Society of Chemistry.

Crystals of acentric $\mathrm{A}_{4} \mathrm{Mg}_{4}\left(\mathrm{P}_{2} \mathrm{O}_{7}\right)_{3}(\mathrm{~A}=\mathrm{K}(\mathbf{1 3 1}), \mathrm{Rb}(\mathbf{1 3 2}))$ were grown from hightemperature solutions with $\mathrm{K}_{2} \mathrm{O} / \mathrm{Rb}_{2} \mathrm{O}-\mathrm{P}_{2} \mathrm{O}_{5}$ as the flux [160]. 131 and $\mathbf{1 3 2}$ are not isostructural, 131 crystallizing in the monoclinic space group $P c$ and 132 crystallizing in the orthorhombic space group Amm2. The former contains a $\left[\mathrm{Mg}_{4} \mathrm{P}_{6} \mathrm{O}_{21}\right]$ double-layer exhibiting two different orientations and with the layers connected by bent $\left[\mathrm{P}_{2} \mathrm{O}_{7}\right]$ groups (Figure 44), whereas the latter comprises a single orientation of the $\left[\mathrm{Mg}_{4} \mathrm{P}_{6} \mathrm{O}_{21}\right]$ double-layer with the $\left[\mathrm{P}_{2} \mathrm{O}_{7}\right]$ group connecting the doublelayers. Both materials exhibit absorption edges below $200 \mathrm{~nm}$ and relatively large SHG responses to $1064 \mathrm{~nm}$ radiation, $1.3 \times \mathrm{KDP}$ and $1.4 \times \mathrm{KDP}$ for $\mathbf{1 3 1}$ and 132, respectively. First-principles electronic structure calculations suggest that the NLO responses arise mainly from the presence of the corner-connected $\left[\mathrm{Mg}_{4} \mathrm{P}_{6} \mathrm{O}_{21}\right]$ double layers (Figure 45). 


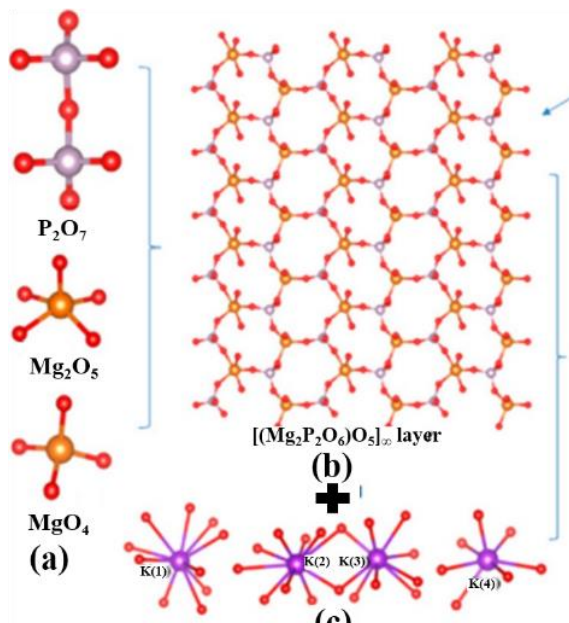

(c)

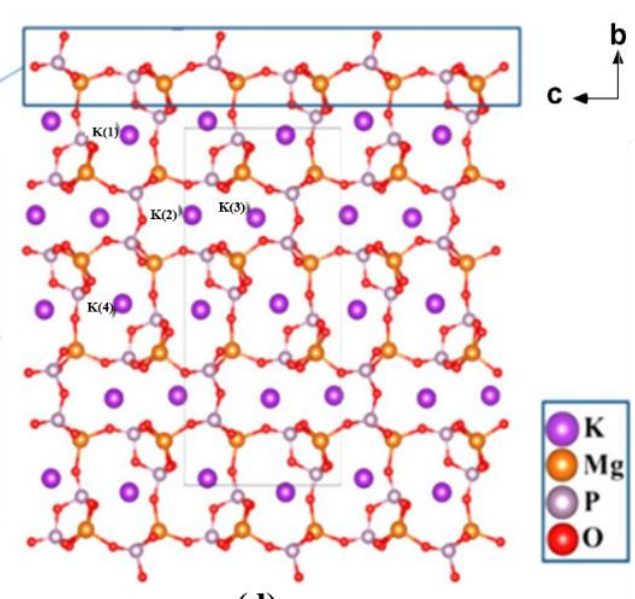

(d)

Figure 44. Crystal structure of $\mathrm{K}_{4} \mathrm{Mg}_{4}\left(\mathrm{P}_{2} \mathrm{O}_{7}\right)_{3}$ (131). (a) The $\mathrm{P}_{2} \mathrm{O}_{7}$ group and two $\mathrm{MgO}_{4} / \mathrm{MgO}_{5}$ polyhedra. (b) The $\left[\left(\mathrm{Mg}_{2} \mathrm{P}_{2} \mathrm{O}_{6}\right) \mathrm{O}_{5}\right]$ layer. (c) Coordination environment of the $\mathrm{K}$ atoms. (d) The $\left[\mathrm{Mg}_{4} \mathrm{P}_{6} \mathrm{O}_{21}\right]$ double layers stack along the $b$-axis and are connected by sharing $\mathrm{O}$ atoms to form a 3D framework with $\mathrm{K}^{+}$cations residing in the cavities [160]. (c) 2017 American Chemical Society.

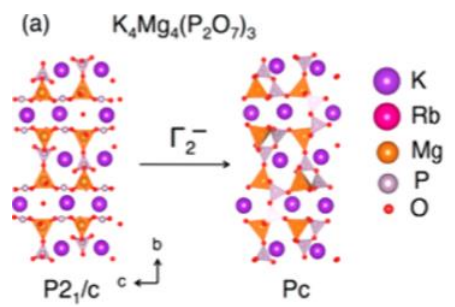

(b) $\quad \mathrm{Rb}_{4} \mathrm{Mg}_{4}\left(\mathrm{P}_{2} \mathrm{O}_{7}\right)_{3}$

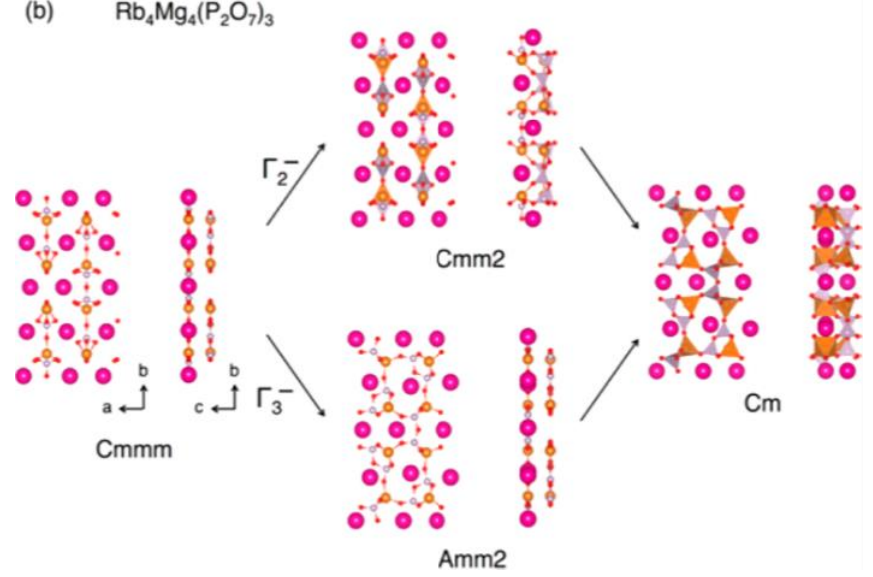

Figure 45. Symmetry adapted mode decomposition used to compute the specific acentric mode displacement (SAMD) of (a) $\mathrm{K}_{4} \mathrm{Mg}_{4}\left(\mathrm{P}_{2} \mathrm{O}_{7}\right)_{3}$ (131) and (b) $\mathrm{Rb}_{4} \mathrm{Mg}_{4}\left(\mathrm{P}_{2} \mathrm{O}_{7}\right)_{3}$ (132). The atomic displacements comprising the modes in $\mathrm{Rb}_{4} \mathrm{Mg}_{4}\left(\mathrm{P}_{2} \mathrm{O}_{7}\right)_{3}$ (132) are shown along two directions for clarity [160]. (c) 2017 American Chemical Society. 
Single crystals of $\mathbf{1 3 3}$ and $\mathbf{1 3 4}$ were grown through spontaneous crystallization from hightemperature melts. These isostructural compounds are polar (space group $P 2{ }_{1} 2_{1} 2_{1}$ ) and show weak SHG responses $[161,162]$. They exhibit a $3 \mathrm{D}$ framework that is composed of isolated $\left[\mathrm{P}_{2} \mathrm{O}_{7}\right]$, $\left[\mathrm{BaO}_{\mathrm{n}}\right]$, and $\left[\mathrm{CsO}_{\mathrm{n}}\right]$ polyhedra with absorption edges below $200 \mathrm{~nm}$.

Single crystals of $\mathbf{1 3 5}\left(P m c 2_{1}\right)$ were developed by spontaneous crystallization from a hightemperature melt of its polycrystalline powder. The structure of $\mathbf{1 3 5}$ can be described as a 3D $\left[\mathrm{CdP}_{2} \mathrm{O}_{7}\right]$ framework in which the metal cations are located in the cavities of the $3 \mathrm{D}$ framework [163]. 135 exhibits a significant SHG efficiency of $1.5 \times \mathrm{KDP}$ and is transparent down to $200 \mathrm{~nm}$; the large dipole moments of the distorted $\left[\mathrm{CdO}_{6}\right]$ octahedra and the $\left[\mathrm{P}_{2} \mathrm{O}_{7}\right]$ dimers within the framework contribute to its good NLO performance.

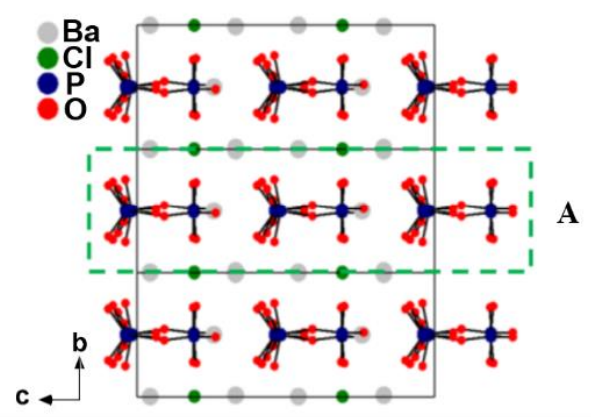

(a)

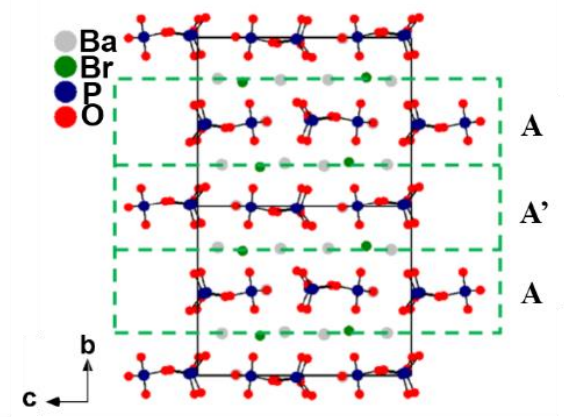

(b)

Figure 46. Crystal structures of (a) $\mathrm{Ba}_{3} \mathrm{P}_{3} \mathrm{O}_{10} \mathrm{Cl}$ (124) and (b) $\mathrm{Ba}_{3} \mathrm{P}_{3} \mathrm{O}_{10} \mathrm{Br}$ (125) [164]. (c) 2015 WILEY-VCH.

The non-isostructural $\mathrm{Ba}_{3} \mathrm{P}_{3} \mathrm{O}_{10} \mathrm{X}\left(\mathrm{X}=\mathrm{Cl}(\mathbf{1 2 4})\left(P c a 2_{1}\right), \mathrm{Br}(\mathbf{1 2 5})\left(P 2_{1} 2_{1} 2_{1}\right)\right)$ were prepared by a high-temperature solid-state route [33]. Their structures contain $\left[\mathrm{P}_{3} \mathrm{O}_{10}\right]$ anions that are isolated from each other by $\mathrm{Ba}^{2+}$ cations and $\mathrm{Cl}^{-} / \mathrm{Br}^{-}$anions. The sheet-like structures possess an $A A A$ stacking sequence for $\mathbf{1 2 4}$ and an $A^{\prime} A A^{\prime} A$ stacking sequence for $\mathbf{1 2 5}$ (Figure 46). 124 and 125 display moderate powder SHG intensities with type I phase-matchable behavior and are transparent to $\lambda=180 \mathrm{~nm}$ and $\lambda<200 \mathrm{~nm}$, respectively. DFT calculations and SHG coefficient 
analyses reveal that their SHG responses originate from the cooperation of asymmetric $\left[\mathrm{P}_{3} \mathrm{O}_{10}\right]$ anion, $\mathrm{Ba}^{2+}$ cation, and $\mathrm{Cl}^{-} / \mathrm{Br}^{-}$anion (Figure 47) [33].
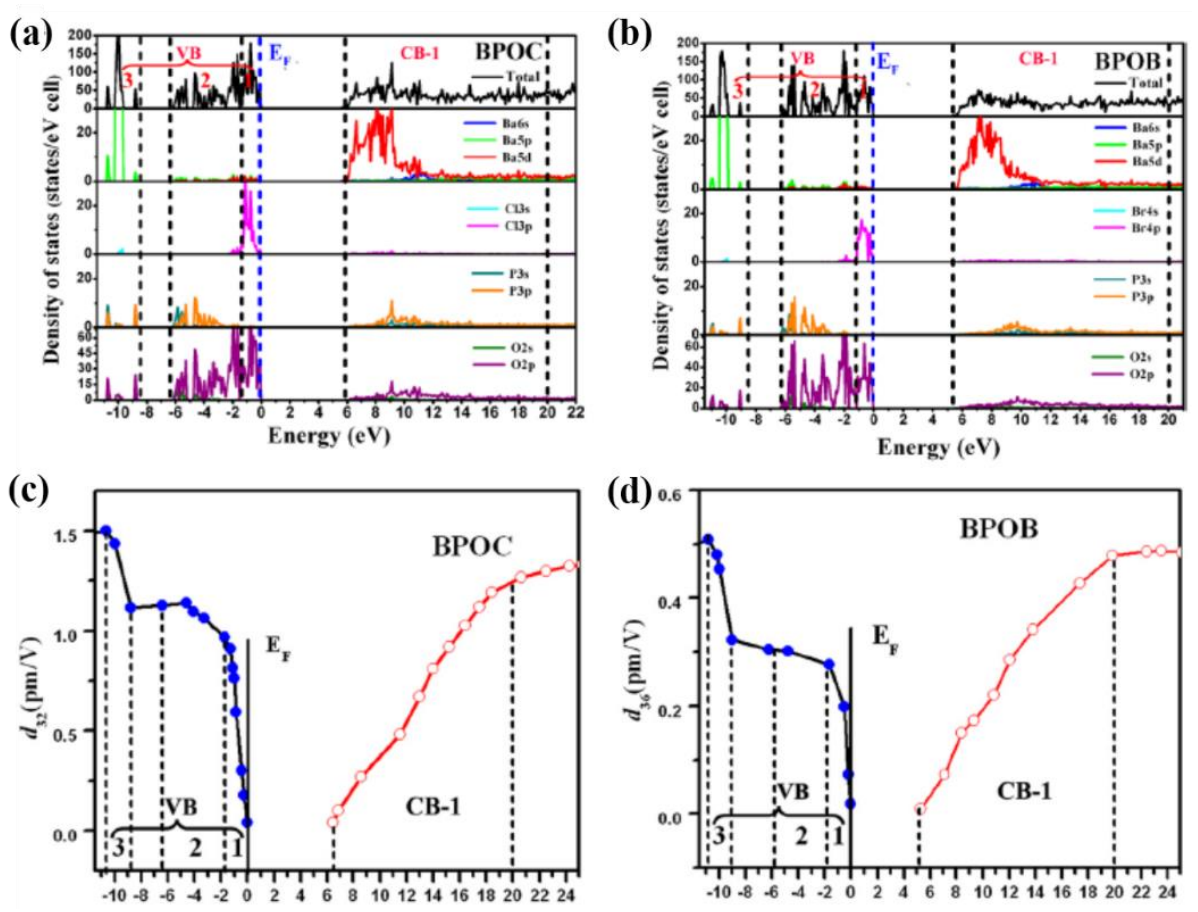

Figure 47. Total and partial densities of states of $\mathbf{1 2 4}$ (a) and $\mathbf{1 2 5}$ (b); numbers represent different band regions. Cutoff-energy-dependent static SHG coefficient of 124 (c) and 125 (d) [33]. (c) 2014 American Chemical Society.

Single crystals of $\mathbf{1 3 6}$ were grown through spontaneous crystallization in the presence of a $\mathrm{Cs}_{2} \mathrm{O}-\mathrm{P}_{2} \mathrm{O}_{5}$ flux [164]. Its structure consists of isolated $\left[\mathrm{P}_{3} \mathrm{O}_{10}\right]$ anions that are separated by $\mathrm{Ba}^{2+}$ cations, and an overall sheet-like topology with a $A B C B^{\prime} A B C B^{\prime}$ stacking sequence (Figure 48). The material is type I phase-matchable with a SHG efficiency of $0.8 \times \mathrm{KDP}$ and a very short absorption edge of $167 \mathrm{~nm}(7.43 \mathrm{eV})$. This result is in striking contrast with the commonly accepted viewpoint that halide ions are necessary for blue-shifted absorption edges. First-principles calculations by the plane-wave pseudopotential method suggest that $\left[\mathrm{P}_{3} \mathrm{O}_{10}\right]^{5-}$ groups mainly determine the optical response for $\mathbf{1 3 6 .}$ 


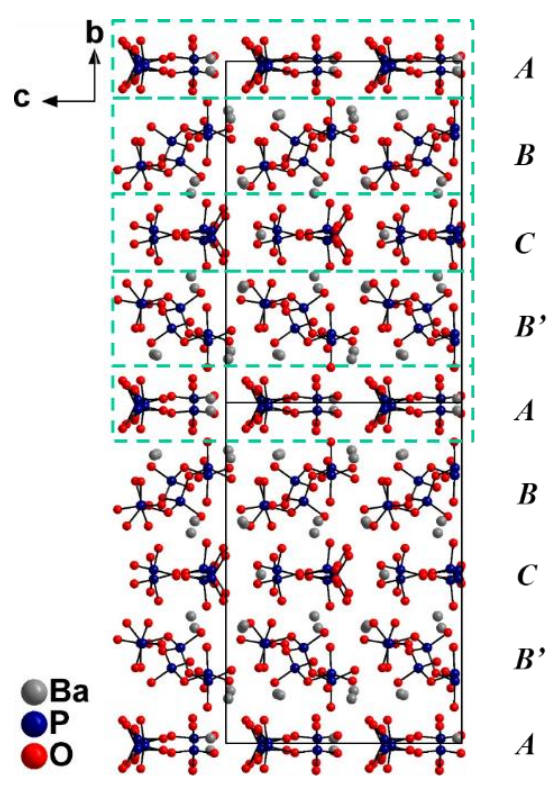

Figure 48. Crystal structure of $\mathrm{Ba}_{5} \mathrm{P}_{6} \mathrm{O}_{20}$ (136) [164]. (C) 2015 WILEY-VCH.

The two asymmetric phosphates $137\left(P 2_{1}\right)$ and $138(C 2)$, which feature $\left[\mathrm{PO}_{3}\right]_{\infty}$ chains formed by condensation of $\left[\mathrm{PO}_{4}\right]$ units, are deep-UV NLO materials $[165,166]$. Centimeter-size single crystals of 137 and 138 were grown through the flux method and slow cooling. The $\mathrm{P}-\mathrm{O}$ chains of $\mathbf{1 3 8}$ are helical and run along the symmetrical $b$-axis, while the corresponding chains of $\mathbf{1 3 7}$ zigzag along the $c$-axis. $\mathbf{1 3 7}$ has an extremely short absorption edge of $162 \mathrm{~nm}(7.65 \mathrm{eV})$, while the absorption edge for $\mathbf{1 3 8}$ is also short at $167 \mathrm{~nm}(7.43 \mathrm{eV})$. Powder SHG measurements revealed efficiencies of 0.7 and $0.5 \times$ KDP for 137 and $\mathbf{1 3 8}$, respectively, with the former compound shown to be type I phase-matchable in the visible region, unlike the latter.

The isostructural materials 139 and $\mathbf{1 4 0}$ both in $P c$ space group were prepared from hightemperature melts $[161,167]$; their crystal configurations are composed of infinite $1 \mathrm{D}\left[\mathrm{PO}_{3}\right]_{\infty}$ chains (Figure 49). 140 and 139 exhibit SHG responses of 1.4 and $0.9 \times$ KDP, respectively, while their absorption edges are $163 \mathrm{~nm}(7.61 \mathrm{eV})$ and $167 \mathrm{~nm}(7.43 \mathrm{eV})$, respectively, resulting in a desirable balance between short UV absorption edges and large SHG responses for these two 
crystals. Theoretical calculations assigned the enhanced macroscopic SHG responses of 139 and 140 to the presence of the $1 \mathrm{D}\left[\mathrm{PO}_{3}\right]_{\infty}$ chains.

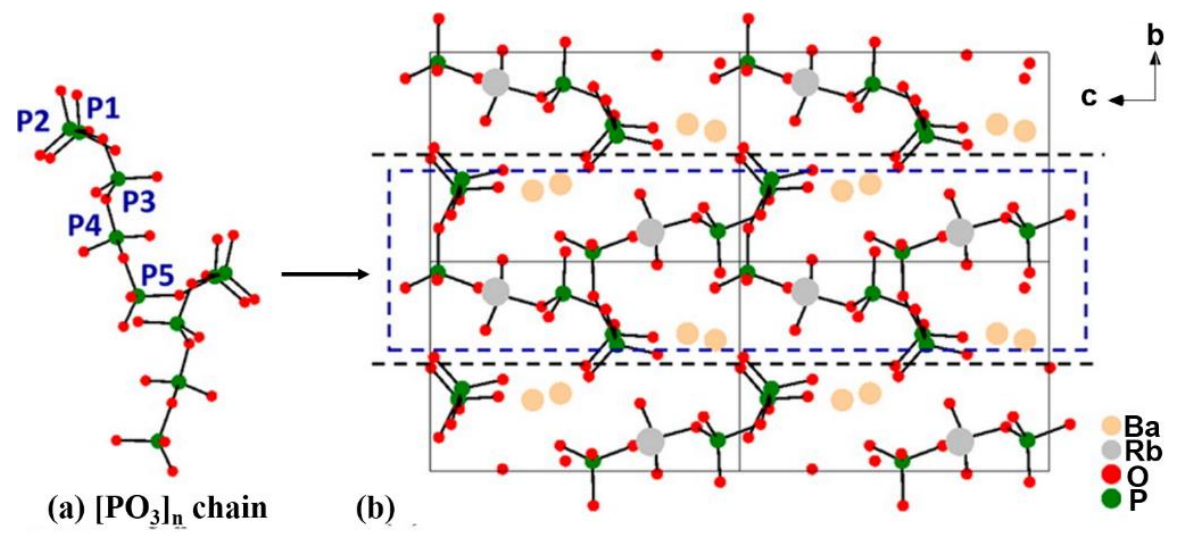

Figure 49. Crystal structure of $\mathrm{RbBa}_{2}\left(\mathrm{PO}_{3}\right)_{5}$ (140) [161]. (C) 2014 American Chemical Society.

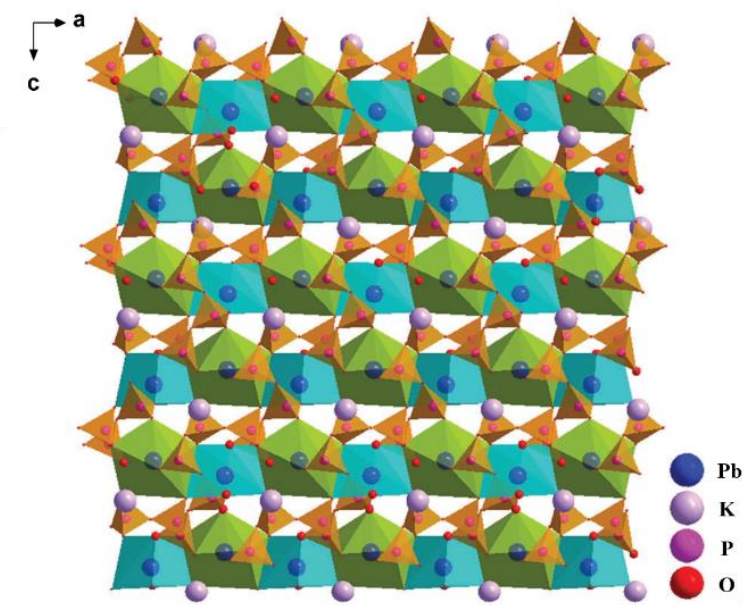

Figure 50. Crystal structure of $\mathrm{KPb}_{2}\left(\mathrm{PO}_{3}\right)_{5}$ (141) [168]. (c) 2016 Royal Society of Chemistry.

Compounds 141 and 142 with space group $P n$ exhibit 3D network structures containing two kinds of 1D chains formed by $\left[\mathrm{PO}_{4}\right]$ and $\left[\mathrm{PbO}_{\mathrm{n}}\right]$, respectively (Figure 50) [168]. The crystals of 141 were grown using traditional HTSS techniques with $\mathrm{K}_{2} \mathrm{CO}_{3}, \mathrm{PbO}$ and $\mathrm{NH}_{4} \mathrm{H}_{2} \mathrm{PO}_{4}$ as reagents. SHG measurements indicate that both have moderate powder SHG responses $(0.5$ and 0.3 times those of KDP, respectively) with type I phase-matchable behavior. Remarkably, 141 exhibits an absorption edge of $177 \mathrm{~nm}(7.02 \mathrm{eV})$, which is the shortest wavelength of Pb-containing NLO- 
active crystals. Theoretical studies suggested that the bandgap of $\mathbf{1 4 1}$ exhibits minimal red shift due to its weak distortion and stereochemical activity of the lead atom.

Single crystals of 143 in the NCS space group $P 2{ }_{1}$ were grown through a HTSS reaction using CsF- $\mathrm{P}_{2} \mathrm{O}_{5}$ as the flux. In comparison to the $\left[\mathrm{PO}_{3}\right]_{\infty}$ chains in $\mathbf{1 3 7}$ and 138, the 3D anionic framework of 143 includes a three-layer arrangement and a $2_{1}$ helical axis in the $b$-axis direction, which results in an elongated $b$-axis [169]. 143 displays a very weak response in the visible region, and in the UV region it is type I phase-matchable with a weak SHG intensity of $0.1 \times \mathrm{KDP}$. Its UV absorption edge is below $190 \mathrm{~nm}$, which was mainly ascribed to electronic transitions between the $\mathrm{O}$ and $\mathrm{P}$ atoms.

Many metal phosphates have been explored as potential UV and deep-UV NLO crystals in recent years. Because the $\sigma$-bonded $\mathrm{P}-\mathrm{O}$ groups do not favor large microscopic SHG coefficients, many structural design strategies have been explored to enhance the SHG response of metal phosphates while maintaining the deep-UV transparency. Metal phosphates show good thermal stabilities and can be easily grown as sizable crystals, which makes them attractive candidates for UV and deep-UV NLO crystals.

\section{Summary and outlook}

A number of conclusions can be drawn from examining the "state of play" of UV and deepUV second-order NLO inorganic crystals. (1) UV and deep-UV NLO materials are still dominated by metal borates, especially those containing nontoxic elements. Metal borates containing halides have a high probability of NCS structures and show short absorption edges. Hydrated borates

possessing good SHG properties are available through facile synthetic methods, and substitution of $\mathrm{OH}^{-}$by $\mathrm{F}^{-}$in this class of crystals could provide a new route to an enormous number of efficient 
NLO crystals. Metal borates with mixed anionic groups have good potential for improvement in the transparency/optical nonlinearity trade-off. (2) The limited results thus far suggest that metal carbonates can have large microscopic second-order susceptibilities and moderate birefringence. However, reports on new UV and deep-UV NLO metal carbonates are still scarce, primarily due to the difficulty in effecting single-crystal growth. (3) Metal nitrates are another option for systematic design of NCS crystals with large SHG responses in the UV and deep-UV regions that warrants increased study. (4) Metal phosphates invariably display wide UV transparency and as a result a range of structural design strategies have been explored to enhance the SHG response.

Structure-property correlations of NLO crystals are beginning to be established. It is clear that the NLO performance of these crystals is mainly determined by the density, alignment and configuration of the SHG-active building blocks within the structures such as the $\left[\mathrm{BO}_{3}\right],\left[\mathrm{NO}_{3}\right]$, $\left[\mathrm{CO}_{3}\right]$, and $\left[\mathrm{PO}_{4}\right]$ anions. The size and coordination geometry of the metal cations may also exert a crucial influence on the arrangement of the NLO-active units and consequently the optical properties of the NLO crystals. Additional insight and understanding and the continual development of structure-property correlations are critically important to the rational design of new NLO crystals with excellent UV SHG performance.

UV and deep-UV NLO crystals can be prepared by a variety of synthetic procedures such as the HTSS, hydrothermal, solvothermal and solution evaporation methods. However, the preparation of well-defined single crystals of large size and high quality is still a significant challenge. Thus, in the future considerable effort should be devoted to the development of facile and energy-saving routes to the growth of single crystals of sufficient size and quality, and to enhancing the key characteristics of crystals used in UV and deep-UV regions, such as chemical stability, mechanical strength, optical transparency, SHG efficiency and phase matchability, in 
order to pave the way for the transformation of the progress thus far in SHG-active crystals to their practical technological applications in optoelectric materials and devices.

\section{Acknowledgments}

This research was financially supported by the National Natural Science Foundation of China (Nos. 51432006, 50925207 and 51172100), the Ministry of Science and Technology of China (No. 2011DFG52970), the Ministry of Education of China for the Changjiang Innovation Research Team (No. IRT13R24), the Ministry of Education and the State Administration of Foreign Experts Affairs for the 111 Project (No. B13025), and the Innovation Program of Shanghai Municipal Education Commission. M.G.H. and C.Z. thank the Australian Research Council for support. 


\section{References}

[1] C. Monroe, Nature, 416 (2002) 238.

[2] X.X. Jiang, L. Kang, S.Y. Luo, P.F. Gong, M.H. Lee, Z.S. Lin, Int. J. Mod. Phys. B, 28 (2014) 1430018.

[3] M.S. William, M. Jyotirmoy, Laser Material Processing; Springer: New York, 2010.

[4] P. Becker, Adv. Mater., 10 (1998) 979.

[5] D.A. Keszler, Curr. Opin. Solid State Mater. Sci., 1 (1996) 204.

[6] K.B. Eisenthal, Chem. Rev., 106 (2006) 1462.

[7] I. Chung, M.G. Kanatzidis, Chem. Mater, 26 (2014), 849.

[8] K.A. Green, M.P. Cifuentes, M. Samoc, M.G. Humphrey, Coord. Chem. Rev., 255 (2011) 2530.

[9] Z. Li, Q.Q. Li, J.G. Qin, Polym. Chem., 2 (2011) 2723.

[10] C. Wang, T. Zhang, W.B. Lin, Chem. Rev., 112 (2012) 1084.

[11] C.T. Chen, B.C. Wu, A.D. Jiang, G.M. You, Sci. Sin., Ser. B, 28 (1985) 235.

[12] D. Eimerl, L. Davis, S. Velsko, E.K. Graham, J. Appl. Phys., 62 (1987) 1968.

[13] C.T. Chen, Y.C. Wu, A.D. Jiang, B.C. Wu, G.M. You, R.K. Li, S.J. Lin, J. Opt. Soc. Am. B, 6 (1989) 616.

[14] H. Konig, R. Hoppe, Z. Anorg. Allg. Chem., 439 (1978) 71.

[15] Y. Mori, I. Kuroda, S. Nakajima, T. Sasaki, S. Nakai, Appl. Phys. Lett., 67 (1995) 1818.

[16] I. Shoji, H. Nakamura, R. Ito, T. Kondo, M. Yoshimura, Y. Mori, T. Sasaki, J. Opt. Soc. Am. B, 18 (2001) 302 .

[17] Y.C. Wu, T. Sasaki, N. Nakai, A. Yokotani, H.G. Tang, C.T. Chen, Appl. Phys. Lett., 62 (1993) 2614.

[18] J. Krogh-Moe, Acta Crystallogr., Sect. B: Struct. Crystallogr. Cryst. Chem. B30 (1974) 1178.

[19] C.T. Chen, G.L. Wang, X.Y. Wang, Z.Y. Xu, Appl. Phys. B: Lasers Opt., 97 (2009) 9.

[20] C.T. Chen, Z.Y. Xu, D.Q. Deng, J. Zhang, G.K.L. Wong, B.C. Wu, N. Ye, D.Y. Tang, Appl. Phys. Lett., 68 (1996) 2930.

[21] S.P. Guo, Y. Chi, G.C. Guo, Coord. Chem. Rev., 335 (2017) 44. 
[22] C.L. Hu, J.G. Mao, Coord. Chem. Rev., 288 (2015) 1.

[23] K.M. Ok, Acc. Chem. Res., 49 (2016) 2774.

[24] R.G. Pearson, J. Mol. Struct.: THEOCHEM, 103 (1983) 25.

[25] M. Kunz, I.D. Brown, J. Solid State Chem., 115 (1995) 395.

[26] H.L. Jiang, S.P. Huang, Y. Fan, J.G. Mao, W.D. Cheng, Chem. Eur. J., 14 (2008) 1972.

[27] D.W. Lee, S.B. Kim, K.M. Ok, Dalton Trans., 41 (2012) 8348.

[28] J.L. Song, C.L. Hu, X. Xu, F. Kong, J.G. Mao, Angew. Chem. Int. Ed., 54 (2015) 3679.

[29] W.J. Yao, R. He, X.Y. Wang, Z.S. Lin, C.T. Chen, Adv. Opt. Mater., 2 (2014) 411.

[30] T.T. Tran, H.W. Yu, J.M. Rondinelli, K.R. Poeppelmeier, P.S. Halasyamani, Chem. Mater., 28 (2016) 5238.

[31] Y. Yang, X.X. Jiang, Z.S. Lin, Y.C. Wu, Crystals, 7 (2017) 95.

[32] L. Kang, S.Y. Luo, H.W. Huang, N. Ye, Z.S. Lin, J.G. Qin, C.T. Chen, J. Phys. Chem. C, 117 (2013) 25684.

[33] P. Yu, L.M. Wu, L.J. Zhou, L. Chen, J. Am. Chem. Soc., 136 (2014) 480.

[34] X.X. Jiang, S.Y. Luo, L. Kang, P.F. Gong, H.W. Huang, S.C. Wang, Z.S. Lin, C.T. Chen, ACS Photonics, 2 (2015) 1183.

[35] Y. Wang, S.L. Pan, Coord. Chem. Rev., 323 (2016) 15.

[36] A. Tressaud, K.R. Poeppelmeier, Photonic and Electronic Properties of Fluoride Materials, 1st ed., Elsevier, Amsterdam, The Netherlands, Oxford, U.K., and Cambridge, MA, U.S.A., 2016.

[37] C.T. Chen, S.Y. Luo, X.Y. Wang, G.L. Wang, X.H. Wen, H.X. Wu, X. Zhang, Z.Y. Xu, J. Opt. Soc. Am. B, 26 (2009) 1519.

[38] H.W. Huang, C.T. Chen, X.Y. Wang, Y. Zhu, G.L. Wang, X. Zhang, L.R. Wang, J.Y. Yao, J. Opt. Soc. Am. B, 28 (2011) 2186.

[39] C.T. Chen, Y.B. Wang, B.C. Wu, K.C. Wu, W.L. Zeng, L.H. Yu, Nature, 373 (1995) 322.

[40] Y.N. Xia, C.T. Chen, D.Y. Tang, B.C. Wu, Adv. Mater. 7 (1995) 79.

[41] C.T. Chen, in Materials for Nonlinear Optics: Chemical Perspectives, S.R. Marder, J.E. Sohn, and G.D. Stucky, eds, American Chemical Society, Washington, D.C., U.S.A., 1991, pp 360-379.

[42] C.T. Chen, Y.C. Wu, R.K. Li, Chin. Phys. Lett., 2 (1985) 389. 
[43] C.T. Chen, T. Sasaki, R.K. Li, Y.C. Wu, Z.S. Lin, Y. Mori, Z.G. Hu, J.Y. Wang, G. Aka, M. Yoshimura, Y. Kaneda, Nonlinear Optical Borate Crystals, Principals and Applications; WileyVCH: New York, NY, USA, 2012.

[44] S.C. Wang, N. Ye, W. Li, D. Zhao, J. Am. Chem. Soc., 132 (2010) 8779.

[45] S.C. Wang, N. Ye, J. Am. Chem. Soc., 133 (2011) 11458.

[46] H.W. Huang, L.J. Liu, S.F. Jin, W.J. Yao, Y.H. Zhang, C.T. Chen, J. Am. Chem. Soc., 135 (2013) 18319.

[47] X. Yan, S.Y. Luo, Z.S. Lin, J.Y. Yao, R. He, Y.C. Yue, C.T. Chen, Inorg. Chem., 53 (2014) 1952.

[48] X. Yan, S.Y. Luo, Z.S. Lin, Y.C. Yue, X.Y. Wang, L.J. Liu, C.T. Chen, J. Mater. Chem. C, 1 (2013) 3616.

[49] H.W. Yu, H.P. Wu, S.L. Pan, Z.H. Yang, X.L. Hou, X. Su, Q. Jing, K. R. Poeppelmeier, J. M. Rondinelli, J. Am. Chem. Soc., 136 (2014) 1264.

[50] S.G. Zhao, J. Zhang, S.Q. Zhang, Z.H. Sun, Z.S. Lin, Y.C. Wu, M.C. Hong, J.H. Luo, Inorg. Chem., 53 (2014) 2521.

[51] S.G. Zhao, P.F. Gong, L. Bai, X. Xu, S.Q. Zhang, Z.H. Sun, Z.S. Lin, M.C. Hong, C.T. Chen, J.H. Luo, Nat. Commun., 5 (2014) 4019.

[52] T.T. Tran, N.Z. Koocher, J.M. Rondinelli, P.S. Halasyamani, Angew. Chem. Int. Ed., 56 (2017) 2969.

[53] Y. Yang, S.L. Pan, X.L. Hou, C.Y. Wang, K.R. Poeppelmeier, Z.H. Chen, H.P. Wu, Z.X. Zhou, J. Mater. Chem., 21 (2011) 2890.

[54] Y. Yang, S.L. Pan, H.Y. Li, J. Han, Z.H. Chen, W.W. Zhao, Z.X. Zhou, Inorg. Chem., 50 (2011) 2415.

[55] B.B. Zhang, Z.H. Yang, Y. Yang, M.H. Lee, S.L. Pan, Q. Jing, X. Su, J. Mater. Chem. C, 2 (2014) 4133.

[56] Y. Yang, S.L. Pan, J. Han, X.L. Hou, Z.X. Zhou, W.W. Zhao, Z.H. Chen, M. Zhang, Cryst. Growth Des., 11 (2011) 3912.

[57] L. Li, S.J. Han, B.H. Lei, X.Y. Dong, H.P. Wu, Z.X. Zhou, Z.H. Yang, S.L. Pan, Inorg. Chem., 54 (2015) 7381.

[58] M. Maczka, A. Waskowska, A. Majchrowski, J. Zmija, J. Hanuza, G.A. Peterson, D.A. Keszler, J. Solid State Chem., 180 (2007) 410.

[59] Y. Yang, X. Su, S.L. Pan, Z.H. Yang, Phys. Chem. Chem. Phys., 17 (2015) 26359. 
[60] M.J. Xia, R.K. Li, J. Solid State Chem., 201 (2013) 288.

[61] R.H. Cong, Y. Wang, L. Kang, Z.Y. Zhou, Z.S. Lin, T. Yang, Inorg. Chem. Front., 2 (2015) 170.

[62] S. Guo, X.X. Jiang, L.J. Liu, M.J. Xia, Z. Fang, X.Y. Wang, Z.S. Lin, C.T. Chen, Chem. Mater., 28 (2016) 8871.

[63] H.W. Huang, J.Y. Yao, Z.S. Lin, X.Y. Wang, R. He, W.J. Yao, N.X. Zhai, C.T. Chen, Chem. Mater., 23 (2011) 5457.

[64] S.G. Zhao, L. Kang, Y.G. Shen, X.D. Wang, M.A. Asghar, Z.S. Lin, Y.Y. Xu, S.Y. Zeng, M.C. Hong, J.H. Luo, J. Am. Chem. Soc., 138 (2016) 2961.

[65] H.W. Huang, J.Y. Yao, Z.S. Lin, X.Y. Wang, R. He, W.J. Yao, N.X. Zhai, C.T. Chen, Angew. Chem. Int. Ed., 50 (2011) 9141.

[66] N. Yu, S.C. Wang, N. Ye, F. Liang, Z.S. Lin, M. Luo, K.R. Poeppelmeier, Chem. Mater., 28 (2016) 4563.

[67] S.G. Zhao, P.F. Gong, S.Y. Luo, S.J. Liu, L.N. Li, M.A. Asghar, T. Khan, M.C. Hong, Z.S. Lin, J.H. Luo, J. Am. Chem. Soc., 137 (2015) 2207.

[68] G.S. Yang, P.F. Gong, Z.S. Lin, N. Ye, Chem. Mater., 28 (2016) 9122.

[69] Q. Huang, L.J. Liu, X.Y. Wang, R.K. Li, C.T. Chen, Inorg. Chem., 55 (2016) 12496.

[70] K. Xu, P. Loiseau, G. Aka, J. Cryst. Growth, 311 (2009) 2508.

[71] R.K. Li, Q.D. Zeng, J. Cryst. Growth, 382 (2013) 47.

[72] R.K. Li, P. Chen, Inorg. Chem., 49 (2010) 1561.

[73] J. Zhao, M.J. Xia, R.K. Li, J. Cryst. Growth, 318 (2011) 971.

[74] M.J. Xia, R.K. Li, J. Solid State Chem., 233 (2016) 58.

[75] G.C. Zhang, Z.L. Liu, J.X. Zhang, F.D. Fan, Y.C. Liu, P.Z. Fu, Cryst. Growth Des., 9 (2009) 3137.

[76] H.W. Yu, H.P. Wu, S.L. Pan, Y. Wang, Z.H. Yang, X. Su, Inorg. Chem., 52 (2013) 5359.

[77] G.H. Zou, L.Y. Zhang, N. Ye, CrystEngComm, 2013, 15 (2013) 2422.

[78] G.H. Zou, C.S. Lin, H. Jo, G. Nam, T.S. You, K.M. Ok, Angew. Chem. Int. Ed., 55 (2016) 12078.

[79] J.Z. Fang, K.P. Wang, X.C. Ren, J.X. Zhang, G.C. Zhang, J.Y. Wang, Y.C. Wu, CrystEngComm, 15 (2013) 2972. 
[80] H.W. Yu, S.L. Pan, H.P. Wu, Z.H. Yang, L.Y. Dong, X. Su, B.B. Zhang, H.Y. Li, Cryst. Growth Des., 13 (2013) 3514.

[81] R.K. Li, Y. Yu, Inorg. Chem., 45 (2006) 6840.

[82] J.X. Zhang, S.F. Zhang, Y.C. Wu, J.Y. Wang, Inorg. Chem., 51 (2012) 6682.

[83] M. Wen, X. Su, H.P. Wu, J.J. Lu, Z.H. Yang, S.L. Pan, J. Phys. Chem. C, 120 (2016) 6190.

[84] M. Zhang, S.L. Pan, X.Y. Fan, Z.X. Zhou, K.R. Poeppelmeier, Y. Yang, CrystEngComm, 13 (2011) 2899.

[85] A.G. Al-Ama, E.L. Belokoneva, S.Y. Stefanovich, O.V. Dimitrova, N.N. Mochenova, Crystallogr. Rep., 51 (2006) 225.

[86] M.J. Xia, B. Xu, L.J. Liu, X.Y. Wang, R.K. Li, C.T. Chen, J. Appl. Cryst., 49 (2016) 539.

[87] M.J. Xia, B. Xu, R.K. Li, J. Cryst. Growth, 404 (2014) 65.

[88] M. Zhang, X. Su, S.L. Pan, Z. Wang, H. Zhang, Z.H. Yang, B.B. Zhang, L.Y. Dong, Y. Wang, F.F. Zhang, Y. Yang, J. Phys. Chem. C, 118 (2014) 11849.

[89] E.L. Belokoneva, S.Y. Stefanovich, O.V. Dimitrova, J. Solid State Chem., 195 (2012) 79.

[90] H.P. Wu, S.L. Pan, H.W. Yu, D.Z. Jia, A.M. Chang, H.Y. Li, F.F. Zhang, X. Huang, CrystEngComm, 14 (2012) 799.

[91] H.P. Wu, S.L. Pan, K.R. Poeppelmeier, H.Y. Li, D.Z. Jia, Z.H. Chen, X.Y. Fan, Y. Yang, J.M. Rondinelli, H.S. Luo, J. Am. Chem. Soc., 133 (2011) 7786.

[92] C.Y. Bai, H.W. Yu, S.J. Han, S.L. Pan, B.B. Zhang, Y. Wang, H.P. Wu, Z.H. Yang, Inorg. Chem., 53 (2014) 11213.

[93] S.J. Han, Y. Wang, S.L. Pan, X.Y. Dong, H.P. Wu, J. Han, Y. Yang, H.W. Yu, C.Y. Bai, Cryst. Growth Des., 14 (2014) 1794.

[94] C.D. McMillen, J.T. Stritzinger, J.W. Kolis, Inorg. Chem., 51 (2012) 3953.

[95] H.W. Yu, H.P. Wu, S.L. Pan, Z.H. Yang, X. Su, F.F. Zhang, J. Mater. Chem., 22 (2012) 9665.

[96] H.Y. Li, H.P. Wu, X. Su, H.W. Yu, S.L. Pan, Z.H. Yang, Y. Lu, J. Han, K.R. Poeppelmeier, J. Mater. Chem. C, 2 (2014) 1704.

[97] Z.J. Huang, X. Su, S.L. Pan, X.Y. Dong, S.J. Han, H.W. Yu, M. Zhang, Y. Yang, S.F. Cui, Z.H. Yang, Scr. Mater., 69 (2013) 449.

[98] H.P. Wu, H.W. Yu, Z.H. Yang, X.L. Hou, X. Su, S.L. Pan, K.R. Poeppelmeier, J.M. Rondinelli, J. Am. Chem. Soc., 135 (2013) 4215. 
[99] T. Pilz, M. Jansen, Z. Anorg. Allg. Chem., 637 (2011) 2148.

[100] B.B. Zhang, G.Q. Shi, Z.H. Yang, F.F. Zhang, S.L. Pan, Angew. Chem. Int. Ed., 56 (2017) 3916.

[101] M. Zhang, S.L. Pan, Z.H. Yang, Y. Wang, X. Su, Y. Yang, Z.J. Huang, S.J. Han, K.R. Poeppelmeier, J. Mater. Chem. C, 1 (2013) 4740.

[102] K. Ishihara, K. Nagasawa, K. Umemoto, H. Ito, K. Saito, Inorg. Chem., 33 (1994) 3811.

[103] J. Flanagan, W.P. Griffith, R.D. Powell, A.P. West, J. Chem. Soc., Dalton Trans., (1989) 1651.

[104] M.J. Polinski, S. Wang, E.V. Alekseev, J.N. Cross, W. Depmeier, T.E. Albrecht-Schmitt, Inorg. Chem., 51 (2012) 11541.

[105] J.L. Song, C.L. Hu, X. Xu, F. Kong, J.G. Mao, Inorg. Chem., 52 (2013) 8979.

[106] J.L. Song, X. Xu, C.L. Hu, F. Kong, J.G. Mao, CrystEngComm, 17 (2015) 3953.

[107] C. Wu, L.H. Li, J.L. Song, G. Yang, M.G. Humphrey, C. Zhang, Inorg. Chem. Front., 4 (2017) 692.

[108] X.C. Luo, S.L. Pan, X.Y. Fan, J.D. Wang, G. Liu, J. Cryst. Growth, 311 (2009) 3517.

[109] H.W. Huang, R. He, W.J. Yao, Z.S. Lin, C.T. Chen, Y.H. Zhang, J. Cryst. Growth, 380 (2013) 176.

[110] F. Lin, Y.P. Dong, J.Y. Peng, L.P. Wang, W. Li, B. Yang, Phase Transitions, 89 (2016) 996.

[111] Q. Liu, X.Y. Zhang, Z.H. Yang, F.F. Zhang, L.L. Liu, J. Han, Z. Li, S.L. Pan, Inorg. Chem., 55 (2016) 8744.

[112] Y.Q. Liu, Z.H. Chen, Z.Z. Zhang, Y. Wang, X.Y. Dong, Z.H. Yang, Mater. Res. Bull., 83 (2016) 423.

[113] C. Wu, L.H. Li, J.L. Song, G. Yang, M.G. Humphrey, C. Zhang, Inorg. Chem. 56 (2017) 1340.

[114] Q. Wei, L. Sun, J. Zhang, G.Y. Yang, Dalton Trans., 46 (2017) 7911.

[115] L. Wang, S.L. Pan, L.X. Chang, J.Y. Hu, H.W. Yu, Inorg. Chem., 51 (2012) 1852.

[116] Y.J. Wang, S.L. Pan, X.L. Tian, Z.X. Zhou, G. Liu, J.D. Wang, D.Z. Jia, Inorg. Chem. 48 (2009) 7800.

[117] H.Q. Wu, Q. Wei, H. He, B.F. Yang, Q. Zhang, G.Y. Yang, Inorg. Chem. Commun., 46 (2014) 69.

[118] E.R. Wang, J.H. Huang, S.J. Yu, Y.Z. Lan, J.W. Cheng, G.Y. Yang, Inorg. Chem., 56 (2017) 
6780.

[119] Q. Wei, J.W. Cheng, C. He, G.Y. Yang, Inorg. Chem., 53 (2014) 11757.

[120] F.Y. Zhang, F.F. Zhang, D.Z. Jia, S.L. Pan, Mater. Focus, 4 (2015) 44.

[121] F.Y. Zhang, Q. Jing, F.F. Zhang, S.L. Pan, Z.H. Yang, J. Han, M. Zhang, S.J. Han, J. Mater. Chem. C, 2 (2014) 667.

[122] F.Y. Zhang, F.F. Zhang, J. Qun, S.L. Pan, Z.H. Yang, D.Z. Jia, Phys. Chem. Chem. Phys., 17 (2015) 10489.

[123] J.J. Lu, G.Q. Shi, H.P. Wu, M. Wen, D.W. Hou, Z.H. Yang, F.F. Zhang, S.L. Pan, RSC Adv., 7 (2017) 20259.

[124] C. Wu, J.L. Song, L.H. Li, M.G. Humphrey, C. Zhang, J. Mater. Chem. C, 4 (2016) 8189.

[125] Q. Wei, J.J. Wang, C. He, J.W. Cheng, G.Y. Yang, Chem. Eur. J., 22 (2016) 10759.

[126] L. Cheng, Q. Wei, H.Q. Wu, L.J. Zhou, G.Y. Yang, Chem. Eur. J., 19 (2013) 17662.

[127] D. Zhao, W.D. Cheng, H. Zhang, S.P. Huang, Z. Xie, W.L. Zhang, S.L. Yang, Inorg. Chem., 48 (2009) 6623.

[128] J.H. Jiang, L.C. Zhang, Y.X. Huang, Z.M. Sun, Y.M. Pan, J.X. Mi, Dalton Trans., 46 (2017) 1677.

[129] H.W. Yu , W.G. Zhang, J. Young, J.M. Rondinelli, P.S. Halasyamani, Adv. Mater., 27 (2015) 7380.

[130] H.W. Yu, J. Cantwell, H.P. Wu, W.G. Zhang, K.R. Poeppelmeier, P.S. Halasyamani, Cryst. Growth Des., 16 (2016) 3976.

[131] H.P. Wu, H.W. Yu, S.L. Pan, Z.J. Huang, Z.H. Yang, X. Su, K.R. Poeppelmeier, Angew. Chem. Int. Ed., 52 (2013) 3406.

[132] X.X. Lin, F.F. Zhang, S.L. Pan, H.W. Yu, F.Y. Zhang, X.Y. Dong, S.J. Han, L.Y. Dong, C.Y. Bai, Z. Wang, J. Mater. Chem. C, 2 (2014) 4257.

[133] H. Yang, C.L. Hu, X. Xu, J.G. Mao, Inorg. Chem., 54 (2015) 7516.

[134] M. Luo, G.X. Wang, C.S. Lin, N. Ye, Y.Q. Zhou, W.D. Cheng, Inorg. Chem., 2014, 53 (2014) 8098.

[135] M. Luo, C.S. Lin, G.H. Zou, Ning Ye, W.D. Cheng, CrystEngComm, 16 (2014) 4414.

[136] G.H. Zou, N. Ye, L. Huang, X.S. Lin, J. Am. Chem. Soc., 133 (2011) 20001.

[137] T.T. Tran, J.G. He, J.M. Rondinelli, P.S. Halasyamani, J. Am. Chem. Soc., 137 (2015) 10504. 
[138] T.T. Tran, J. Young, J.M. Rondinelli, P.S. Halasyamani, J. Am. Chem. Soc., 139 (2017) 1285.

[139] M. Luo, Y.X. Song, C.S. Lin, N. Ye, W.D. Cheng, X.F. Long, Chem. Mater., 28 (2016) 2301.

[140] M. Luo, N. Ye, G.H. Zou, C.S. Lin, W.D. Cheng, Chem. Mater., 25 (2013) 3147.

[141] G.S. Yang, G. Peng, N. Ye, J.Y. Wang, M. Luo, T. Yan, Y.Q. Zhou, Chem. Mater., 27 (2015) 7520 .

[142] Y. Lin, C.L. Hu, J.G. Mao, Inorg. Chem., 54 (2015) 10407.

[143] G.H. Zou, G. Nam, H.G. Kim, H. Jo, T.S. You, K.M. Ok, RSC Adv., 5 (2015) 84754.

[144] T.T. Tran, P.S. Halasyamani, J.M. Rondinelli, Inorg. Chem., 53 (2014) 6241.

[145] G.H. Zou, L. Huang, N. Ye, C.S. Lin, W.D. Cheng, H. Huang, J. Am. Chem. Soc., 135 (2013) 18560 .

[146] T.T. Tran, P.S. Halasyamani, Inorg. Chem., 52 (2013) 2466.

[147] L. Huang, G.H. Zou, H.Q. Cai, S.C. Wang, C.S. Lin, N. Ye, J. Mater. Chem. C, 2015, 3 (2015) 5268 .

[148] G.H. Zou, C.S. Lin, H.G. Kim, H. Jo, K.M. Ok, Crystals, 6 (2016) 42.

[149] Y.X. Song, M. Luo, C.S. Lin, N. Ye, Chem. Mater., 29 (2017) 896.

[150] S.M. Grimes, S.R. Johnston, I. Abrahams, J. Chem. Soc., Dalton Trans., 12 (1995) 2081.

[151] G.X. Wang, M. Luo, N. Ye, C.S. Lin, W.D. Cheng, Inorg. Chem., 53 (2014) 5222.

[152] L.X. Chang, L. Wang, X. Su, S.L. Pan, R. Hailili, H.W. Yu, Z.H. Yang, Inorg. Chem., 53 (2014) 3320.

[153] G.X. Wang, M. Luo, C.S. Lin, N. Ye, Y.Q. Zhou, W.D. Cheng, Inorg. Chem., 53 (2014) 12584.

[154] F.C. Zumsteg, J.D. Bierlein, T.E. Gier, J. Appl. Phys., 47 (1976) 4980.

[155] L. Li, Y. Wang, B.H. Lei, S.J. Han, Z.H. Yang, K.R. Poeppelmeier, S.L. Pan, J. Am. Chem. Soc., 138 (2016) 9101.

[156] Y.G. Shen, Y. Yang, S.G. Zhao, B.Q. Zhao, Z.S. Lin, C.M. Ji, L.N. Li, P. Fu, M.C. Hong, J.H. Luo, Chem. Mater., 28 (2016) 7110.

[157] L. Li, Y. Wang, B.H. Lei, S.J. Han, Z.H. Yang, H.Y. Li, S.L. Pan, J. Mater. Chem. C, 5 (2017) 269.

[158] G.P. Han, Q. Liu, Y. Wang, X. Su, Z.H. Yang, S.L. Pan, Phys. Chem. Chem. Phys., 18 (2016) 
19123.

[159] Y.Q. Zhou, L.L. Cao, C.S. Lin, M. Luo, T. Yan, N. Ye, W.D. Cheng, J. Mater. Chem. C, 4 (2016) 9219.

[160] H.W. Yu, J. Young, H.P. Wu, W.G. Zhang, J.M. Rondinelli, P.S. Halasyamani, Chem. Mater., 29 (2017) 1845.

[161] S.G. Zhao, P.F Gong, S.Y. Luo, L. Bai, Z.S. Lin, C.M. Ji, T.L. Chen, M.C. Hong, J.H. Luo, J. Am. Chem. Soc., 136 (2014) 8560.

[162] L. Li, S.J. Han, B.H. Lei, Y. Wang, H.Y. Li, Z.H. Yang, S.L. Pan, Dalton Trans., 45 (2016) 3936 .

[163] Y.G. Shen, S.G. Zhao, B.Q. Zhao, C.M. Ji, L.N. Li, Z.H. Sun, M.C. Hong, J.H. Luo, Inorg. Chem., 55 (2016) 11626.

[164] S.G. Zhao, P.F. Gong, S.Y. Luo, L. Bai, Z.S. Lin, Y.Y. Tang, Y.L. Zhou, M.C. Hong, J.H. Luo, Angew. Chem. Int. Ed., 54 (2015) 4217.

[165] P. Shan, T.Q. Sun, H. Chen, H.D. Liu, S.L. Chen, X.W. Liu, Y.F. Kong, J.J. Xu, Sci. Rep., 6 (2016) 25201.

[166] T.Q. Sun, P. Shan, H. Chen, X.W. Liu, H.D. Liu, S.L. Chen, Y.A. Cao, Y.F. Kong, J.J. Xu, CrystEngComm, 16 (2014) 10497.

[167] P. Shan, T.Q. Sun, H.D. Liu, S.G. Liu, S.L. Chen, X.W. Liu, Y.F. Kong, J.J. Xu, Cryst. Growth Des., 16 (2016) 5588.

[168] M. Abudoureheman, S.J. Han, B.H. Lei, Z.H. Yang, X.F. Long, S.L. Pan, J. Mater. Chem. C, 2016, 4 (2016) 10630.

[169] Y.G. Chen, M.L. Xing, P.F. Liu, Y. Guo, N. Yang, X.M. Zhang, Inorg. Chem., 56 (2017) 845. 
- Recent developments with four major types of UV and deep-UV NLO materials are reviewed.

- Metal borates are reviewed extensively.

- Isoelectronic anions $\left(\mathrm{CO}_{3}\right.$ and $\mathrm{NO}_{3}$ groups) are promising basic units in $\mathrm{UV}$ and deep-UV candidates.

- Metal phosphates possess wide transparency ranges and significant NLO properties.

- Structure-property relationships of these NLO materials are reported. 


\section{Graphical abstract}

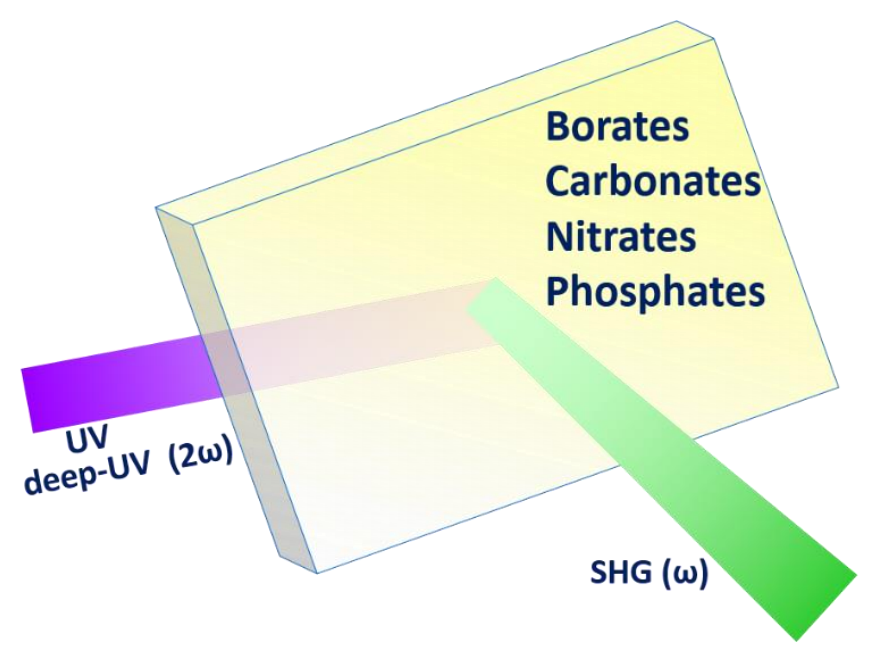

